\title{
Synthesis
}

\section{A new one-pot three-component synthesis of 4-aryl-6-cycloamino-1,3,5-tria- zin-2-amines under microwave irradiation}

Muhammad Syafiq Bin Shahari, Ahmad Junaid, Edward R Tiekink, Anton V Dolzhenko.

Affiliations below.

DOI: $10.1055 / a-1401-2795$

Please cite this article as: Bin Shahari M, Junaid A, Tiekink E R et al. A new one-pot three-component synthesis of 4-aryl-6-cycloamino-1,3,5-triazin-2-amines under microwave irradiation. Synthesis 2021. doi: 10.1055/a-1401-2795

Conflict of Interest: The authors declare that they have no conflict of interest.

This study was supported by Ministry of Higher Education, Malaysia (http://dx.doi.org/10.13039/501100003093), FRGS/1/2020/ STG04/MUSM/02/2

\begin{abstract}
:
A new method for the fast synthesis of diverse 4-aryl-6-cycloamino-1,3,5-triazin-2-amines was developed. The synthesis is performed under microwave irradiation in a one-pot manner from cyanoguanidine, aromatic aldehydes, and cyclic amines. Their three-component reaction in the presence of hydrochloric acid produced dihydrotriazines, which were then converted (without isolation) to the targeted compounds via aromatic dehydrogenation in the presence of alkali. The reaction tolerated various aromatic aldehydes (including heterocyclic) and cyclic amines. Crystal structures of two representative 4-aryl-6-morpholino-1,3,5-triazin-2-amines were established by X-ray crystallography. The results of preliminary biological screening identified potent antileukemic activity for 6-(3,4-dihydroisoquinolin-2(1<i>H</i>)-yl)-4-phenyl-1,3,5-triazin-2-amine.
\end{abstract}

Corresponding Author:

Anton V Dolzhenko, Monash University - Malaysia Campus, School of Pharmacy, Bandar Sunway, Malaysia, anton.dolzhenko@monash. edu, dolzhenkoav@gmail.com

\section{Affiliations:}

Muhammad Syafiq Bin Shahari, Monash University - Malaysia Campus, School of Pharmacy, Bandar Sunway, Malaysia Ahmad Junaid, Purdue University College of Pharmacy Nursing and Health Sciences, Department of Medicinal Chemistry and Molecular Pharmacology, West Lafayette, United States

Edward R Tiekink, Sunway University, Research Centre for Crystalline Materials, Bandar Sunway, Malaysia Anton V Dolzhenko, Monash University - Malaysia Campus, School of Pharmacy, Bandar Sunway, Malaysia Anton V Dolzhenko, Curtin University, School of Pharmacy and Biomedical Sciences, Perth, Australia

This is a PDF file of an unedited manuscript that has been accepted for publication. As a service to our customers we are providing this early version of the manuscript. The manuscript will undergo copyediting, typesetting, and review of the resulting proof before it is published in its final form. Please note that during the production process errors may be discovered which could affect the content, and all legal disclaimers that apply to the journal pertain. 


\section{A New One-Pot Three-component Synthesis of 4-Aryl-6-cycloamino- 1,3,5-triazin-2-amines under Microwave Irradiation}

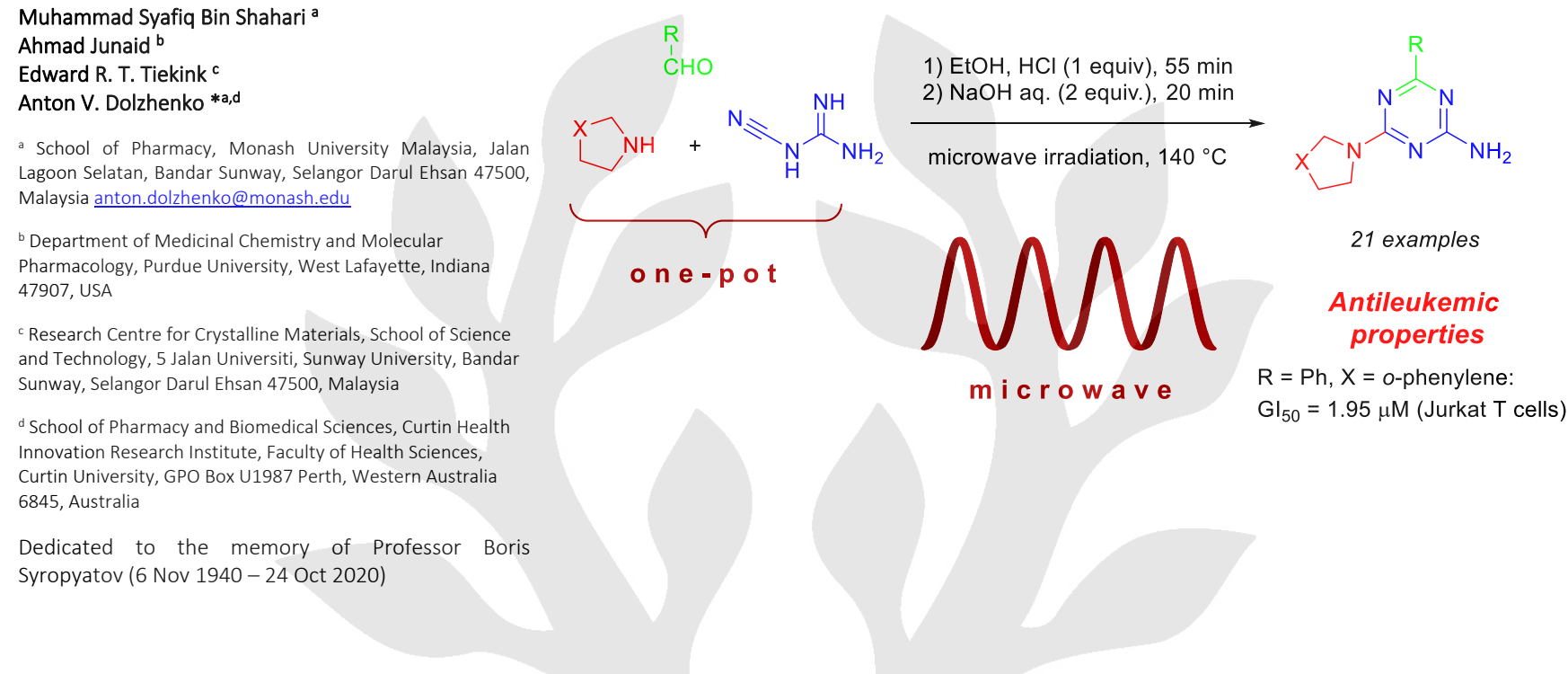

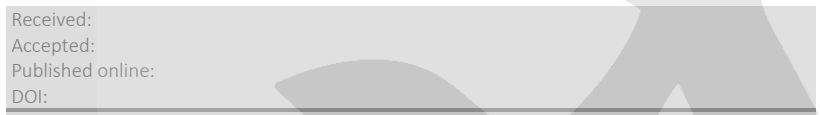

Abstract A new method for the fast synthesis of diverse 4-aryl-6cycloamino-1,3,5-triazin-2-amines was developed. The synthesis is performed under microwave irradiation in a one-pot manner from cyanoguanidine, aromatic aldehydes, and cyclic amines. Their threecomponent reaction in the presence of hydrochloric acid produced dihydrotriazines, which were then converted (without isolation) to the targeted compounds via aromatic dehydrogenation in the presence of alkali. The reaction tolerated various aromatic aldehydes (including heterocyclic) and cyclic amines. Crystal structures of two representative 4aryl-6-morpholino-1,3,5-triazin-2-amines were established by $\mathrm{X}$-ray crystallography. The results of preliminary biological screening identified potent antileukemic activity for 6-(3,4-dihydroisoquinolin-2(1H)-yl)-4phenyl-1,3,5-triazin-2-amine.

Key words Triazines, Multicomponent reactions, Microwave-assisted synthesis, Dehydrogenative aromatization; Antiproliferative activity

1,3,5-Triazines have been one of the most widely used classes of herbicides for the last half-century. ${ }^{1}$ In veterinary medicine, triazines (including 1,3,5-triazines toltrazuril and ponazuril) form a well-established class of antiprotozoal drugs. ${ }^{2}$ In the contemporary design of new bioactive compounds with potential therapeutic applications, the 1,3,5-triazine ring has also proven to be a privileged scaffold. ${ }^{3-5}$ Despite a wide range of biological activities reported for 1,3,5-triazines, achievements in the development of anticancer agents based on this skeleton were particularly important.6,7 Recently approved anticancer drugs include 1,3,5-triazines Enasidenib ${ }^{8,9}$ and Gedatolisibi10,11 (Fig. 1). The 1,3,5-triazine ring of these drugs is decorated in positions 2,4 , and 6 with two substituted amino groups and a (het)aryl moiety. The inhibitors of
Bruton's tyrosine kinase ${ }^{12}$ and lysophosphatidic acid acyltransferase $\beta^{13-15}$ and recently reported ${ }^{16}$ highly potent and selective agents targeting triple-negative breast cancer share a similar 4-(het)aryl-6-arylamino-1,3,5-triazin-2-amine scaffold. Structurally related compounds with 6-aralkylamino substitution demonstrated potent inhibition of tryptophan hydroxylase ${ }^{17}$ and an effective positive allosteric modulation of G protein-coupled receptor 68 (GPR68).18,19 The inhibitors of phosphoinositide 3-kinase ${ }^{20}$ and ligands for $\mathrm{H}_{4}$ histamine receptors ${ }^{21,22}$ were found among 4-aryl-6-cycloamino-1,3,5triazin-2-amines, while similar 4-aralkyl-6-cycloamino-1,3,5triazin-2-amines selectively bound to $5-\mathrm{HT}_{6}$ serotonin receptors. ${ }^{23}$

The pharmacological investigation of 4-aryl-6-cycloamino1,3,5-triazin-2-amines (1) possessing different substitution patterns would open opportunities for the identification of new potent bioactive agents. However, existing methods for the preparation of these compounds are limited and do not allow fast synthesis of sufficiently diverse molecules.

One of the methods for the synthesis of 4-aryl-6-cycloamino1,3,5-triazin-2-amines (1) utilizes cyanuric chloride, which is involved in a sequential nucleophilic substitution with cyclic amines (e.g. morpholine) and then ammonia; the Suzuki crosscoupling of the resulting intermediate with arylboronic acids concludes this approach (Scheme 1, Route 1).20

Another general approach for the synthesis of $\mathbf{1}$ relies on the reactions of biguanides, derived from cyanoguanidine and cyclic amines, with different reagents (Route 2). The reaction of biguanides with benzoin is highly sensitive to $\mathrm{pH}$ and structure substrates ${ }^{24}$ making the scope of this method for the preparation of 4-aryl-6-cycloamino-1,3,5-triazin-2-amines 
limited. The condensation of biguanides with carboxylic acid derivatives, e.g. esters in the presence of strong bases, is the most common method for the synthesis of 1.25 Recently, $\mathrm{N}, \mathrm{N}$ dimethyl-substituted amides were employed in the imidazolium-catalyzed reaction with biguanides resulting in the triazine ring closure. 26 However, this reaction was more applicable to DMF as a one-carbon inserting synthon and only one 4-aryl derivative was prepared by this method. ${ }^{26}$ Benzyl alcohols were reported to react with biguanides under the ruthenium ${ }^{27}$ or graphene oxide ${ }^{28}$ catalysis affording 4-aryl-6cycloamino-1,3,5-triazin-2-amines (1). Being more general in scope, these methods suffer from relatively long reaction time (heating for up to $30 \mathrm{~h}$ in the second step).

Recently, we developed a new method for the synthesis of $6, N^{2}$ diaryl-1,3,5-triazin-2,4-diamines (3) via one-pot threecomponent condensation, followed by the Dimroth rearrangement and dehydrogenative aromatization of the dihydrotriazine intermediate $\mathbf{2}$ (Scheme 2). ${ }^{29}$ This method was efficiently applied to a wide range of substrates and afforded compounds with significant anticancer activity. ${ }^{30}$ The three- component synthesis of dihydrotriazines $\mathbf{4}$ has not been reported. Moreover, secondary amines and all aliphatic amines failed to afford dihydrotriazines in earlier attempts ${ }^{31}$ to involve them in the three-component reaction with cyanoguanidine and aldehydes. Nevertheless, we decided to attempt performing the three-component synthesis of $\mathbf{4}$ under microwave irradiation also suggesting that upon heating in the presence of a base, these intermediate would undergo dehydrogenative aromatization to afford the desired triazines 1 (Scheme 2). Performing both of these transformations in a one-pot manner would make this method more practical for the fast synthesis of diverse 4-aryl-6-cycloamino-1,3,5-triazin2-amines (1). Microwave irradiation has demonstrated a great utility in the multicomponent reactions ${ }^{32}$ and for the preparation of 1,3,5-triazines ${ }^{33}$ improving the efficiency of synthetic procedures. Herein we report the development of a new method for the synthesis of 4-aryl-6-cycloamino-1,3,5triazin-2-amines (1) via the proposed approach under microwave irradiation.

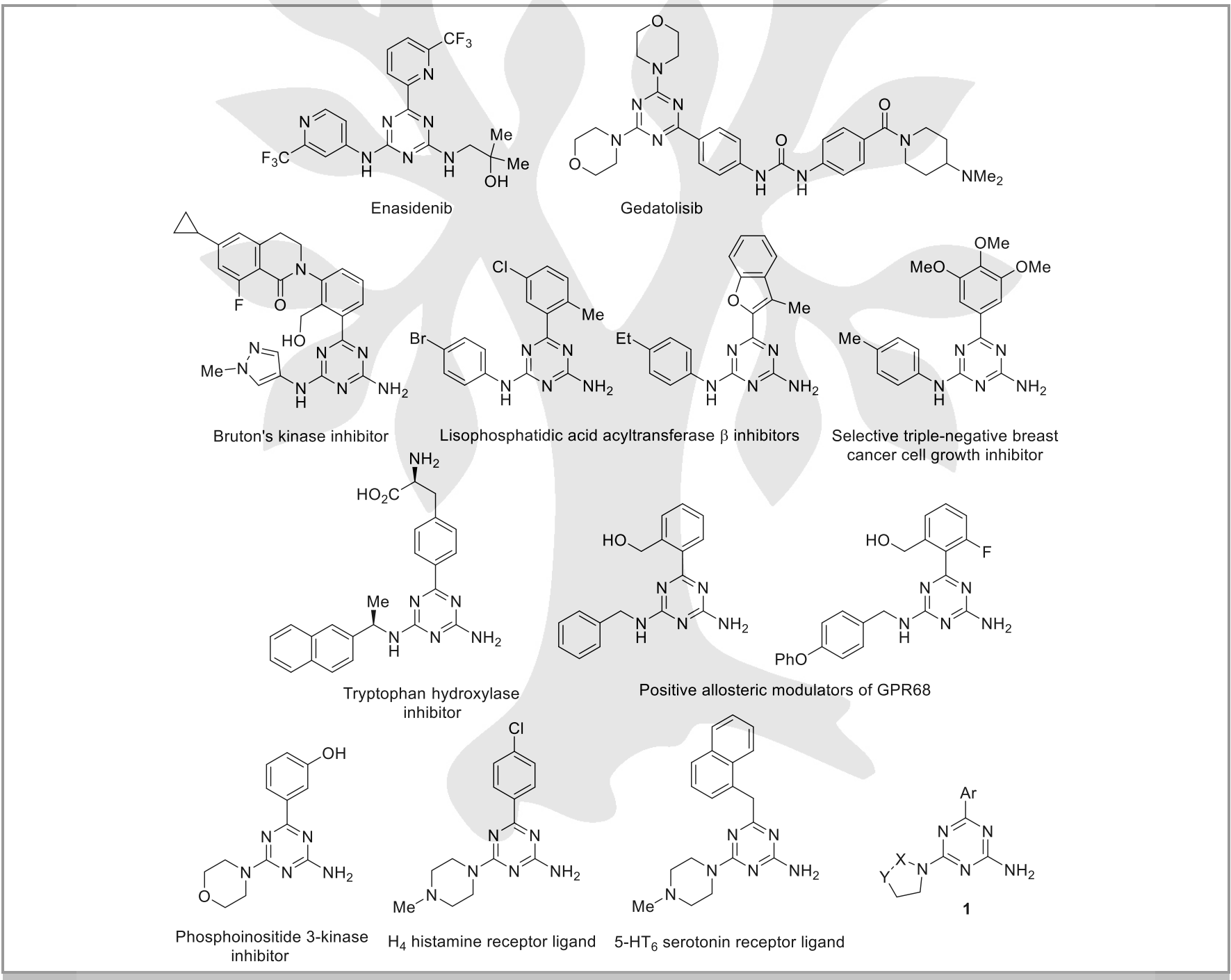

Figure 1 Selected bioactive 1,3,5-triazines. 


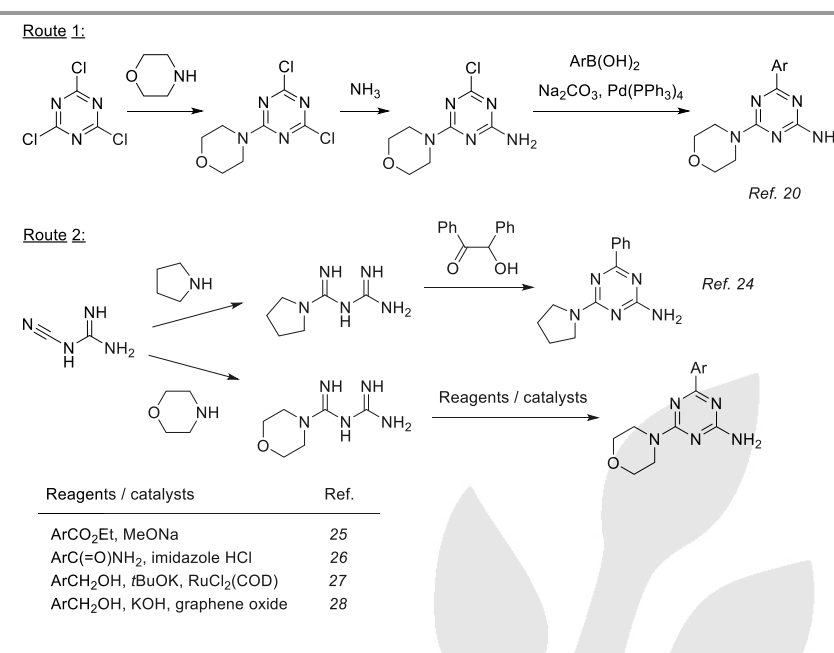

Scheme 1 Reported methods for the synthesis of 4-aryl-6-cycloamino-1,3,5triazin-2-amines.

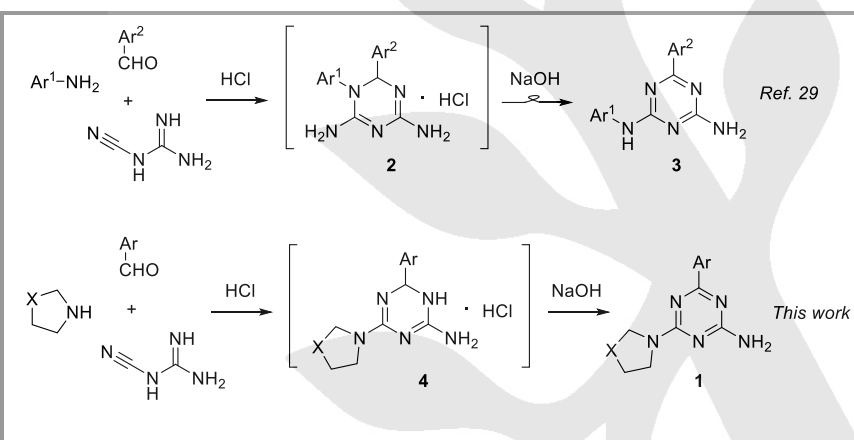

Scheme 2 One-pot three-component synthesis of $6, N^{2}$-diaryl-1,3,5-triazin2,4-diamines (3) and proposed synthesis of 4-aryl-6-cycloamino-1,3,5-triazin2-amines (1).

For the trial reaction and the subsequent condition optimization, we utilized the model reaction of cyanoguanidine with $p$-tolualdehyde and morpholine under controlled microwave irradiation in a Monowave 400 reactor (Anton Paar, Austria) (Table 1). Replicating the reaction conditions from our protocol developed earlier for the synthesis of 6, $N^{2}$-diaryl-1,3,5triazin-2,4-diamines (3), ${ }^{29}$ we were delighted to observe the formation of desired product 1f, which was easily isolated by simple filtration in 37\% yield (Table 1, entry 2). Changing the solvent from $\mathrm{EtOH}$ to $\mathrm{MeOH}$ or $\mathrm{PrOH}$ resulted in lower yields (entries 1 and 3). Attempts to increase or decrease the reaction temperature also had a negative impact on yields of $\mathbf{1 f}$ (entries 4 and 5) and further optimization was continued at $140{ }^{\circ} \mathrm{C}$ using $\mathrm{EtOH}$ as a reaction medium. It was found that an increase in the duration of the first step benefited the reaction outcome improving the yield to $44 \%$ in 55 min (entry 6). Further improvement to $48 \%$ yield was achieved extending the duration of the second step to 20 min (entry 7). The longer duration of the second step resulted in lower yields, probably due to the gradual degradation of the product under the reaction conditions (entry 8 and 9). The addition of another equivalent of $p$-tolualdehyde at any of the steps did not improve the reaction outcome (entries 10 and 11 ). At the same time, the base appeared to play a critical role in the second step. The detrimental effect to the reaction outcome was observed when sodium hydroxide was applied in the second step in the quantity equimolar to hydrochloric acid added in the first step (entry 12). Heating without microwave irradiation under otherwise similar conditions using a Monowave 50 reactor resulted in some decrease in the yield of $\mathbf{1 f}$ (entry 13). Therefore, microwave conditions allowing isolation of $\mathbf{1 f}$ in $48 \%$ yield (entry 7) were used for the exploration of the reaction scope (more detailed optimization results are available in Supporting Information Table S1). It should be also noted that unlike in the synthesis of $N^{2}$-aryl analogs of 4,34 we were unable to isolate intermediate $\mathbf{4}$ after the first step.

Table 1 Optimization of reaction conditions for the synthesis of 4-(4methylphenyl)-6-morpholino-1,3,5-triazin-2-amine (1f) under microwave irradiation. $^{a}$

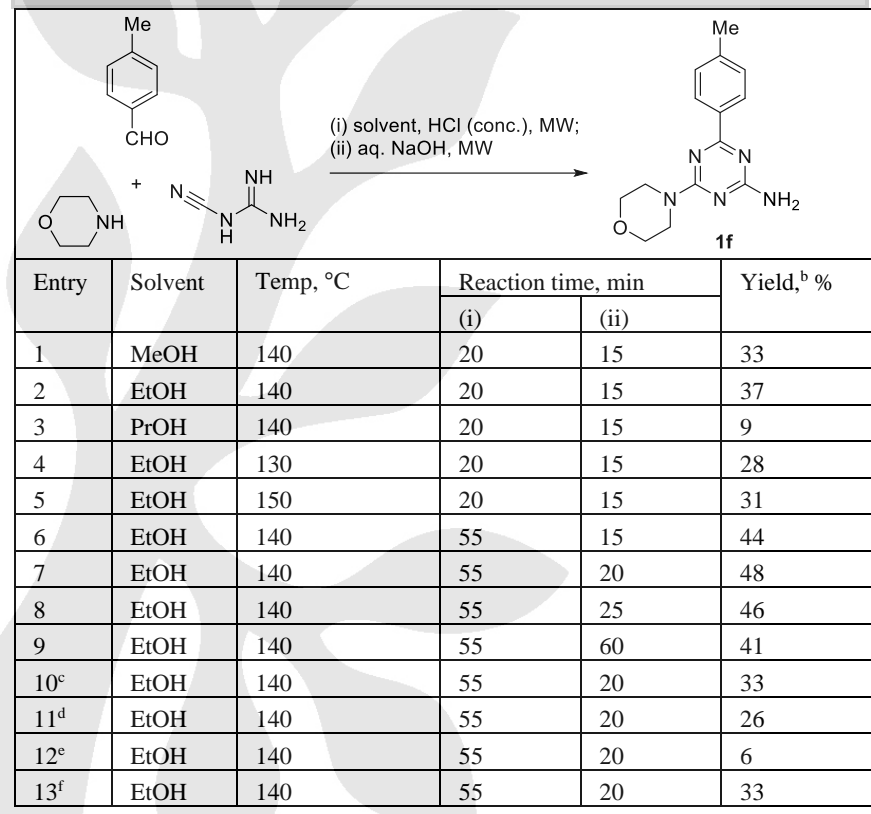

a The reactions were performed in a Monowave 400 microwave reactor (Anton Paar, Austria) using cyanoguanidine $(2.5 \mathrm{mmol}), p$-tolualdehyde $(2.5 \mathrm{mmol})$, morpholine $(2.5 \mathrm{mmol})$, and conc. $\mathrm{HCl}(2.5 \mathrm{mmol})$ in $2 \mathrm{~mL}$ of the specified solvent in step (i) and addition of $1 \mathrm{~mL}$ of $5 \mathrm{~N} \mathrm{NaOH}$ (aq.) in step (ii).

b Isolated yield calculated on the basis of cyanoguanidine.

c The reaction was carried out using $5 \mathrm{mmol}$ of $p$-tolualdehyde.

${ }^{\mathrm{d}}$ Another $2.5 \mathrm{mmol}$ of $p$-tolualdehyde was added to the reaction mixture in step (ii).

e $0.5 \mathrm{~mL}$ of $5 \mathrm{~N} \mathrm{NaOH}$ (aq.) [2.5 mmol] was used in step (ii).

${ }^{\mathrm{f}}$ The reaction was performed in a Monowave 50 reactor (Anton Paar, Austria) without microwave irradiation.

In the exploration of the method scope, different aromatic aldehydes and cyclic amines were examined. The reaction of cyanoguanidine and morpholine with benzaldehydes tolerated various substituents in the aldehyde aromatic ring (Scheme 3). Moreover, heteroaromatic thenaldehyde was also successfully involved in the reaction affording $1 p$ in $53 \%$ yield.

Examining the scope of cyclic amines for the reaction, we found that in the three-component reaction with cyanoguanidine and benzaldehyde, morpholine could be replaced by pyrrolidine, piperidines, $N$-methylpiperazine, or tetrahydroisoquinoline thus affording corresponding 6-cycloamino-4-phenyl-1,3,5-triazin-2amines (1q-u) (Scheme 4). 


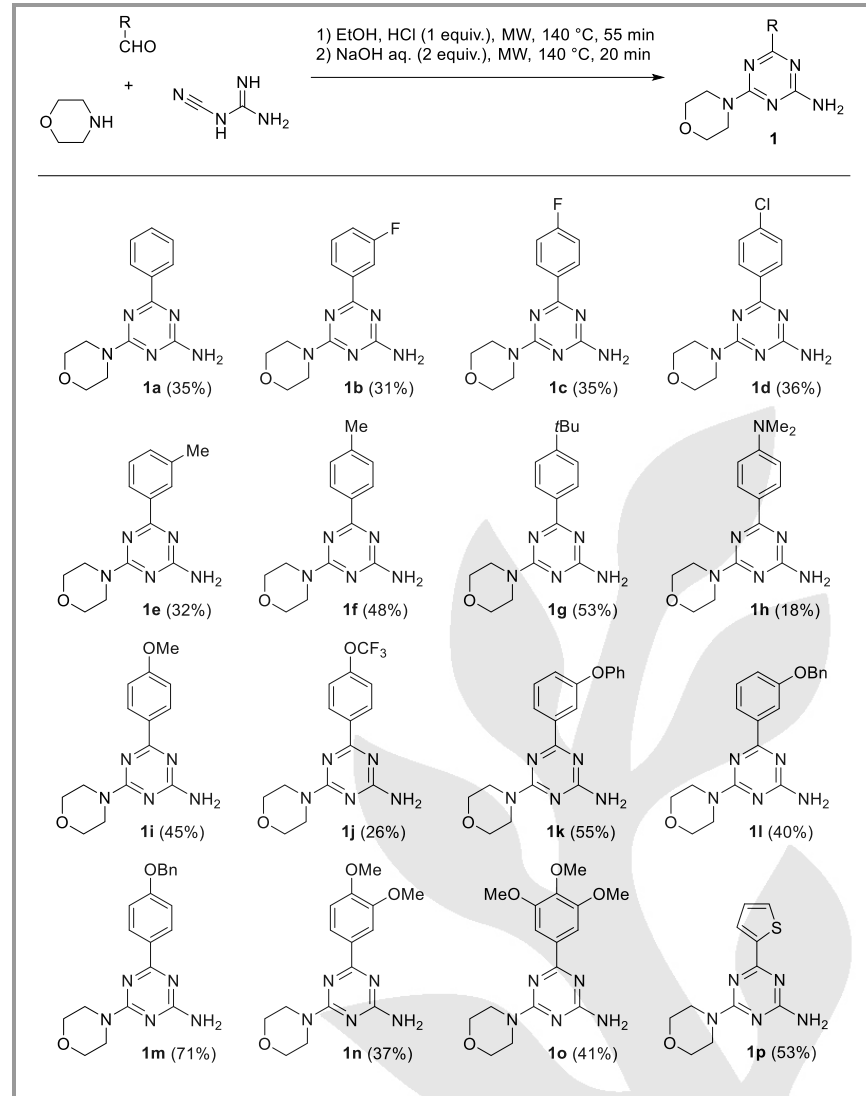

Scheme 3 Scope of aromatic aldehydes for the synthesis of 4-aryl-6morpholino-1,3,5-triazin-2-amines (1a-p).

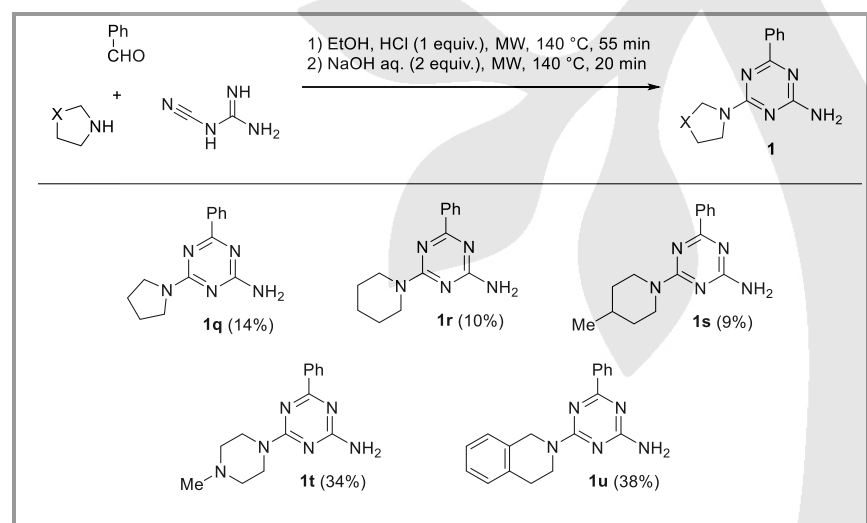

Scheme 4 Scope of cyclic amines for the synthesis of 4-phenyl-6-cycloamino1,3,5-triazin-2-amines (1q-u).

The proposed mechanism for the synthesis of $\mathbf{1}$ is outlined in Scheme 5. In the first step, the addition of a cyclic amine to the acid-activated nitrile group of cyanoguanidine is followed by the reaction of the formed biguanide $\mathbf{5}$ with an aldehyde resulting in the dihydrotriazine ring closure and formation of the intermediate 4. In the presence of alkali, it converts to the $\mathrm{N}$ Mannich base 6, which undergoes dehydrogenative aromatization resulting in the formation of $\mathbf{1}$. It is proposed that the aromatization involves initial ring-opening by the alkali, oxidation to the $\mathrm{N}$-acylbiganide 7 , recyclization to $\mathbf{8}$, and subsequent dehydration affording the desired product $\mathbf{1}$.

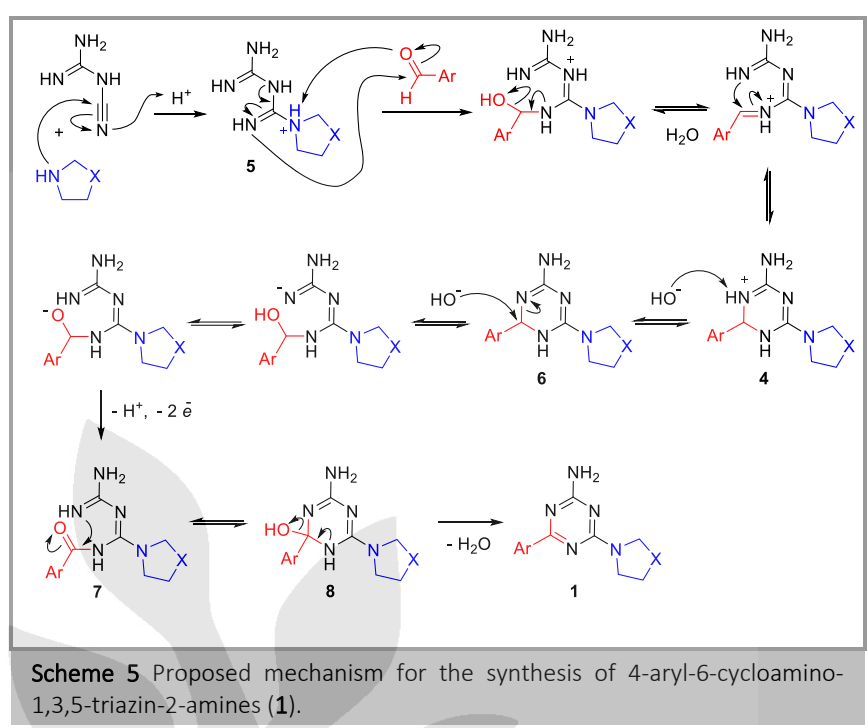

The NMR spectroscopic data for the prepared compounds support proposed structure $\mathbf{1}$. In the ${ }^{13} \mathrm{C}$ NMR spectra of $\mathbf{1}$, the three downfield signals at 164.4-169.7 ppm confirm the formation of an electron-deficient aromatic 1,3,5-triazine ring.

Due to extended conjugation, the triazine and a phenyl ring directly attached to it are coplanar. This results in a significant downfield shift of the ${ }^{1} \mathrm{H}$ NMR spectra signals attributed to phenyl protons located in ortho-positions to the triazine and experiencing its anisotropic effect.

The electron-deficient nature of the triazine ring results in significant delocalization of electrons from the adjacent amino groups. The protons of the primary amino group in position 2 are therefore deshielded and their signal in ${ }^{1} \mathrm{H}$ NMR spectra appear at 6.71-7.01 ppm. The electron delocalization of the cycloamino nitrogen atom is particularly visible in the NMR spectra of 1q, which possesses a relatively more rigid pyrrolidine ring. This delocalization implies a partial double bond character of the $\mathrm{C}-\mathrm{N}$ bond connecting the rings. In ${ }^{1} \mathrm{H}$ and ${ }^{13} \mathrm{C}$ NMR spectra of $\mathbf{1 q}$, the restricted rotation around this bond manifests in individual signals for magnetically non-equivalent atoms of the opposite sides of the symmetrical pyrrolidine ring.

The ${ }^{1} \mathrm{H}$ NMR spectrum of $1 \mathrm{~s}$ also confirms the substantial delocalization of the lone pair of the piperidine nitrogen over the triazine ring. The methyl group in position 4 of the piperidine ring stabilizes its chair conformation with substituents occupying equatorial positions. The chemical shifts and coupling for the signals of the remaining protons also confirm the chair conformation of the piperidine ${ }^{35}$ in $\mathbf{1 s .}$ Additionally, the equatorial protons at carbon atoms adjacent to the piperidine nitrogen occur in the plane of the triazine ring and due to restricted rotation become magnetically nonequivalent. Therefore, in the ${ }^{1} \mathrm{H}$ NMR spectrum of 1s, these protons give two independent signals downfield-shifted to 4.72$4.81 \mathrm{ppm}(\Delta \delta \approx 1.7-1.8 \mathrm{ppm}$ from the signals of the same protons in 4-methylpiperidine ${ }^{36}$ ) due to the anisotropic effect of the triazine ring. The axial protons at the same carbon atoms are affected significantly less $(\Delta \delta \approx 0.3 \mathrm{ppm})$. At higher temperatures $\left(35^{\circ} \mathrm{C}\right)$, two broad signals of the equatorial $\alpha$ - $\mathrm{CH}$ coalesce into a single peak still suggesting slow rotation around the $\mathrm{C}-\mathrm{N}$ bond between the triazine and piperidine rings due to the lone pair 
delocalization (Fig. 2). Upon further heating, the signal the equatorial $\alpha-\mathrm{CH}$ transforms into the expected doublet with ${ }^{2} J_{\mathrm{gem}}=-13 \mathrm{~Hz}$. Due to the 1,4-substitution of the piperidine ring in $\mathbf{1 s}$, its chair conformation remains stable at these temperatures.

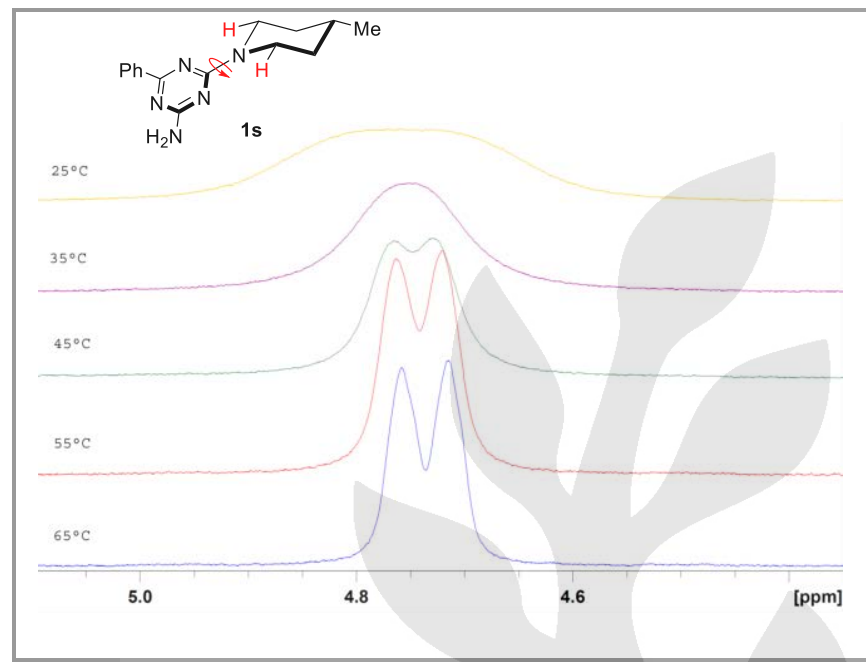

Figure 2 Restricted rotation around the $\mathrm{C}-\mathrm{N}$ bond between the triazine and piperidine rings in $1 \mathrm{~s}$ : signals of the equatorial $\alpha-\mathrm{CH}$ of piperidine in dynamic ${ }^{1} \mathrm{H}$ NMR spectra.

The structural assignments were further confirmed by X-ray crystallography data for two representative compounds $\mathbf{1 l}$ and 1n; their molecular structures are illustrated in Fig. 3. In 11, the six atoms comprising the triazine ring are planar, exhibiting a r.m.s. deviation $=0.0074 \AA$. The pendent phenyl ring is inclined to the central plane $\left[\mathrm{N} 3 \mathrm{C} 3 / \mathrm{C} 6\right.$ dihedral angle $\left.=26.77(5)^{\circ}\right]$ and the dihedral angle between the triazine ring and the best plane through the morpholine ring (chair conformation) of $5.89(7)^{\circ}$ is indicative of approximately co-planar relationship. The (benzyloxy)phenyl residue is twisted as seen in the dihedral angle between the rings of $79.47(4)^{\circ}$. The terminal ring lies in a position orientated towards the bay region of the molecule defined by the triazine and two connected rings, and is orthogonal to the central plane forming a dihedral angle of $88.80(3)^{\circ}$. Within the ring, the $\mathrm{C}-\mathrm{N}$ bond lengths span a relatively narrow range, i.e. 1.3293(14) $\AA$ for C4-N5 to $1.3546(14) \AA$ for $\mathrm{C} 2-\mathrm{N} 3$, consistent with considerable delocalization of $\pi$-electron density over the ring; the exocyclic C2-N2 bond [1.3429(14) Å] lies within this range.

The molecular structure of $\mathbf{1 n}$, Fig. 3(b), presents similar features to that of $\mathbf{1 1}$. The r.m.s. deviation for the six atoms comprising triazine ring $=0.0090 \AA$. The dihedral angles between the central plane and the attached phenyl $\left[11.28(5)^{\circ}\right]$ and morpholine [5.10 $(5)^{\circ}$; chair conformation] rings indicate, to a first approximation, co-planar relationships. The molecule has the shape of the letter, U. Within the triazine ring, significant delocalization of $\pi$-electron density is indicated as the range of C-N bond lengths is less than for 1l, i.e. 1.3318(16) A for C4-N3 to $1.3529(16) \AA$ for $\mathrm{C} 2-\mathrm{N} 3$, and, again, as for $\mathbf{1 1}$, there is no pattern of alternating short and long $\mathrm{C}-\mathrm{N}$ bonds within the triazine ring; the C2-N2 bond length is $1.3366(16) \AA$.

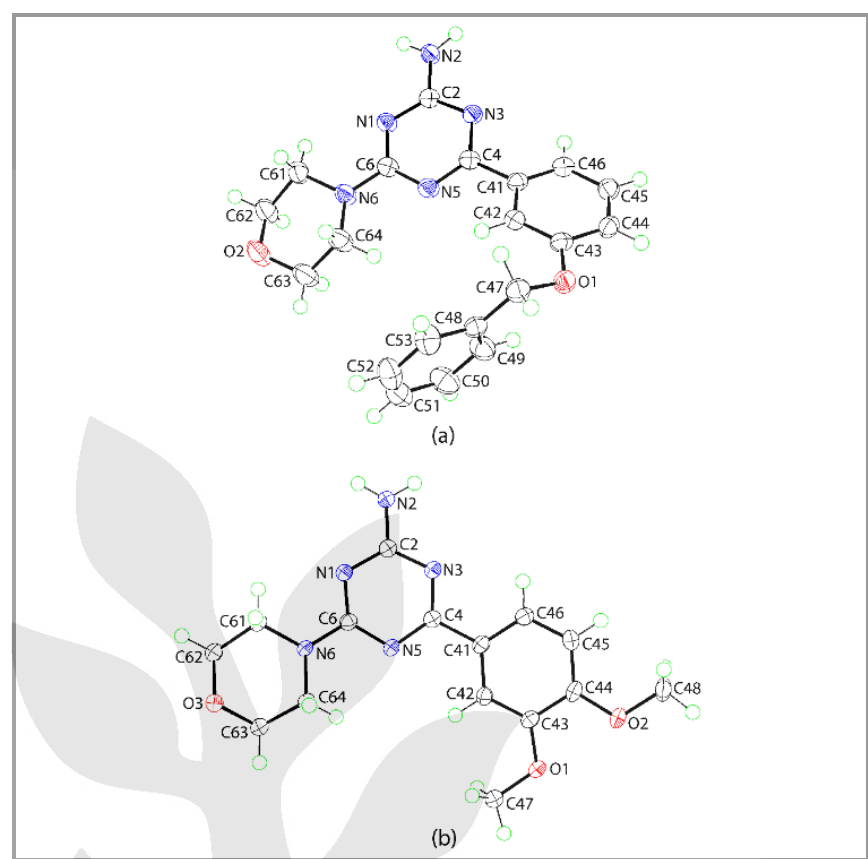

Figure 3 Molecular structures of (a) 1 ll and (b) 1 n showing atom labeling scheme and $70 \%$ anisotropic displacement parameters.

In the molecular packing of $\mathbf{1} \mathbf{l}$, amine- $\mathrm{N}-\mathrm{H} \cdots \mathrm{N}$ (triazine) hydrogen bonding assembles centrosymmetrically-related molecules into dimeric aggregates through eight-membered $\{\cdots \text { HNCN }\}_{2}$ supramolecular synthons, Fig. 4(a); geometric parameters characterizing the key interatomic contacts are given in the caption of Supporting Information Fig. S1. The aggregates thus formed are linked into a supramolecular tape, approximately along [ $\left[\begin{array}{lll}1 & 3 & 0\end{array}\right]$, by amine- $\mathrm{N}-\mathrm{H} \cdots \mathrm{O}$ (ether) hydrogen bonds. The connections between tapes to form a layer in the abplane are $\pi$-stacking interactions between triazine and C41phenyl rings as detailed in Supporting Information Fig. S1; layers stack along the c-axis without directional interactions between them.

A more complicated expansion of supramolecular association is evident in the crystal of $\mathbf{1 n}$ whereby each molecule is connected to four symmetry-related molecules by conventional hydrogen bonding. Thus, the hydrogen bonds prominent in the molecular packing are amine- $\mathrm{N}-\mathrm{H} \cdots \mathrm{O}$ (morpholine) and amine-N$\mathrm{H} \cdots \mathrm{N}($ triazine), and lead to the formation of a two-dimensional array in the ac-plane, Fig. 4(b); see the caption of Supporting Information Fig. S2 for geometric details. Additional stabilization to the layer is afforded by morpholine-C$\mathrm{H} \cdots \mathrm{O}$ (methoxy) and morpholine- $\mathrm{C}-\mathrm{H} \cdots \pi$ (phenyl) contacts. The layers stack along the $\mathrm{b}$-axis with the directional interactions to consolidate the three-dimensional packing being methyl-C$\mathrm{H} \cdots \mathrm{O}$ (methoxy) and $\pi$-stacking interactions between triazine and C41-phenyl rings; a view of the unit-cell contents is shown in Supporting Information Fig. S2. 


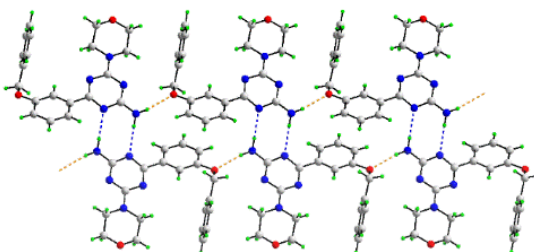

(a)

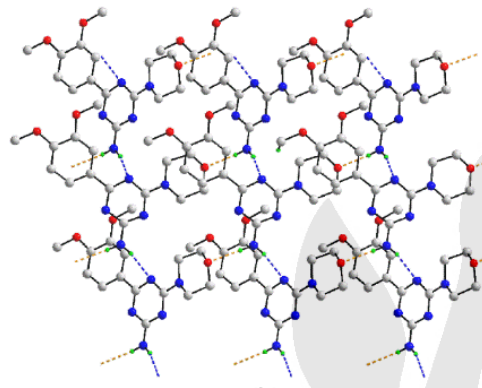

(b)

Figure 4 Supramolecular association sustained by conventional hydrogen bonds in $1 \mathrm{l}$ and $1 \mathrm{n}$ : (a) the supramolecular tape in the crystal of $\mathbf{1 l}$ and (b) supramolecular layer in the crystal of 1 (non-participating hydrogen atoms have been omitted for clarity). The $\mathrm{N}-\mathrm{H} \cdots \mathrm{O}$ and $\mathrm{N}-\mathrm{H} \cdots \mathrm{N}$ hydrogen bonds are represented by orange and blue dashed lines, respectively.

The prepared compounds were screened for antiproliferative activity against a Jurkat-T cell line at $10 \mu \mathrm{M}$. The most potent compound identified in the screening was 6-(3,4dihydroisoquinolin-2(1H)-yl)-4-phenyl-1,3,5-triazin-2-amine

(1u), which was further tested at several concentrations (Supporting Information, Fig. S3) to estimate the 50\% growth inhibition $\left(\mathrm{GI}_{50}\right)$ value. Typical antileukemic drugs mercaptopurine, methotrexate, and cytarabine were used as positive controls. It was found that $\mathbf{1} \mathbf{u}$ inhibited cell proliferation in a concentration-dependent manner demonstrating the $\mathrm{GI}_{50}$ value of $1.95 \pm 0.25 \mu \mathrm{M}$. Being more potent than mercaptopurine $\left(\mathrm{GI}_{50}=11.12 \pm 4.89 \mu \mathrm{M}\right), \mathbf{1} \mathbf{u}$ was less effective than methotrexate $\left(\mathrm{GI}_{50}=0.37 \pm 0.03 \mu \mathrm{M}\right)$ and cytarabine $\left(\mathrm{GI}_{50}=0.29 \pm 0.01 \mu \mathrm{M}\right)$. Nevertheless, these results indicate that the search for new antileukemic agents among 4aryl-6-cycloamino-1,3,5-triazin-2-amines could be fruitful.

In conclusion, we developed a new method for the fast one-pot synthesis of diverse 4-aryl-6-cycloamino-1,3,5-triazin-2-amines. This method is based on two processes: (1) acid-catalyzed three-component condensation of cyanoguanidine, aromatic aldehydes, and cyclic amines and (2) dehydrogenative aromatization in the presence of a base. Overall, the method was found to be rather general, with similar efficacy applicable to various aldehydes and cyclic amines. The main advantage of the method is the potential for quick and convenient access to structurally diverse 4-aryl-6-cycloamino-1,3,5-triazin-2-amines for their biological evaluations. Preliminary data from the antileukemic screening of prepared 4-aryl-6-cycloamino-1,3,5triazin-2-amines were promising. Further investigations are under way and the results will be reported in due course.

The experimental section has no title; please leave this line here

\section{General information}

Melting points (uncorrected) were determined on a Stuart ${ }^{\mathrm{TM}} \mathrm{SMP} 40$ automatic melting point apparatus. ${ }^{1} \mathrm{H}$ and ${ }^{13} \mathrm{C}$ NMR spectra were recorded on a Bruker Fourier NMR spectrometer (300 MHz) using
DMSO- $d_{6}$ as a solvent and TMS as an internal reference. Microwaveassisted reactions were carried out in the closed vessel focused single mode using a Monowave 400 microwave synthesizer (Anton Paar, Austria) monitoring reaction temperature by the equipped IR sensor. The control experiment using conventional heating was performed in a Monowave 50 (Anton Paar, Austria) reactor.

General procedure for the preparation of 4-aryl-6-cycloamino1,3,5-triazin-2-amines (1).

To a solution of cyanoguanidine $(0.21 \mathrm{~g}, 2.5 \mathrm{mmol})$, (het)arylaldehyde $(2.5 \mathrm{mmol})$ and cyclic amine $(2.5 \mathrm{mmol})$ in EtOH $(2 \mathrm{~mL})$ in a $10 \mathrm{~mL}$ seamless pressure vial, conc. $\mathrm{HCl}(0.21 \mathrm{~mL}, 2.5 \mathrm{mmol})$ was added. The reaction mixture was irradiated in the Monowave 400 (Anton Paar, Austria) microwave reactor operating at maximal microwave power up to $850 \mathrm{~W}$ at $140{ }^{\circ} \mathrm{C}$ for $55 \mathrm{~min}$. After cooling to rt, an aq. solution of $\mathrm{NaOH}$ $(5 \mathrm{~N}, 1 \mathrm{~mL})$ was added to the reaction mixture and irradiation continued for another $20 \mathrm{~min}$ at $140{ }^{\circ} \mathrm{C}$. After cooling, the precipitated product was filtered, washed with water and recrystallized from an appropriate solvent affording desired products 1

6-Morpholino-4-phenyl-1,3,5-triazin-2-amine (1a).

White solid; yield $224 \mathrm{mg}$ (35\%); mp 119-121 ${ }^{\circ} \mathrm{C}$ (EtOH), lit. ${ }^{37} 121-123$ ${ }^{\circ} \mathrm{C}$. ${ }^{1} \mathrm{H}$ NMR (300 MHz, DMSO- $\left.d_{6}\right): \delta 3.63-3.67\left(4 \mathrm{H}, m, \mathrm{CH}_{2} \mathrm{OCH}_{2}\right), 3.80$ $\left(4 \mathrm{H}, b r s, \mathrm{CH}_{2} \mathrm{NCH}_{2}\right), 6.94\left(2 \mathrm{H}, b r s, \mathrm{NH}_{2}\right), 7.43-7.55\left(3 \mathrm{H}, m, \mathrm{H}-3^{\prime}, \mathrm{H}-4^{\prime}\right.$, and $\mathrm{H}-5^{\prime}$ ), 8.28-8.32 (2H, $m, \mathrm{H}-2^{\prime}$ and $\mathrm{H}-6^{\prime}$ ). ${ }^{13} \mathrm{C}$ NMR (75 MHz, DMSO- $d_{6}$ ): $\delta$ $43.1\left(\mathrm{CH}_{2} \mathrm{NCH}_{2}\right), 65.9\left(\mathrm{CH}_{2} \mathrm{OCH}_{2}\right), 127.7$ (2C), 128.1 (2C), 131.2, 136.8, 164.9 (C-6), 167.1 (C-2), 169.6 (C-4). Anal. Calcd for $\mathrm{C}_{13} \mathrm{H}_{15} \mathrm{~N}_{5} \mathrm{O}$ : C, 60.69; H, 5.88; N, 27.22. Found: C, 60.54; H, 5.93; N, 27.07.

\section{4-(3-Fluorophenyl)-6-morpholino-1,3,5-triazin-2-amine (1b).}

White solid; yield $215 \mathrm{mg}$ (31\%); mp 143-144 ${ }^{\circ} \mathrm{C}$ (EtOH). ${ }^{1} \mathrm{H}$ NMR (300 MHz, DMSO-d $d_{6}$ : $\delta 3.63-3.68\left(4 \mathrm{H}, m, \mathrm{CH}_{2} \mathrm{OCH}_{2}\right), 3.80\left(4 \mathrm{H}\right.$, br $s, \mathrm{CH}_{2} \mathrm{NCH}_{2}$ ), $7.03\left(2 \mathrm{H}, b r s, \mathrm{NH}_{2}\right), 7.37\left(1 \mathrm{H}, d d t, J=0.9,2.7,8.5 \mathrm{~Hz}, \mathrm{H}-4^{\prime}\right), 7.53(1 \mathrm{H}, d d d$, $\left.J=6.0,8.0,8.0 \mathrm{~Hz}, \mathrm{H}-5^{\prime}\right), 8.01\left(1 \mathrm{H}, d d d, J=1.4,2.7,10.6 \mathrm{~Hz}, \mathrm{H}-2^{\prime}\right), 8.14$ $\left(1 \mathrm{H}, d d d, J=1.2,1.2,7.8 \mathrm{~Hz}, \mathrm{H}-6{ }^{\prime}\right) .{ }^{13} \mathrm{C}$ NMR $\left(75 \mathrm{MHz}, \mathrm{DMSO}-d_{6}\right): \delta 43.1$ $\left(\mathrm{CH}_{2} \mathrm{NCH}_{2}\right), 65.9\left(\mathrm{CH}_{2} \mathrm{OCH}_{2}\right), 114.0(d, J=22.9 \mathrm{~Hz}), 118.0(d, J=21.1 \mathrm{~Hz})$, $123.7(d, J=3.0 \mathrm{~Hz}), 130.2(d, J=7.5 \mathrm{~Hz}), 139.6(d, J=7.5 \mathrm{~Hz}), 162.1(d, J$ = $242.2 \mathrm{~Hz}$ ), 164.8 (C-6), 167.1 (C-2), 168.5 (d, J = $3.1 \mathrm{~Hz}, \mathrm{C}-4)$. Anal. Calcd for $\mathrm{C}_{13} \mathrm{H}_{14} \mathrm{FN}_{5} \mathrm{O}$ : C, 56.72; H, 5.13; N, 25.44. Found C, 56.55; H, 5.20; N, 25.32 .

4-(4-Fluorophenyl)-6-morpholino-1,3,5-triazin-2-amine (1c).

White solid; yield $239 \mathrm{mg}$ (35\%); mp 186-187 ${ }^{\circ} \mathrm{C}$ (EtOH). ${ }^{1} \mathrm{H}$ NMR $(300$ MHz, DMSO- $\left.d_{6}\right): \delta 3.63-3.67\left(4 \mathrm{H}, m, \mathrm{CH}_{2} \mathrm{OCH}_{2}\right), 3.79\left(4 \mathrm{H}\right.$, br $s, \mathrm{CH}_{2} \mathrm{NCH}_{2}$ ), $6.96\left(2 \mathrm{H}, b r s, \mathrm{NH}_{2}\right), 7.29\left(2 \mathrm{H}, d d, J=8.8,8.8 \mathrm{~Hz}, \mathrm{H}-3^{\prime}\right.$ and $\left.\mathrm{H}-5^{\prime}\right), 8.35(2 \mathrm{H}$, $d d, J=5.9,8.7 \mathrm{~Hz}, \mathrm{H}-2^{\prime}$ and $\left.\mathrm{H}-6^{\prime}\right) .{ }^{13} \mathrm{C}$ NMR (75 MHz, DMSO- $\left.d_{6}\right): \delta 43.1$ $\left(\mathrm{CH}_{2} \mathrm{NCH}_{2}\right), 65.9\left(\mathrm{CH}_{2} \mathrm{OCH}_{2}\right), 115.0(2 \mathrm{C}, d, J=21.6 \mathrm{~Hz}), 130.1(2 \mathrm{C}, d, J=$ $8.9 \mathrm{~Hz}), 133.3(d, J=2.2 \mathrm{~Hz}), 164.1(d, J=248.3), 164.8(\mathrm{C}-6), 167.1(\mathrm{C}-2)$, 168.7 (C-4). Anal. Calcd for $\mathrm{C}_{13} \mathrm{H}_{14} \mathrm{FN}_{5} \mathrm{O}: \mathrm{C}, 56.72 ; \mathrm{H}, 5.13 ; \mathrm{N}, 25.44$. Found: C, 56.59 H, 5.20; N, 25.32.

4-(4-Chlorophenyl)-6-morpholino-1,3,5-triazin-2-amine (1d).

Yellowish solid; yield $264 \mathrm{mg}$ (36\%); mp 203-204 ${ }^{\circ} \mathrm{C}$ (EtOH), lit. ${ }^{38} 198$ $201{ }^{\circ} \mathrm{C}$. ${ }^{1} \mathrm{H}$ NMR (300 MHz, DMSO- $\left.d_{6}\right): \delta 3.63-3.67\left(4 \mathrm{H}, m, \mathrm{CH}_{2} \mathrm{OCH}_{2}\right.$ ), $3.79\left(4 \mathrm{H}, b r s, \mathrm{CH}_{2} \mathrm{NCH}_{2}\right), 6.99\left(2 \mathrm{H}\right.$, br $\left.s, \mathrm{NH}_{2}\right), 7.54\left(2 \mathrm{H}, d, J=8.7 \mathrm{~Hz}, \mathrm{H}-3^{\prime}\right.$ and $\left.\mathrm{H}-5^{\prime}\right), 8.30\left(2 \mathrm{H}, d, J=8.7 \mathrm{~Hz}, \mathrm{H}-2^{\prime}\right.$ and $\left.\mathrm{H}^{\prime} 6^{\prime}\right) .{ }^{13} \mathrm{C}$ NMR $(75 \mathrm{MHz}$, DMSO- $\left.d_{6}\right): \delta 43.1\left(\mathrm{CH}_{2} \mathrm{NCH}_{2}\right), 65.9\left(\mathrm{CH}_{2} \mathrm{OCH}_{2}\right), 128.2$ (2C), 129.5 (2C), 135.7, 136.0, 164.8 (C-6), 167.1 (C-2), 168.7 (C-4). Anal. Calcd for $\mathrm{C}_{13} \mathrm{H}_{14} \mathrm{ClN}_{5} \mathrm{O}$ : C, 53.52; H, 4.84; N, 24.01. Found: C, 53.39; H, 4.97; N, 23.94 .

4-(3-Methylphenyl)-6-morpholino-1,3,5-triazin-2-amine (1e).

White solid; yield $216 \mathrm{mg}$ (32\%); mp 151-152 ${ }^{\circ} \mathrm{C}$ (EtOH). ${ }^{1} \mathrm{H}$ NMR $(300$ MHz, DMSO-d $)$ ): $\delta 2.39$ (3H, s, Me), 3.64-3.69 (4H, $m, \mathrm{CH}_{2} \mathrm{OCH}_{2}$ ), $3.82(4 \mathrm{H}$, br $s, \mathrm{CH}_{2} \mathrm{NCH}_{2}$ ), $6.97\left(2 \mathrm{H}, b r s, \mathrm{NH}_{2}\right), 7.32-7.40\left(2 \mathrm{H}, m, \mathrm{H}-4^{\prime}\right.$ and $\left.\mathrm{H}^{\prime} 5^{\prime}\right)$, 8.10-8.17 $\left(2 \mathrm{H}, m, \mathrm{H}-2^{\prime}\right.$ and $\left.\mathrm{H}-6^{\prime}\right) .{ }^{13} \mathrm{C}$ NMR (75 MHz, DMSO- $\left.d_{6}\right): \delta 21.0$ (Me), $43.1\left(\mathrm{CH}_{2} \mathrm{NCH}_{2}\right), 66.0\left(\mathrm{CH}_{2} \mathrm{OCH}_{2}\right), 125.0,128.0,128.2,131.8,136.8$, 137.2, 164.9 (C-6), 167.1 (C-2), 169.7 (C-4). Anal. Calcd for $\mathrm{C}_{14} \mathrm{H}_{17} \mathrm{~N}_{5} \mathrm{O}$ : C, 61.98; H, 6.32; N, 25.81. Found: C, 61.85; H, 6.45; N, 25.69.

4-(4-Methylphenyl)-6-morpholino-1,3,5-triazin-2-amine (1f) 
White solid; yield $324 \mathrm{mg}$ (48\%); mp 167-168 ${ }^{\circ} \mathrm{C}(\mathrm{EtOH})$, lit.25 $167{ }^{\circ} \mathrm{C} .{ }^{1} \mathrm{H}$ NMR $\left(300 \mathrm{MHz}\right.$, DMSO- $\left.d_{6}\right): \delta 2.37(3 \mathrm{H}, s, \mathrm{Me}), 3.63-3.67(4 \mathrm{H}, m$ $\left.\mathrm{CH}_{2} \mathrm{OCH}_{2}\right), 3.79\left(4 \mathrm{H}, b r s, \mathrm{CH}_{2} \mathrm{NCH}_{2}\right), 6.92\left(2 \mathrm{H}, b r s, \mathrm{NH}_{2}\right), 7.27(2 \mathrm{H}, d, J=$ $8.0 \mathrm{~Hz}, \mathrm{H}-3^{\prime}$ and $\left.\mathrm{H}-5^{\prime}\right), 8.20\left(2 \mathrm{H}, d, J=8.2 \mathrm{~Hz}, \mathrm{H}-2^{\prime}\right.$ and $\left.\mathrm{H}-6^{\prime}\right) .{ }^{13} \mathrm{C} \mathrm{NMR}(75$ MHz, DMSO-d $\left.d_{6}\right): \delta 21.0(\mathrm{Me}), 43.1\left(\mathrm{CH}_{2} \mathrm{NCH}_{2}\right), 65.9\left(\mathrm{CH}_{2} \mathrm{OCH}_{2}\right), 127.8$ (2C), 128.7 (2C), 134.1, 141.0, 164.9 (C-6), 167.1 (C-2), 169.6 (C-4). Anal. Calcd for $\mathrm{C}_{14} \mathrm{H}_{17} \mathrm{~N}_{5} \mathrm{O}: \mathrm{C}, 61.98 ; \mathrm{H}, 6.32 ; \mathrm{N}, 25.81$. Found: C, 61.88; H, 6.41; N, 25.73 .

\section{4-(4-(tert-Butyl)phenyl)-6-morpholino-1,3,5-triazin-2-amine (1g).}

White solid; yield $418 \mathrm{mg}(53 \%) ; \mathrm{mp} 178-179{ }^{\circ} \mathrm{C}(\mathrm{EtOH}) .{ }^{1} \mathrm{H}$ NMR $(300$ MHz, DMSO- $\left.d_{6}\right): \delta 1.31\left(9 \mathrm{H}, s, \mathrm{C}(\mathrm{Me})_{3}\right), 3.63-3.67\left(4 \mathrm{H}, m, \mathrm{CH}_{2} \mathrm{OCH}_{2}\right), 3.78$ $\left(4 \mathrm{H}, b r s, \mathrm{CH}_{2} \mathrm{NCH}_{2}\right), 6.91\left(2 \mathrm{H}, b r s, \mathrm{NH}_{2}\right), 7.48\left(2 \mathrm{H}, d, J=8.6 \mathrm{~Hz}, \mathrm{H}-3^{\prime}\right.$ and $\left.\mathrm{H}-5^{\prime}\right), 8.21\left(2 \mathrm{H}, d, J=8.6 \mathrm{~Hz}, \mathrm{H}-2^{\prime}\right.$ and $\left.\mathrm{H}-6^{\prime}\right) .{ }^{13} \mathrm{C}$ NMR $\left(75 \mathrm{MHz}\right.$, DMSO- $\left.d_{6}\right)$ $\left.\delta 30.9\left(\mathrm{C}(\mathrm{Me})_{3}\right), 34.5\left(\mathrm{C}(\mathrm{Me})_{3}\right), 43.0\left(\mathrm{CH}_{2} \mathrm{NCH}_{2}\right), 65.9\left(\mathrm{CH}_{2} \mathrm{OCH}\right)_{2}\right), 124.8$ (2C), 127.6 (2C), 134.1, 153.9, 164.8 (C-6), 167.1 (C-2), 169.6 (C-4). Anal. Calcd for $\mathrm{C}_{17} \mathrm{H}_{23} \mathrm{~N}_{5} \mathrm{O}$ : C, 65.15; H, 7.40; N, 22.35. Found: C, 65.02; H, 7.53; N, 22.23.

\section{4-(4-(N,N-Dimethylamino)phenyl)-6-morpholino-1,3,5-triazin-2-amine}

\section{(1h).}

Yellow solid; yield $132 \mathrm{mg}$ (18\%); mp 209-210 ${ }^{\circ} \mathrm{C}(\mathrm{EtOH}) .{ }^{1} \mathrm{H}$ NMR (300 MHz, DMSO- $\left.d_{6}\right): \delta 2.99(\mathrm{Me}), 3.62-3.65\left(4 \mathrm{H}, m, \mathrm{CH}_{2} \mathrm{OCH}_{2}\right), 3.76(4 \mathrm{H}, b r s$, $\left.\mathrm{CH}_{2} \mathrm{NCH}_{2}\right), 6.71\left(2 \mathrm{H}, b r s, \mathrm{NH}_{2}\right), 6.72\left(2 \mathrm{H}, d, J=9.1 \mathrm{~Hz}, \mathrm{H}-3^{\prime}\right.$ and $\left.\mathrm{H}^{\prime} 5^{\prime}\right), 8.14$ $\left(2 \mathrm{H}, d, J=9.0 \mathrm{~Hz}, \mathrm{H}-2^{\prime}\right.$ and $\left.\mathrm{H}-6^{\prime}\right) .{ }^{13} \mathrm{C}$ NMR $\left(75 \mathrm{MHz}, \mathrm{DMSO}-d_{6}\right): \delta 39.6$ (N(Me) $)_{2}, 43.0\left(\mathrm{CH}_{2} \mathrm{NCH}_{2}\right), 65.9\left(\mathrm{CH}_{2} \mathrm{OCH}_{2}\right), 110.8(2 \mathrm{C}), 123.6,129.1$ (2C), 152.3, 164.8 (C-6), 166.9 (C-2), 169.6 (C-4). Anal. Calcd for $\mathrm{C}_{15} \mathrm{H}_{20} \mathrm{~N}_{6} \mathrm{O}$ : C, 59.98; H, 6.71; N, 27.98. Found: C, 59.87; H, 6.82; N, 27.85 .

\section{4-(4-Methoxyphenyl)-6-morpholino-1,3,5-triazin-2-amine (1i).}

Yellowish solid; yield $325 \mathrm{mg}(45 \%) ; \mathrm{mp} 182-183{ }^{\circ} \mathrm{C}(\mathrm{EtOH})$, lit. ${ }^{38} 177-$ $179^{\circ} \mathrm{C}$. ${ }^{1} \mathrm{H}$ NMR $\left(300 \mathrm{MHz}\right.$, DMSO-d $\left.d_{6}\right): \delta 3.64-3.68\left(4 \mathrm{H}, m, \mathrm{CH}_{2} \mathrm{OCH}_{2}\right)$, $3.80\left(4 \mathrm{H}, b r s, \mathrm{CH}_{2} \mathrm{NCH}_{2}\right), 3.83(3 \mathrm{H}, s, \mathrm{OMe}), 6.88\left(2 \mathrm{H}, b r s, \mathrm{NH}_{2}\right), 7.02(2 \mathrm{H}$, $d, J=9.0 \mathrm{~Hz}, \mathrm{H}-3^{\prime}$ and $\left.\mathrm{H}-5^{\prime}\right), 8.28\left(2 \mathrm{H}, d, J=9.0 \mathrm{~Hz}, \mathrm{H}-2^{\prime}\right.$ and $\left.\mathrm{H}-6^{\prime}\right) .{ }^{13} \mathrm{C}$ NMR $\left(75 \mathrm{MHz}\right.$, DMSO- $\left.d_{6}\right): \delta 43.1\left(\mathrm{CH}_{2} \mathrm{NCH}_{2}\right), 55.2$ (OMe), 66.0 $\left(\mathrm{CH}_{2} \mathrm{OCH}_{2}\right), 113.4$ (2C), 129.2, 129.5 (2C), 161.8, 164.9 (C-6), 167.1 (C-2), 169.3 (C-4). Anal. Calcd for $\mathrm{C}_{14} \mathrm{H}_{17} \mathrm{~N}_{5} \mathrm{O}_{2}$ : C, 58.52; H, 5.96; N, 24.38 Found: C, 58.39; H, 6.08; N, 24.23.

\section{4-(4-(Trifluoromethoxy)phenyl)-6-morpholino-1,3,5-triazin-2-amine (1j).}

White solid; yield $220 \mathrm{mg}$ (26\%); mp 141-142 ${ }^{\circ} \mathrm{C}(\mathrm{EtOH}) .{ }^{1} \mathrm{H}$ NMR (300 MHz, DMSO- $\left.d_{6}\right): \delta 3.64-3.67\left(4 \mathrm{H}, m, \mathrm{CH}_{2} \mathrm{OCH}_{2}\right), 3.79\left(4 \mathrm{H}, b r s, \mathrm{CH}_{2} \mathrm{NCH}_{2}\right.$ ), $7.04\left(2 \mathrm{H}, b r s, \mathrm{NH}_{2}\right), 7.46\left(2 \mathrm{H}, d, J=8.9 \mathrm{~Hz}, \mathrm{H}-3^{\prime}\right.$ and $\left.\mathrm{H}^{\prime} 5^{\prime}\right), 8.40(2 \mathrm{H}, d, J=$ $8.9 \mathrm{~Hz}, \mathrm{H}-2^{\prime}$ and $\left.\mathrm{H}-6^{\prime}\right) .{ }^{13} \mathrm{C}$ NMR (75 MHz, DMSO- $\left.d_{6}\right): \delta 43.1\left(\mathrm{CH}_{2} \mathrm{NCH}_{2}\right)$, $65.9\left(\mathrm{CH}_{2} \mathrm{OCH}_{2}\right), 119.9\left(q, J=257.4 \mathrm{~Hz}, \mathrm{OCF}_{3}\right), 120.4(2 \mathrm{C}), 129.8(2 \mathrm{C})$, 136.0, 150.4 ( $q, J=1.5 \mathrm{~Hz}$ ), 164.8 (C-6), 167.1 (C-2), 168.5 (C-4). Anal. Calcd for $\mathrm{C}_{14} \mathrm{H}_{14} \mathrm{~F}_{3} \mathrm{~N}_{5} \mathrm{O}_{2}$ : C, 49.27; $\mathrm{H}, 4.13 ; \mathrm{N}, 20.52$. Found: C, 49.13; H, 4.29; N, 20.40.

\section{6-Morpholino-4-(3-phenoxyphenyl)-1,3,5-triazin-2-amine (1 $\mathbf{k}$ )}

White solid; yield $480 \mathrm{mg}(55 \%) ; \mathrm{mp} 147-148{ }^{\circ} \mathrm{C}$ (EtOH). ${ }^{1} \mathrm{H}$ NMR $(300$ MHz, DMSO-d $d_{6}$ : $\delta 3.62-3.65\left(4 \mathrm{H}, m, \mathrm{CH}_{2} \mathrm{OCH}_{2}\right), 3.76\left(4 \mathrm{H}\right.$, br s, $\left.\mathrm{CH}_{2} \mathrm{NCH}_{2}\right)$, $6.95\left(2 \mathrm{H}, b r s, \mathrm{NH}_{2}\right), 7.04\left(2 \mathrm{H}, m, \mathrm{H}-6^{\prime \prime}\right.$ and $\left.\mathrm{H}-2^{\prime \prime}\right), 7.13-7.22\left(2 \mathrm{H}, m, \mathrm{H}-4^{\prime}\right.$ and $\left.\mathrm{H}-4^{\prime \prime}\right), 7.37-7.45\left(2 \mathrm{H}, m, \mathrm{H}-3^{\prime \prime}\right.$ and $\left.\mathrm{H}-5^{\prime \prime}\right), 7.49\left(1 \mathrm{H}, t, J=7.9 \mathrm{~Hz}, \mathrm{H}-5^{\prime}\right)$, $7.90\left(1 \mathrm{H}, d d, J=1.4,2.5 \mathrm{~Hz}, \mathrm{H}-2^{\prime}\right), 8.09\left(1 \mathrm{H}, d d d, J=1.2,1.4,7.8 \mathrm{~Hz}, \mathrm{H}-6^{\prime}\right)$ ${ }^{13} \mathrm{C}$ NMR (75 MHz, DMSO-d 6 ): $\delta 43.1\left(\mathrm{CH}_{2} \mathrm{NCH}_{2}\right), 65.9\left(\mathrm{CH}_{2} \mathrm{OCH}_{2}\right), 117.7$ (C-2'), 118.4 (2C), 121.6, 122.9, 123.4, 129.8, 130.0 (2C), 139.0, 156.5, 156.7, 164.8 (C-6), 167.1 (C-2), 169.0 (C-4). Anal. Calcd for $\mathrm{C}_{19} \mathrm{H}_{19} \mathrm{~N}_{5} \mathrm{O}_{2}: \mathrm{C}$ 65.32; H, 5.48; N, 20.04. Found: C, 65.19; H, 5.63; N, 19.88.

4-(3-(Benzyloxy)phenyl)-6-morpholino-1,3,5-triazin-2-amine (1I).

Light brown solid; yield $362 \mathrm{mg}(40 \%) ; \mathrm{mp} 161-162^{\circ} \mathrm{C}(\mathrm{MeCN}) .{ }^{1} \mathrm{H}$ NMR (300 MHz, DMSO- $\left.d_{6}\right): \delta 3.60-3.69\left(4 \mathrm{H}, m, \mathrm{CH}_{2} \mathrm{OCH}_{2}\right), 3.78(4 \mathrm{H}, b r s$, $\left.\mathrm{CH}_{2} \mathrm{NCH}_{2}\right), 5.17\left(2 \mathrm{H}, s, \mathrm{OCH} \mathrm{H}_{2} \mathrm{Ph}\right), 6.97\left(2 \mathrm{H}, b r s, \mathrm{NH}_{2}\right), 7.18(1 \mathrm{H}, d d d, J=$ 1.0, 2.6, 8.2 Hz, H-4'), 7.30-7.44 (4H, $m, \mathrm{H}-5^{\prime}, \mathrm{H}-3^{\prime \prime}, \mathrm{H}-4^{\prime \prime}$ and $\left.\mathrm{H}-5^{\prime \prime}\right), 7.46-$ $7.51\left(2 \mathrm{H}, m, \mathrm{H}-2^{\prime \prime}\right.$ and $\left.\mathrm{H}-6^{\prime \prime}\right), 7.88-7.96\left(2 \mathrm{H}, m, \mathrm{H}-2^{\prime}\right.$ and $\left.\mathrm{H}-6^{\prime}\right) .{ }^{13} \mathrm{C}$ NMR (75 MHz, DMSO-d $\left.d_{6}\right): \delta 43.1\left(\mathrm{CH}_{2} \mathrm{NCH}_{2}\right), 65.9\left(\mathrm{CH}_{2} \mathrm{OCH}_{2}\right), 69.2\left(\mathrm{OCH}_{2} \mathrm{Ph}\right)$, 113.9, 117.7, 120.3, 127.6 (2C), 127.8, 128.4 (2C), 129.2, 137.0, 138.4, 158.2, 164.8 (C-6), 167.1 (C-2), 169.4 (C-4). Anal. Calcd for $\mathrm{C}_{20} \mathrm{H}_{21} \mathrm{~N}_{5} \mathrm{O}_{2}$ : C, 66.10; H, 5.82; N, 19.27. Found: C, 65.89; H, 5.96; N, 19.11.

4-(4-(Benzyloxy)phenyl)-6-morpholino-1,3,5-triazin-2-amine (1m).
Yellow solid; yield $641 \mathrm{mg}$ (71\%); mp 164-165 ${ }^{\circ} \mathrm{C}(\mathrm{EtOH}) .{ }^{1} \mathrm{H}$ NMR (300 MHz, DMSO- $\left.d_{6}\right): \delta$ 3.61-3.66 (4H, $\left.m, \mathrm{CH}_{2} \mathrm{OCH}_{2}\right), 3.78\left(4 \mathrm{H}, b r s, \mathrm{CH}_{2} \mathrm{NCH}_{2}\right)$, $5.17\left(2 \mathrm{H}, s, \mathrm{OCH}_{2} \mathrm{Ph}\right), 6.86\left(2 \mathrm{H}, b r s, \mathrm{NH}_{2}\right), 7.09\left(2 \mathrm{H}, d, J=9.0 \mathrm{~Hz}, \mathrm{H}-3^{\prime}\right.$ and $\left.\mathrm{H}-5^{\prime}\right), 7.31-7.51\left(5 \mathrm{H}, m, \mathrm{OCH}_{2} P h\right), 8.25\left(2 \mathrm{H}, d, J=8.9 \mathrm{~Hz}, \mathrm{H}-2^{\prime}\right.$ and $\left.\mathrm{H}-6^{\prime}\right)$. ${ }^{13} \mathrm{C}$ NMR $\left(75 \mathrm{MHz}\right.$, DMSO-d 6 ): $\delta 43.1\left(\mathrm{CH}_{2} \mathrm{NCH}_{2}\right), 65.9\left(\mathrm{CH}_{2} \mathrm{OCH}_{2}\right), 69.3$ $\left(\mathrm{OCH}_{2} \mathrm{Ph}\right), 114.2(2 \mathrm{C}), 127.7(2 \mathrm{C}), 127.8,128.4(2 \mathrm{C}), 129.3,129.5(2 \mathrm{C})$, 136.7, 160.9, 164.8 (C-6), 167.0 (C-2), 169.2 (C-4). Anal. Calcd for $\mathrm{C}_{20} \mathrm{H}_{21} \mathrm{~N}_{5} \mathrm{O}_{2}: \mathrm{C}, 66.10 ; \mathrm{H}, 5.82 ; \mathrm{N}, 19.27$. Found: C, 65.98; H, 5.90; N, 19.13.

4-(3,4-Dimethoxyphenyl)-6-morpholino-1,3,5-triazin-2-amine (1n).

White solid; yield $297 \mathrm{mg}$ (37\%); mp $172-173{ }^{\circ} \mathrm{C}$ (EtOH). ${ }^{1} \mathrm{H}$ NMR (300 MHz, DMSO- $\left.d_{6}\right): \delta 3.63-3.67\left(4 \mathrm{H}, m, \mathrm{CH}_{2} \mathrm{OCH}_{2}\right), 3.78\left(4 \mathrm{H}\right.$, br $\left.s, \mathrm{CH}_{2} \mathrm{NCH}_{2}\right)$, $3.81(3 \mathrm{H}, s, \mathrm{OMe}), 3.82(3 \mathrm{H}, s, \mathrm{OMe}), 6.87\left(2 \mathrm{H}, b r s, \mathrm{NH}_{2}\right), 7.03(1 \mathrm{H}, d, J=$ $\left.8.6 \mathrm{~Hz}, \mathrm{H}-5^{\prime}\right), 7.85\left(1 \mathrm{H}, d, J=2.0 \mathrm{~Hz}, \mathrm{H}-2^{\prime}\right), 7.93(1 \mathrm{H}, d d, J=2.0,8.5 \mathrm{~Hz}, \mathrm{H}-$ $\left.6^{\prime}\right) .{ }^{13} \mathrm{C}$ NMR (75 MHz, DMSO-d6): $\delta 43.1\left(\mathrm{CH}_{2} \mathrm{NCH}_{2}\right), 55.3(\mathrm{OMe}), 55.4$ (OMe), $65.9\left(\mathrm{CH}_{2} \mathrm{OCH}_{2}\right), 110.7,110.9,121.3,129.2,148.1,151.5,164.8$ (C-6), 167.0 (C-2), 169.3 (C-4). Anal. Calcd for $\mathrm{C}_{15} \mathrm{H}_{19} \mathrm{~N}_{5} \mathrm{O}_{3}$ : C, 56.77; $\mathrm{H}$, 6.03; N, 22.07. Found: C, 56.69; H, 6.10; N, 21.98.

\section{4-(3,4,5-Trimethoxyphenyl)-6-morpholino-1,3,5-triazin-2-amine (1o).}

White solid; yield $358 \mathrm{mg}$ (41\%); mp 234-235 ${ }^{\circ} \mathrm{C}(\mathrm{EtOH})$, lit. ${ }^{39} 240{ }^{\circ} \mathrm{C} .{ }^{1} \mathrm{H}$ NMR (300 MHz, DMSO- $\left.d_{6}\right): \delta 3.64-3.67\left(4 \mathrm{H}, m, \mathrm{CH}_{2} \mathrm{OCH}_{2}\right), 3.73(3 \mathrm{H}, s$, OMe), $3.77\left(4 \mathrm{H}, b r s, \mathrm{CH}_{2} \mathrm{NCH}_{2}\right), 3.84(6 \mathrm{H}, s, 2 \times \mathrm{OMe}), 6.94\left(2 \mathrm{H}\right.$, br $\left.s, \mathrm{NH}_{2}\right)$, $7.62\left(2 \mathrm{H}, s, \mathrm{H}-2^{\prime}\right.$ and $\left.\mathrm{H}^{-6}{ }^{\prime}\right) .{ }^{13} \mathrm{C}$ NMR (75 MHz, DMSO- $\left.d_{6}\right): \delta 43.1$ $\left(\mathrm{CH}_{2} \mathrm{NCH}_{2}\right), 55.8(2 \times 0 \mathrm{OMe}), 60.0(\mathrm{OMe}), 65.9\left(\mathrm{CH}_{2} \mathrm{OCH}_{2}\right), 105.0(2 \mathrm{C})$, 132.2, 140.3, 152.5 (2C), 164.8 (C-6), 167.0 (C-2), 169.2 (C-4). Anal. Calcd for $\mathrm{C}_{16} \mathrm{H}_{21} \mathrm{~N}_{5} \mathrm{O}_{4}$ : C, 55.32; H, 6.09; N, 20.16. Found: C, 55.23; H, 6.22; N, 19.99.

6-Morpholino-4-(thiophen-2-yl)-1,3,5-triazin-2-amine (1p).

Light brown solid; yield $352 \mathrm{mg}(53 \%)$; mp $145-146{ }^{\circ} \mathrm{C}$ (EtOH). ${ }^{1} \mathrm{H}$ NMR (300 MHz, DMSO- $\left.d_{6}\right): \delta 3.62-3.66\left(4 \mathrm{H}, m, \mathrm{CH}_{2} \mathrm{OCH}_{2}\right), 3.75(4 \mathrm{H}, b r s$, $\left.\mathrm{CH}_{2} \mathrm{NCH}_{2}\right), 6.96\left(2 \mathrm{H}\right.$, br s, $\left.\mathrm{NH}_{2}\right), 7.16\left(1 \mathrm{H}, d d, J=3.7,5.0 \mathrm{~Hz}, \mathrm{H}-4^{\prime}\right), 7.73$ $\left(1 \mathrm{H}, d d, J=1.3,5.0 \mathrm{~Hz}, \mathrm{H}-5^{\prime}\right), 7.88\left(1 \mathrm{H}, d d, J=1.2,3.7 \mathrm{~Hz}, \mathrm{H}-3^{\prime}\right) .{ }^{13} \mathrm{C}$ NMR $\left(75 \mathrm{MHz}, \mathrm{DMSO}-d_{6}\right): \delta 43.0\left(\mathrm{CH}_{2} \mathrm{NCH}_{2}\right), 65.9\left(\mathrm{CH}_{2} \mathrm{OCH}_{2}\right), 127.9,129.1$, 130.6, 142.7, 164.4 (C-6), 166.1 (C-2), 166.8 (C-4). Anal. Calcd for $\mathrm{C}_{11} \mathrm{H}_{13} \mathrm{~N}_{5} \mathrm{OS}$ : C, 50.18; H, 4.98; N, 26.60. Found: C, 50.06; H, 5.07; N, 26.39. 6-Phenyl-4-pyrrolidino-1,3,5-triazin-2-amine (1q).

White solid; yield $87 \mathrm{mg}$ (14\%); mp 230-231 ${ }^{\circ} \mathrm{C}(\mathrm{EtOH})$, lit. $24230{ }^{\circ} \mathrm{C} .{ }^{1} \mathrm{H}$ NMR (300 MHz, DMSO-d $\left.d_{6}\right): \delta 1.88-1.94\left(4 \mathrm{H}, m, \mathrm{CH}_{2} \mathrm{CH}_{2}\right), 3.44-3.50(2 \mathrm{H}$, $\left.m, \mathrm{CH}_{2} \mathrm{NCH}_{2}\right), 3.58-3.64\left(2 \mathrm{H}, m, \mathrm{CH}_{2} \mathrm{NCH}_{2}\right), 6.82\left(2 \mathrm{H}, b r s, \mathrm{NH}_{2}\right), 7.42-7.54$ (3H, $m, \mathrm{H}-3^{\prime}, \mathrm{H}-4^{\prime}$, and $\left.\mathrm{H}-5^{\prime}\right), 8.27-8.32\left(2 \mathrm{H}, m, \mathrm{H}-2^{\prime}\right.$ and $\left.\mathrm{H}-6^{\prime}\right) .{ }^{13} \mathrm{C}$ NMR (75 MHz, DMSO- $\left.d_{6}\right): \delta 24.65\left(\mathrm{CH}_{2}\right), 24.73\left(\mathrm{CH}_{2}\right), 45.6\left(\mathrm{CH}_{2} \mathrm{~N}\right), 45.8$ $\left(\mathrm{CH}_{2} \mathrm{~N}\right), 127.6(2 \mathrm{C}), 128.0(2 \mathrm{C}), 130.9,137.1,163.5$ (C-6), 166.9 (C-2), 169.1 (C-4). Anal. Calcd for $\mathrm{C}_{13} \mathrm{H}_{15} \mathrm{~N}_{5}$ : C, 64.71; H, 6.27; N, 29.02. Found: C, $64.55 ; \mathrm{H}, 6.47 ; \mathrm{N}, 28.90$.

6-Phenyl-4-piperidino-1,3,5-triazin-2-amine (1r).

White solid; yield $61 \mathrm{mg}(10 \%) ; \mathrm{mp} 146-147^{\circ} \mathrm{C}(\mathrm{EtOH})$, lit. $^{40} 149-151^{\circ} \mathrm{C}$. ${ }^{1} \mathrm{H}$ NMR (300 MHz, DMSO- $\left.d_{6}\right): \delta 1.46-1.55\left(4 \mathrm{H}, m, \mathrm{CH}_{2} \mathrm{CH}_{2} \mathrm{CH}_{2}\right), 1.59-1.66$ ( $\left.4 \mathrm{H}, m, \mathrm{CH}_{2} \mathrm{CH}_{2} \mathrm{CH}_{2}\right), 3.80\left(4 \mathrm{H}\right.$, br s, $\left.\mathrm{CH}_{2} \mathrm{NCH}_{2}\right), 6.84\left(2 \mathrm{H}\right.$, br s, $\left.\mathrm{NH}_{2}\right), 7.42-$ $7.53\left(3 \mathrm{H}, m, \mathrm{H}-3^{\prime}, \mathrm{H}-4^{\prime}\right.$, and $\left.\mathrm{H}-5^{\prime}\right), 8.26-8.31\left(2 \mathrm{H}, m, \mathrm{H}-2^{\prime}\right.$ and $\left.\mathrm{H}-6^{\prime}\right) .{ }^{13} \mathrm{C}$ NMR (75 MHz, DMSO-d $\left.d_{6}\right): \delta 24.2\left(\mathrm{CH}_{2}\right), 25.3(2 \mathrm{x} \mathrm{CH}), 43.4\left(\mathrm{CH}_{2} \mathrm{NCH}_{2}\right)$, 127.6 (2C), 128.0 (2C), 131.0, 137.1, 164.5 (C-6), 167.2 (C-2), 169.5 (C4). Anal. Calcd for $\mathrm{C}_{14} \mathrm{H}_{17} \mathrm{~N}_{5}$ : C, 65.86; H, 6.71; N, 27.43. Found: $\mathrm{C}, 65.73$; H, 6.85; N, 27.28.

4-(4-Methylpiperidino)-6-phenyl-1,3,5-triazin-2-amine (1s).

White solid; yield $58 \mathrm{mg}(9 \%) ; \mathrm{mp}>300^{\circ} \mathrm{C}\left(\right.$ EtOH). ${ }^{1} \mathrm{H} \mathrm{NMR}(300 \mathrm{MHz}$, DMSO- $\left.d_{6}\right): \delta 0.93(3 \mathrm{H}, d, J=6.3 \mathrm{~Hz}, \mathrm{Me}), 1.00-1.11\left(2 \mathrm{H}, m, \mathrm{CH}_{2} \mathrm{CHMeCH}_{2^{-}}\right.$ ax), 1.61-1.71 (3H, $m, \mathrm{CHMe}, \mathrm{CH}_{2} \mathrm{NCH}_{2}$-ax), $2.86(2 \mathrm{H}, b r t, J=12.2 \mathrm{~Hz}$, $\mathrm{CH}_{2} \mathrm{CHMeCH}_{2}$-eq), 4.72 (1H, br $s, \mathrm{NCH}_{2}$-eq), 4.81 (1H, br $s, \mathrm{NCH}_{2}$-eq), 6.85 $\left(2 \mathrm{H}, b r s, \mathrm{NH}_{2}\right), 7.42-7.53\left(3 \mathrm{H}, m, \mathrm{H}-3^{\prime}, \mathrm{H}^{-} 4^{\prime}\right.$, and $\left.\mathrm{H}^{-} 5^{\prime}\right), 8.26-8.31(2 \mathrm{H}, m$, $\mathrm{H}-2^{\prime}$ and $\left.\mathrm{H}-6^{\prime}\right) .{ }^{13} \mathrm{C}$ NMR (75 MHz, DMSO- $\left.d_{6}\right): \delta 21.7(\mathrm{Me}), 30.6\left(2 \mathrm{x} \mathrm{CH}_{2}\right)$, 33.5 ( $\mathrm{CHMe}), 42.7\left(\mathrm{CH}_{2} \mathrm{NCH}_{2}\right), 127.6$ (2C), $128.0(2 \mathrm{C}), 131.0,137.1,164.5$ (C-6), 167.2 (C-2), 169.6 (C-4). Anal. Calcd for $\mathrm{C}_{15} \mathrm{H}_{19} \mathrm{~N}_{5}$ : C, 66.89; H, 7.11; N, 26.00. Found: C, 66.78; H, 7.23; N, 25.83.

4-(4-Methylpiperazino)-6-phenyl-1,3,5-triazin-2-amine (1t).

Yield $231 \mathrm{mg}$ (34\%); mp 173-174 ${ }^{\circ} \mathrm{C}$ (EtOH), lit. ${ }^{22}$ 171-174 ${ }^{\circ} \mathrm{C} .{ }^{1} \mathrm{H}$ NMR $\left(300 \mathrm{MHz}, \mathrm{DMSO}-d_{6}\right): \quad \delta 2.21(3 \mathrm{H}, s, \mathrm{NMe}), 2.32-2.38(4 \mathrm{H}, \mathrm{m}$, 
$\left.\mathrm{CH}_{2} \mathrm{~N}(\mathrm{Me}) \mathrm{CH}_{2}\right), 3.81\left(4 \mathrm{H}\right.$, br s, $\left.\mathrm{CH}_{2} \mathrm{NCH}_{2}\right), 6.92\left(2 \mathrm{H}\right.$, br $\left.s, \mathrm{NH}_{2}\right), 7.42-7.55$ (3H, $m, \mathrm{H}-3^{\prime}, \mathrm{H}-4^{\prime}$, and $\left.\mathrm{H}-5^{\prime}\right), 8.26-8.31\left(2 \mathrm{H}, m, \mathrm{H}-2^{\prime}\right.$ and $\left.\mathrm{H}-6^{\prime}\right) .{ }^{13} \mathrm{C}$ NMR (75 MHz, DMSO- $\left.d_{6}\right): \delta 42.4(\mathrm{NMe}), 45.7\left(\mathrm{CH}_{2} \mathrm{NCH}_{2}\right), 54.3\left(\mathrm{CH}_{2} \mathrm{~N}(\mathrm{Me}) \mathrm{CH}_{2}\right)$ 127.7 (2C), 128.1 (2C), 131.1, 136.9, 164.7 (C-6), 167.1 (C-2), 169.6 (C 4). Anal. Calcd for $\mathrm{C}_{14} \mathrm{H}_{18} \mathrm{~N}_{6}: \mathrm{C}, 62.20 ; \mathrm{H}, 6.71 ; \mathrm{N}, 31.09$. Found: $\mathrm{C}, 62.07$; H, 6.82; N, 30.92.

\section{4-(3,4-Dihydroisoquinolin-2(1H)-yl)-6-phenyl-1,3,5-triazin-2-amine (1u).}

Yellowish solid; yield $290 \mathrm{mg}$ (38\%); mp 139-140 ${ }^{\circ} \mathrm{C}$ (EtOH). ${ }^{1} \mathrm{H}$ NMR (300 MHz, DMSO-d $): \delta 2.88\left(2 \mathrm{H}, b r t, J=6.0 \mathrm{~Hz}, \mathrm{NCH}_{2} \mathrm{CH}_{2}\right), 4.01(1 \mathrm{H}$, br $\left.\mathrm{NCH}_{2} \mathrm{CH}_{2}\right), 4.11\left(1 \mathrm{H}, b r s, \mathrm{NCH}_{2} \mathrm{CH}_{2}\right), 4.89(1 \mathrm{H}, b r s, \mathrm{NCH} 2 \mathrm{Ar}), 5.02(1 \mathrm{H}, b r$ $\left.s, \mathrm{NCH}_{2} \mathrm{Ar}\right), 6.96\left(2 \mathrm{H}\right.$, br $\left.s, \mathrm{NH}_{2}\right), 7.18-7.32\left(4 \mathrm{H}, m, \mathrm{NCH}_{2} \mathrm{ArCH}_{2}\right), 7.45-7.58$ (3H, $m, \mathrm{H}-3^{\prime}, \mathrm{H}-4^{\prime}$, and $\left.\mathrm{H}-5^{\prime}\right), 8.32-8.37\left(2 \mathrm{H}, m, \mathrm{H}-2^{\prime}\right.$ and $\left.\mathrm{H}-6{ }^{\prime}\right) .{ }^{13} \mathrm{C}$ NMR (75 MHz, DMSO- $\left.d_{6}\right): \delta 28.4\left(\mathrm{NCH}_{2} \mathrm{CH}_{2}\right), 40.4\left(\mathrm{NCH}_{2} \mathrm{CH}_{2}\right), 44.9\left(\mathrm{NCH}_{2} \mathrm{Ar}\right)$, 126.0, 126.2, 126.3, 127.7 (2C), 128.1 (2C), 131.1, 133.7 (br s), 134.7, 136.9, 164.8 (C-6), 167.1 (C-2), 169.6 (C-4). Anal. Calcd for $\mathrm{C}_{18} \mathrm{H}_{17} \mathrm{~N}_{5}$ : C, 71.27; H, 5.65; N, 23.09. Found: C, 71.17; H, 5.76; N, 22.91.

\section{$\mathrm{X}$-ray crystal structure determination}

Intensity data for $\mathbf{1 1}$ and $\mathbf{1 n}$ were measured for colourless crystals (11: $0.07 \times 0.17 \times 0.19 \mathrm{~mm} ; 1 \mathrm{~m}: 0.10 \times 0.15 \times 0.18 \mathrm{~mm}$ ) at $100 \mathrm{~K}$ on an Rigaku/Oxford Diffraction XtaLAB Synergy diffractometer (Dualflex, AtlasS2) fitted with CuK $\alpha$ radiation $(\lambda=1.54178 \AA)$ so that $\theta(100 \%$ data completeness) $=67.1$ and $67.7^{\circ}$, respectively. Data reduction and Gaussian absorption corrections were by standard methods. ${ }^{41}$ The structures were solved by direct methods ${ }^{42}$ and refined (anisotropic displacement parameters and with $\mathrm{C}$-bound $\mathrm{H}$ atoms included in the riding model approximation) on $F^{2} .43$ The $\mathrm{N}$-bound $\mathrm{H}$ atoms were refined with $\mathrm{N}-\mathrm{H}=0.88 \pm 0.01 \AA$. A weighting scheme of the form $\mathrm{w}=$ $1 /\left[\sigma^{2}\left(F_{0}^{2}\right)+(a P)^{2}+b P\right]$, where $\left.P=\left(F_{0}^{2}+2 F_{c}^{2}\right) / 3\right)$, was introduced in each case. The molecular structure diagrams showing $70 \%$ probability displacement ellipsoids were generated by ORTEP for Windows ${ }^{44}$ and the packing diagrams with DIAMOND. ${ }^{45}$ Additional data analysis was made with PLATON. ${ }^{46}$

Crystal data for 1I. $\mathrm{C}_{20} \mathrm{H}_{21} \mathrm{~N}_{5} \mathrm{O}_{2}, M=363.42$, triclinic, $P^{-} 1, a=5.32441(9)$, $b=9.52388(12), c=17.7526(3) \AA, \alpha=90.2806(12), \beta=97.7765(14), \gamma=$ 91.0148(12) ${ }^{\circ}, V=891.77(2) \AA^{3}, Z=2, D_{\mathrm{x}}=1.353 \mathrm{~g} \mathrm{~cm}^{-3}, F(000)=384, \mu=$ $0.737 \mathrm{~mm}^{-1}$, no. reflns meas. $=21209$, no. unique reflns $=3185\left(R_{\text {int }}=\right.$ 0.020 ), no. reflns with $I \geq 2 \sigma(I)=3083$, no. parameters $=250, R$ (obs. data) $=0.033, a$ and $b$ in weighting scheme $=0.051$ and $0.256, w R 2$ (all data) $=0.090$. CCDC deposition number: 2035574 .

Crystal data for 1n. $\mathrm{C}_{15} \mathrm{H}_{19} \mathrm{~N}_{5} \mathrm{O}_{3}, M=317.35$, monoclinic, $P 2{ }_{1} / c, a=$ 8.2512(2), $b=14.9301(4), c=12.1258(3) \AA, \beta=99.743(3)^{\circ}, V=$ $1472.25(7) \AA^{3}, Z=4, D_{\mathrm{x}}=1.432 \mathrm{~g} \mathrm{~cm}^{-3}, F(000)=672, \mu=0.853 \mathrm{~mm}^{-1}$, no. reflns meas. $=19752$, no. unique reflns $=3045\left(R_{\text {int }}=0.042\right)$, no. reflns with $I \geq 2 \sigma(I)=2746$, no. parameters $=216, R$ (obs. data) $=0.042, a$ and $b$ in weighting scheme $=0.078$ and $0.443, w R 2$ (all data) $=0.126$. CCDC deposition number: 2035575.

\section{Antiproliferative activity screening}

The Jurkat-T cells (human leukemic T cell, clone E6-1) from American Type Culture Collection (ATCC) were cultured in RPM1-1640 medium (Nacalai Tesque, Japan) supplemented with $10 \% \mathrm{v} / \mathrm{v}$ foetal bovine serum (FBS) (Biosera, France) and maintained at $37{ }^{\circ} \mathrm{C}$ in a humidified $5 \% \mathrm{CO}_{2}$ incubator (Thermo Fisher, USA). The MTS assay ${ }^{47}$ was used in the cell viability experiments. A total of $2 \times 10^{4}$ cells in $50 \mu \mathrm{L}$ cell culture media were seeded into each well of a 96-well plate and incubated for $24 \mathrm{~h}$. Then, tested compounds or reference drugs [6-mercaptopurine (Merck Millipore, Germany), methotrexate (Merck Millipore, Germany), and cytarabine (Merck Millipore, Germany)] were added followed by the incubation for $72 \mathrm{~h}$. After that, a mixture of 3-(4,5-dimethylthiazol-2-yl)5-(3-carboxymethoxyphenyl)-2-(4-sulfophenyl)-2 $H$-tetrazolium inner salt (MTS) (Sigma Aldrich, USA) and phenazine methosulfate (Nacalai Tesque, Japan) was added to each well, followed by another incubation for $1-4 \mathrm{~h}$ at $37 \stackrel{\circ}{\circ}$. The absorbance in each well was measured at $490 \mathrm{~nm}$ using a microplate reader (Tecan NanoQuant Infinite M200 Pro, Austria). The percentage of cell viability was estimated by comparing absorbance in wells with the treated and untreated (vehicle control) cells using the following formula: $O D_{\text {treated }} / O D_{\text {untreated }} \times 100 \%$. All experiments were done in triplicates and repeated in three independent experiments. The
GI50 values were calculated using sigmoidal concentration-response curves generated by the GraphPad Prism 8 program. ${ }^{48}$

\section{Funding Information}

This work is supported by the Ministry of Higher Education, Malaysia under Fundamental Research Grant Scheme (Grant no. FRGS/1/2020/STG04/MUSM/02/2). This work also received partial support from the School of Pharmacy, Monash University Malaysia (Bridging Grant 2020). Sunway University Sdn Bhd is thanked for the financial support of the X-ray crystallography laboratory (Grant no. STRRCTR-RCCM-001-2019).

\section{Supporting Information}

YES (this text will be updated with links prior to publication)

\section{Primary Data}

NO (this text will be deleted prior to publication)

\section{References}

(1) Müller, G., History of the Discovery and Development of Triazine Herbicides. In The Triazine Herbicides; LeBaron, H. M.; McFarland, J. E.; Burnside, O. C., Eds.; Elsevier: San Diego, 2008; pp 13-29.

(2) Stock, M. L.; Elazab, S. T.; Hsu, W. H., Review of triazine antiprotozoal drugs used in veterinary medicine. J. Vet. Pharmacol. Therap. 2018, 41, 184-194.

(3) Shah, D. R.; Modh, R. P.; Chikhalia, K. H., Privileged s-triazines: structure and pharmacological applications. Future Med. Chem. 2014, 6, 463-477.

(4) Lim, F. P. L.; Dolzhenko, A. V., 1,3,5-Triazine-based analogues of purine: From isosteres to privileged scaffolds in medicinal chemistry. Eur. J. Med. Chem. 2014, 85, 371-390.

(5) Singla, P.; Luxami, V.; Paul, K., Triazine as a promising scaffold for its versatile biological behavior. Eur. J. Med. Chem. 2015, 102, 3957.

(6) Kumar, R.; Kumar, N.; Roy, R. K.; Singh, A. 1,3,5-Triazine analogs: A potent anticancer scaffold. Curr. Signal Transduct. Ther. 2019, 14, 87-106.

(7) Cascioferro, S.; Parrino, B.; Spanò, V.; Carbone, A.; Montalbano, A.; Barraja, P.; Diana, P.; Cirrincione, G., 1,3,5-Triazines: A promising scaffold for anticancer drugs development. Eur. J. Med. Chem. 2017, 142, 523-549.

(8) Kim, E. S., Enasidenib: First Global Approval. Drugs 2017, 77, 17051711.

(9) Stein, E. M., Enasidenib, a targeted inhibitor of mutant IDH2 proteins for treatment of relapsed or refractory acute myeloid leukemia. Future Oncol. 2017, 14, 23-40.

(10) del Campo, J. M.; Birrer, M.; Davis, C.; Fujiwara, K.; Gollerkeri, A.; Gore, M.; Houk, B.; Lau, S.; Poveda, A.; González-Martín, A.; Muller, C.; Muro, K.; Pierce, K.; Suzuki, M.; Vermette, J.; Oza, A., A randomized phase II non-comparative study of PF-04691502 and gedatolisib (PF-05212384) in patients with recurrent endometrial cancer. Gynecol. Oncol. 2016, 142 (1), 62-69.

(11) Britten, C. D.; Adjei, A. A.; Millham, R.; Houk, B. E.; Borzillo, G.; Pierce, K.; Wainberg, Z. A.; LoRusso, P. M., Phase I study of PF04691502, a small-molecule, oral, dual inhibitor of PI3K and mTOR, in patients with advanced cancer. Invest. New Drugs 2014, 32, 510517.

(12) Kawahata, W.; Asami, T.; Kiyoi, T.; Irie, T.; Taniguchi, H.; Asamitsu, Y.; Inoue, T.; Miyake, T.; Sawa, M. Design and synthesis of novel amino-triazine analogues as selective Bruton's tyrosine kinase inhibitors for treatment of rheumatoid arthritis. J. Med. Chem. 2018, 61, 8917-8933.

(13) La Rosee, P.; Jia, T.; Demehri, S.; Haertel, N.; de Vries, P.; Bonham, L.; Hollenback, D.; Singer, J. W.; Melo, J. V.; Druker, B. J.; Deininger, M. W. Antileukemic activity of lysophosphatidic acid acyltransferase- $\beta$ inhibitor CT32228 in chronic myelogenous 
leukemia sensitive and resistant to imatinib. Clin. Cancer Res. 2006 12, 6540-6546.

(14) Douvas, M. G.; Hogan, K. N.; Ji, Y.; Hollenback, D.; Bonham, L.; Singer, J. W.; Mitchell, B. S. Effect of lysophosphatidic acid acyltransferase- $\beta$ inhibition in acute leukemia. Leuk. Res. 2006, 30, 1027-1036.

(15) Poirier, M.; Awale, M.; Roelli, M. A.; Giuffredi, G. T.; Ruddigkeit, L.; Evensen, L.; Stooss, A.; Calarco, S.; Lorens, J. B.; Charles, R.-P.; Reymond, J.-L., Identifying lysophosphatidic acid acyltransferase $\beta$ (LPAAT- $\beta$ ) as the target of a nanomolar angiogenesis inhibitor from a phenotypic screen using the polypharmacology browser PPB2. ChemMedChem 2019, 14, 224-236.

(16) Junaid, A.; Lim, F. P. L.; Tiekink, E. R. T.; Dolzhenko, A. V., Design, synthesis, and biological evaluation of new 6, $N^{2}$-diaryl-1,3,5triazine-2,4-diamines as anticancer agents selectively targeting triple negative breast cancer cells. RSC Adv. 2020, 10, 2551725528.

(17) Jin, H.; Cianchetta, G.; Devasagayaraj, A.; Gu, K.; Marinelli, B.; Samala, L.; Scott, S.; Stouch, T.; Tunoori, A.; Wang, Y.; Zang, Y.; Zhang, C.; Kimball, S. D.; Main, A. J.; Ding, Z.-M.; Sun, W.; Yang, Q.; Yu, X.-Q.; Powell, D. R.; Wilson, A.; Liu, Q.; Shi, Z.-C., Substituted 3-(4(1,3,5-triazin-2-yl)-phenyl)-2-aminopropanoic acids as novel tryptophan hydroxylase inhibitors. Bioorg. Med. Chem. Lett. 2009, $19,5229-5232$

(18) Huang, X.-P.; Karpiak, J.; Kroeze, W. K.; Zhu, H.; Chen, X.; Moy, S. S.; Saddoris, K. A.; Nikolova, V. D.; Farrell, M. S.; Wang, S.; Mangano, T. J.; Deshpande, D. A.; Jiang, A.; Penn, R. B.; Jin, J.; Koller, B. H.; Kenakin, T.; Shoichet, B. K.; Roth, B. L. Allosteric ligands for the pharmacologically dark receptors GPR68 and GPR65. Nature 2015 527, 477-483.

(19) Yu, X.; Huang, X.-P.; Kenakin, T. P.; Slocum, S. T.; Chen, X.; Martini, M. L.; Liu, J.; Jin, J., Design, synthesis, and characterization of ogerinbased positive allosteric modulators for $\mathrm{G}$ protein-coupled receptor 68 (GPR68). J. Med. Chem. 2019, 62, 7557-7574.

(20) Dugar, S.; Hollinger, F. P.; Mahajan, D.; Sen, S.; Kuila, B.; Arora, R.; Pawar, Y.; Shinde, V.; Rahinj, M.; Kapoor, K. K.; Bhumkar, R.; Rai, S.; Kulkarni, R., Discovery of novel and orally bioavailable inhibitors of PI3 kinase based on indazole substituted morpholino-triazines. ACS Med. Chem. Lett. 2015, 6, 1190-1194.

(21) Mogilski, S.; Kubacka, M.; Łażewska, D.; Więcek, M.; Głuch-Lutwin, M.; Tyszka-Czochara, M.; Bukowska-Strakova, K.; Filipek, B.; KiećKononowicz, K., Aryl-1,3,5-triazine ligands of histamine $\mathrm{H}_{4}$ receptor attenuate inflammatory and nociceptive response to carrageen, zymosan and lipopolysaccharide. Inflamm. Res. 2017, 66, 79-95.

(22) Łażewska, D.; Więcek, M.; Ner, J.; Kamińska, K.; Kottke, T.; Schwed, J. S.; Zygmunt, M.; Karcz, T.; Olejarz, A.; Kuder, K.; Latacz, G.; Grosicki, M.; Sapa, J.; Karolak-Wojciechowska, J.; Stark, H.; KiećKononowicz, K., Aryl-1,3,5-triazine derivatives as histamine $\mathrm{H}_{4}$ receptor ligands. Eur. J. Med. Chem. 2014, 83, 534-546.

(23) Łażewska, D.; Kurczab, R.; Więcek, M.; Satała, G.; Kieć-Kononowicz, K.; Handzlik, J., Synthesis and computer-aided analysis of the role of linker for novel ligands of the $5-\mathrm{HT}_{6}$ serotonin receptor among substituted 1,3,5-triazinylpiperazines. Bioorg. Chem. 2019, 84, 319325 .

(24) Schramm, H. W.; Schubert-Zsilavecz, M.; Saracoglu, A. I.; Kratky, C., Über Reaktionen von Alkylbiguaniden mit Benzoin beim $\mathrm{pH}$ der Biguanidbasen. Monatsh. Chem. 1991, 122, 1063-1073.

(25) Dao, P.; Garbay, C.; Chen, H., Regioselective synthesis of imidazo[1,2- $a][1,3,5]$ triazines and 3,4-dihydroimidazo[1,2a][1,3,5]triazines from [1,3,5]triazin-2,4-diamines. Tetrahedron 2013, 69, 3867-3871.

(26) Xu, Y.; Shen, B.; Liu, L.; Qiao, C., Metal free [4+1] and [5+1] annulation reactions to prepare heterocycles using DMF and its derivatives as one-carbon source. Tetrahedron Lett. 2020, 61, 151844 .
(27) Zeng, M.; Wang, T.; Cui, D.-M.; Zhang, C., Ruthenium-catalyzed synthesis of tri-substituted 1,3,5-triazines from alcohols and biguanides. New J. Chem. 2016, 40, 8225-8228.

(28) Chaurasia, S. R.; Dange, R.; Bhanage, B. M., Graphene oxide as a carbo-catalyst for the synthesis of tri-substituted 1,3,5-triazines using biguanides and alcohols. Catal. Commun. 2020, 137, 105933.

(29) Junaid, A.; Lim, F. P. L.; Tiekink, E. R. T.; Dolzhenko, A. V., New onepot synthesis of 1,3,5-triazines: three-component condensation, Dimroth rearrangement, and dehydrogenative aromatization. ACS Comb. Sci. 2019, 21, 548-555.

(30) Junaid, A.; Lim, F. P. L.; Chuah, L. H.; Dolzhenko, A. V., 6, $N^{2}$-Diaryl1,3,5-triazine-2,4-diamines: synthesis, antiproliferative activity and 3D-QSAR modeling. RSC Adv. 2020, 10, 12135-12144.

(31) Modest, E. J., Chemical and Biological Studies on 1,2-Dihydro-striazines. II. Three-Component Synthesis. The Journal of Organic Chemistry 1956, 21, 1-13.

(32) Dolzhenko, A. V., Microwave-assisted multicomponent reactions. In Green Sustainable Process for Chemical and Environmental Engineering and Science: Microwaves in Organic Synthesis; Inamuddin; Boddula, R.; Asiri, A. M., Eds.; Elsevier: 2021; pp 205229.

(33) Junaid, A.; Dolzhenko, A. V., Microwave-assisted synthesis of 1,3,5triazines: efficient approaches to therapeutically valuable scaffold. Heterocycles 2019, 98, 1678-1706.

(34) Junaid, A.; Tan, Y. S.; Tiekink, E. R. T.; Dolzhenko, A. V., A one-pot synthesis of $N^{2}$,6-diaryl-5,6-dihydro-1,3,5-triazine-2,4-diamines and systematic evaluation of their ability to host ethanol in crystals. RSC Advances 2019, 9, 37660-37667.

(35) Anet, F. A. L.; Yavari, I., Nitrogen inversion in piperidine. J. Am. Chem. Soc. 1977, 99, 2794-2796.

(36) Rubiralta, M.; Giralt, E.; Diez, A., ${ }^{1} \mathrm{H}$ NMR Properties of Piperidine Derivatives. In Studies in Organic Chemistry. Piperidine: Structure, Preparation, Reactivity, and Synthetic Applications of Piperidine and its Derivatives, Elsevier: 1991; Vol. 43, pp 34-87.

(37) Kuwano, V. E.; Tniguchi, E.; Maekawa, K., Synthese von, 1,3,5Triazinen aus Aminosaüre-Derivaten (I). Agric. Biol. Chem. 1971, 35, 1572-1577.

(38) Colautti, A.; Maurich, V., s-Triazine sostituite e amidinouree a potenziale attività farmacologica. Farmaco Ed. Sci. 1973, 28, 531538.

(39) Guioca, V., Nouvelles triazines substituées et leur activité diurétique. Ann. Pharm. Fr. 1973, 31, 283-292.

(40) Shapiro, S. L.; Parrino, V. A.; Freedman, L., Guanamines. VIII. 6(Substituted phenyl)guanamines. J. Org. Chem. 1961, 26, 33313334.

(41) Rigaku Oxford Diffraction, CrysAlis PRO, Yarnton, Oxfordshire, England, 2017.

(42) Sheldrick, G. M., A short history of SHELX. Acta Crystallogr., Sect. A Found. Crystallogr. 2008, 64, 112-122.

(43) Sheldrick, G. M., Crystal structure refinement with SHELXL. Acta Crystallogr., Sect. C Struct. Chem. 2015, 71, 3-8.

(44) Farrugia, L. J., WinGX and ORTEP for Windows: an update. J. Appl. Crystallogr. 2012, 45, 849-854.

(45) Brandenburg, K., Diamond, Crystal Impact GbR, Bonn, Germany, 2006.

(46) Spek, A. L. Structure validation in chemical crystallography. Acta Crystallogr. Sect. D Biol. Crystallogr. 2009, 65, 148-155.

(47) Cory, A. H.; Owen, T. C.; Barltrop, J. A.; Cory, J. G., Use of an aqueous soluble tetrazolium/formazan assay for cell growth assays in culture. Cancer Commun. 1991, 3, 207-212.

(48) GraphPad Prism version 8.0.0 for Windows, GraphPad Software, San Diego, California USA. 


\section{Synthesis}

\section{Supporting Information}

\section{A new one-pot three-component synthesis of 4-aryl-6-cycloamino-1,3,5-triazin-2-amines under microwave irradiation}

\section{Muhammad Syafiq Bin Shahari ${ }^{\mathrm{a}}$, Ahmad Junaid ${ }^{\mathrm{b}}$, Edward R. T. Tiekink ${ }^{\mathrm{c}}$, and}

a School of Pharmacy, Monash University Malaysia, Jalan Lagoon Selatan, Bandar Sunway, Selangor Darul Ehsan 47500, Malaysia

${ }^{\mathrm{b}}$ Department of Medicinal Chemistry and Molecular Pharmacology, Purdue University, West Lafayette, Indiana 47907, USA

${ }^{\mathrm{c}}$ Research Centre for Crystalline Materials, School of Science and Technology, 5 Jalan Universiti, Sunway University, Bandar Sunway, Selangor Darul Ehsan 47500, Malaysia

${ }^{\mathrm{d}}$ School of Pharmacy and Biomedical Sciences, Curtin Health Innovation Research Institute, Faculty of Health Sciences, Curtin University, GPO Box U1987 Perth, Western Australia 6845, Australia

* Corresponding author. Email address: anton.dolzhenko@monash.edu (A. V. Dolzhenko) 


\section{Contents}

Table S1. Optimization of reaction conditions for the synthesis of 4-(4-methylphenyl)-6-morpholino-1,3,5-triazin-2-amine (1f) under microwave irradiation

Figure S1. Molecular packing in $\mathbf{1 1}$.

Figure S2. Molecular packing in $\mathbf{1 n}$.

Copies of ${ }^{1} \mathrm{H}$ and ${ }^{13} \mathrm{C}$ NMR spectra for prepared 4-aryl-6-cycloamino1,3,5-triazin-2-amines (1a-u)

Figure S3. Concentration-dependent antiproliferative effect of $\mathbf{1 u}$ against Jurkat-T cells.

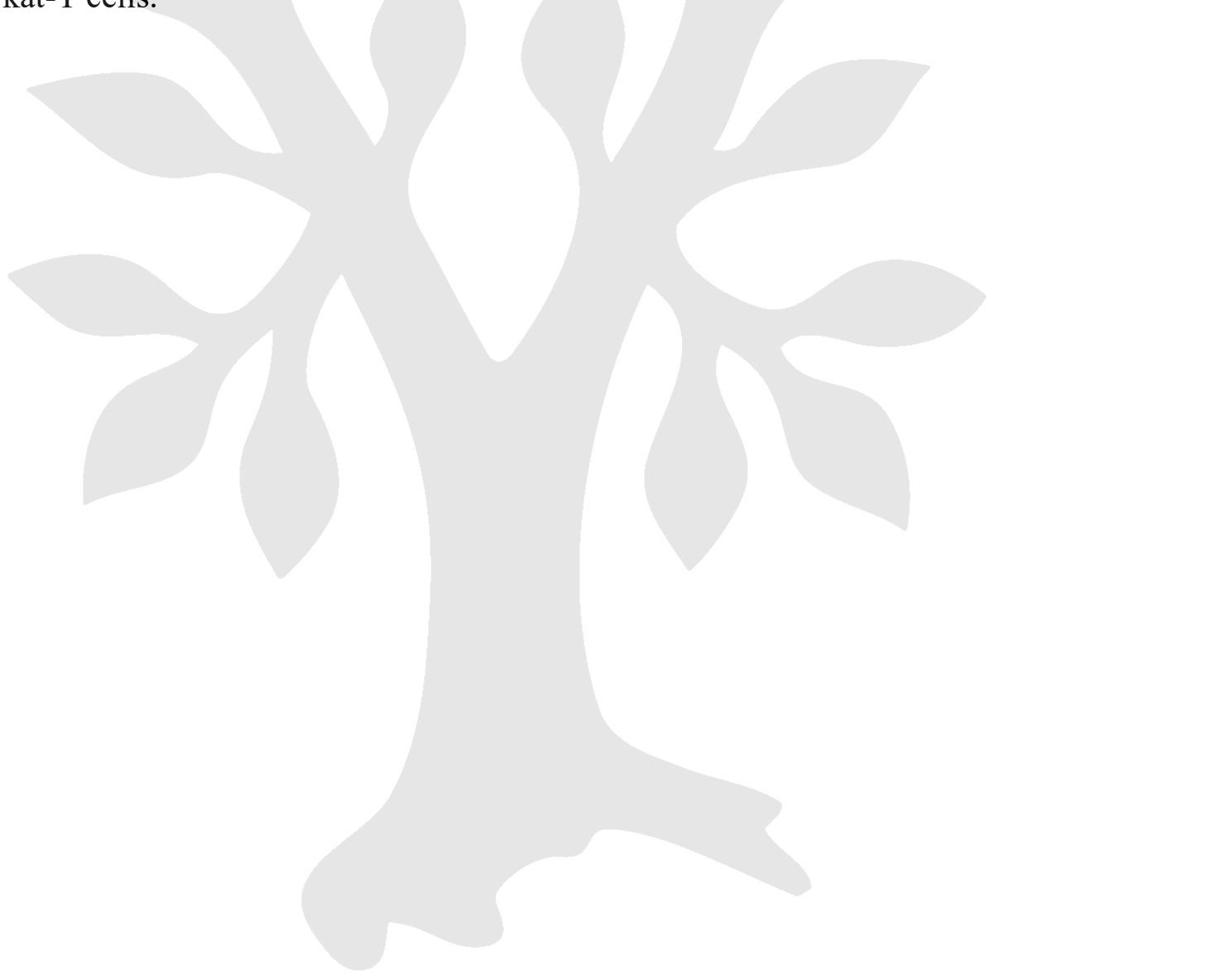


Table S1. Optimization of reaction conditions for the synthesis of 4-(4-methylphenyl)-6morpholino-1,3,5-triazin-2-amine (1f) under microwave irradiation. ${ }^{\text {a }}$<smiles>Cc1ccc(C=O)cc1</smiles>

(i) solvent, $\mathrm{HCl}$ (conc.), $\mathrm{MW}$;<smiles>Cc1ccc(-c2nc(N)nc(N3CCOCC3)n2)cc1</smiles><smiles>N#CNC(=N)N</smiles>

\begin{tabular}{|c|c|c|c|c|c|}
\hline \multirow[t]{2}{*}{ Entry } & \multirow[t]{2}{*}{ Solvent } & \multirow[t]{2}{*}{ Temperature, ${ }^{\circ} \mathrm{C}$} & \multicolumn{2}{|c|}{ Reaction time, min } & \multirow[t]{2}{*}{ Yield, ${ }^{\mathrm{b}} \%$} \\
\hline & & & (i) & (ii) & \\
\hline 1 & $\mathrm{MeOH}$ & 140 & 20 & 15 & 33 \\
\hline 2 & $\mathrm{EtOH}$ & 140 & 20 & 15 & 37 \\
\hline 3 & $\mathrm{PrOH}$ & 140 & 20 & 15 & 9 \\
\hline 4 & $\mathrm{EtOH}$ & 130 & 20 & 15 & 28 \\
\hline 5 & $\mathrm{EtOH}$ & 150 & 20 & 15 & 31 \\
\hline 6 & $\mathrm{EtOH}$ & 140 & 15 & 15 & 20 \\
\hline 7 & $\mathrm{EtOH}$ & 140 & 30 & 15 & 38 \\
\hline 8 & $\mathrm{EtOH}$ & 140 & 40 & 15 & 40 \\
\hline 9 & $\mathrm{EtOH}$ & 140 & 50 & 15 & 39 \\
\hline 10 & $\mathrm{EtOH}$ & 140 & 55 & 15 & 44 \\
\hline 11 & $\mathrm{EtOH}$ & 140 & 60 & 15 & 39 \\
\hline 12 & $\mathrm{EtOH}$ & 140 & 55 & 5 & 39 \\
\hline 13 & $\mathrm{EtOH}$ & 140 & 55 & 10 & 43 \\
\hline 14 & $\mathrm{EtOH}$ & 140 & 55 & 20 & 48 \\
\hline 15 & $\mathrm{EtOH}$ & 140 & 55 & 25 & 46 \\
\hline 16 & $\mathrm{EtOH}$ & 140 & 55 & 60 & 41 \\
\hline $17^{\mathrm{c}}$ & $\mathrm{EtOH}$ & 140 & 55 & 20 & 33 \\
\hline $18^{\mathrm{d}}$ & $\mathrm{EtOH}$ & 140 & 55 & 20 & 26 \\
\hline $19^{\mathrm{e}}$ & $\mathrm{EtOH}$ & 140 & 55 & 20 & 6 \\
\hline $20^{f}$ & $\mathrm{EtOH}$ & 140 & 55 & 20 & 33 \\
\hline
\end{tabular}

${ }^{a}$ The reactions were performed in a Monowave 400 microwave reactor (Anton Paar, Austria) using cyanoguanidine $(2.5 \mathrm{mmol})$, $p$-tolualdehyde $(2.5 \mathrm{mmol})$, morpholine $(2.5 \mathrm{mmol})$, and conc. $\mathrm{HCl}(2.5 \mathrm{mmol})$ in $2 \mathrm{~mL}$ of the specified solvent in step (i) and addition of $1 \mathrm{~mL}$ of $5 \mathrm{~N} \mathrm{NaOH}$ (aq.) in step (ii).

${ }^{\mathrm{b}}$ Isolated yield calculated on the basis of cyanoguanidine.

${ }^{c}$ The reaction was carried out using $5 \mathrm{mmol}$ of $p$-tolualdehyde.

${ }^{\mathrm{d}}$ Another $2.5 \mathrm{mmol}$ of $p$-tolualdehyde was added to the reaction mixture in step (ii). e $0.5 \mathrm{~mL}$ of $5 \mathrm{~N} \mathrm{NaOH}$ (aq.) [2.5 mmol] was used in step (ii).

$\mathrm{f}$ The reaction was performed in a Monowave 50 reactor (Anton Paar, Austria) without microwave irradiation. 


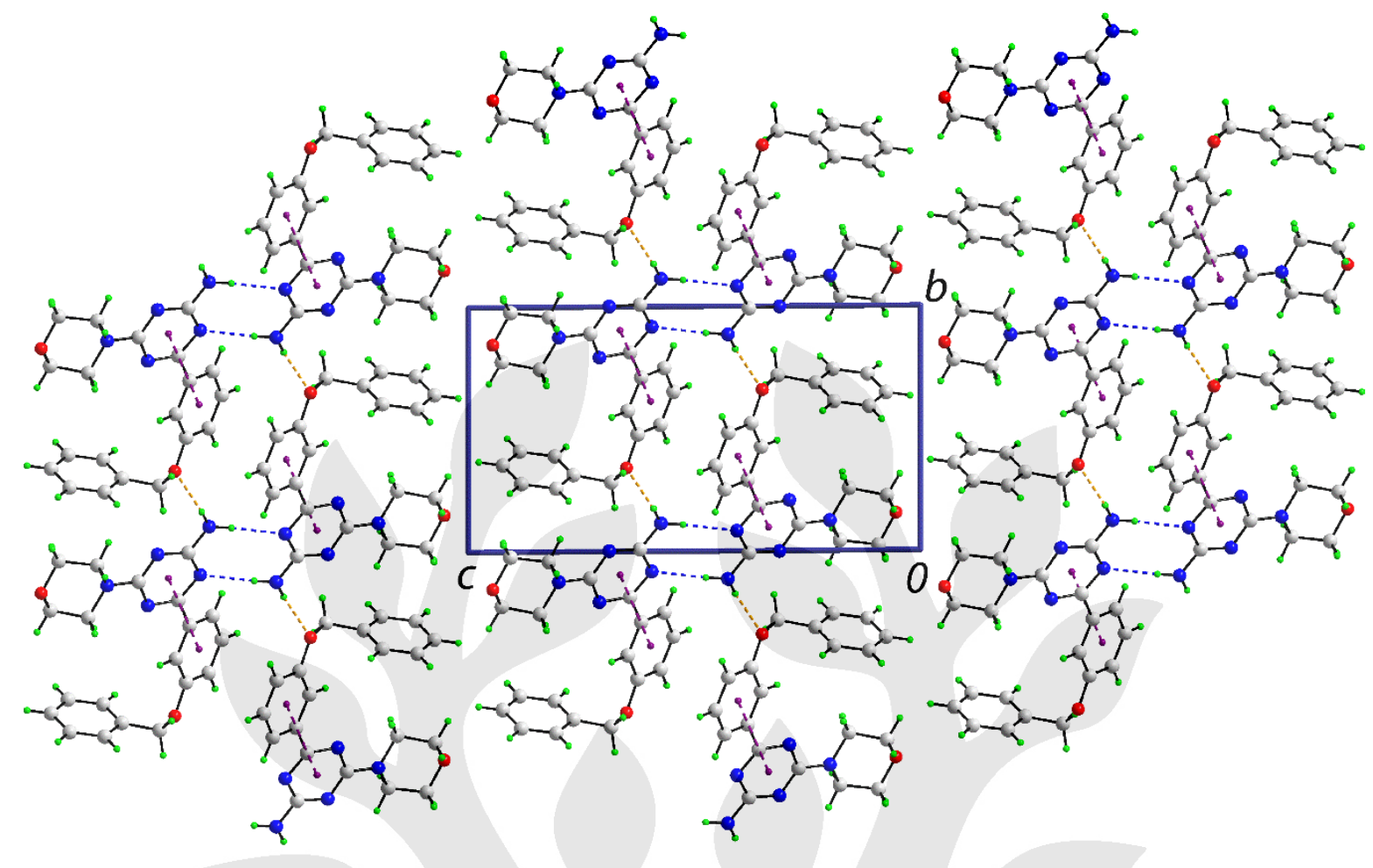

Figure S1. Molecular packing in 11: a view in projection down the a-axis of the unit cell contents. The $\mathrm{N}-\mathrm{H} \cdots \mathrm{O}, \mathrm{N}-\mathrm{H} \cdots \mathrm{N}$, and $\pi \cdots \pi$ interactions are shown as orange, blue, and purple dashed lines, respectively.

Geometric parameters $\left(\AA,{ }^{\circ}\right)$ characterising the identified intermolecular interactions:

$\begin{array}{llllllll}\text { A } & \mathrm{H} & \mathrm{B} & \mathrm{A}-\mathrm{H} & \mathrm{H} \cdots \mathrm{B} & \mathrm{A} \cdots \mathrm{B} & \mathrm{A}-\mathrm{H} \cdots \mathrm{B} & \begin{array}{l}\text { symmetry } \\ \text { operation }\end{array} \\ \mathrm{N} 2 & \mathrm{H} 1 \mathrm{n} & \mathrm{N} 3 & 0.893(9) & 2.129(9) & 3.0160(12) & 172.2(10) & 1-x, 2-y, 1-z \\ \mathrm{~N} 2 & \mathrm{H} 2 \mathrm{n} & \mathrm{O} 1 & 0.879(11) & 2.138(12) & 2.9903(11) & 163.4(10) & 1+x, 1+y, z\end{array}$

$\mathrm{Cg}(\mathrm{N} 1-\mathrm{N} 3, \mathrm{C} 2, \mathrm{C} 4, \mathrm{C} 6)$

$\mathrm{Cg}(\mathrm{C} 41-\mathrm{C} 46)$

3.8674(6) $26.77(5) \quad 1+x, y, z$ 


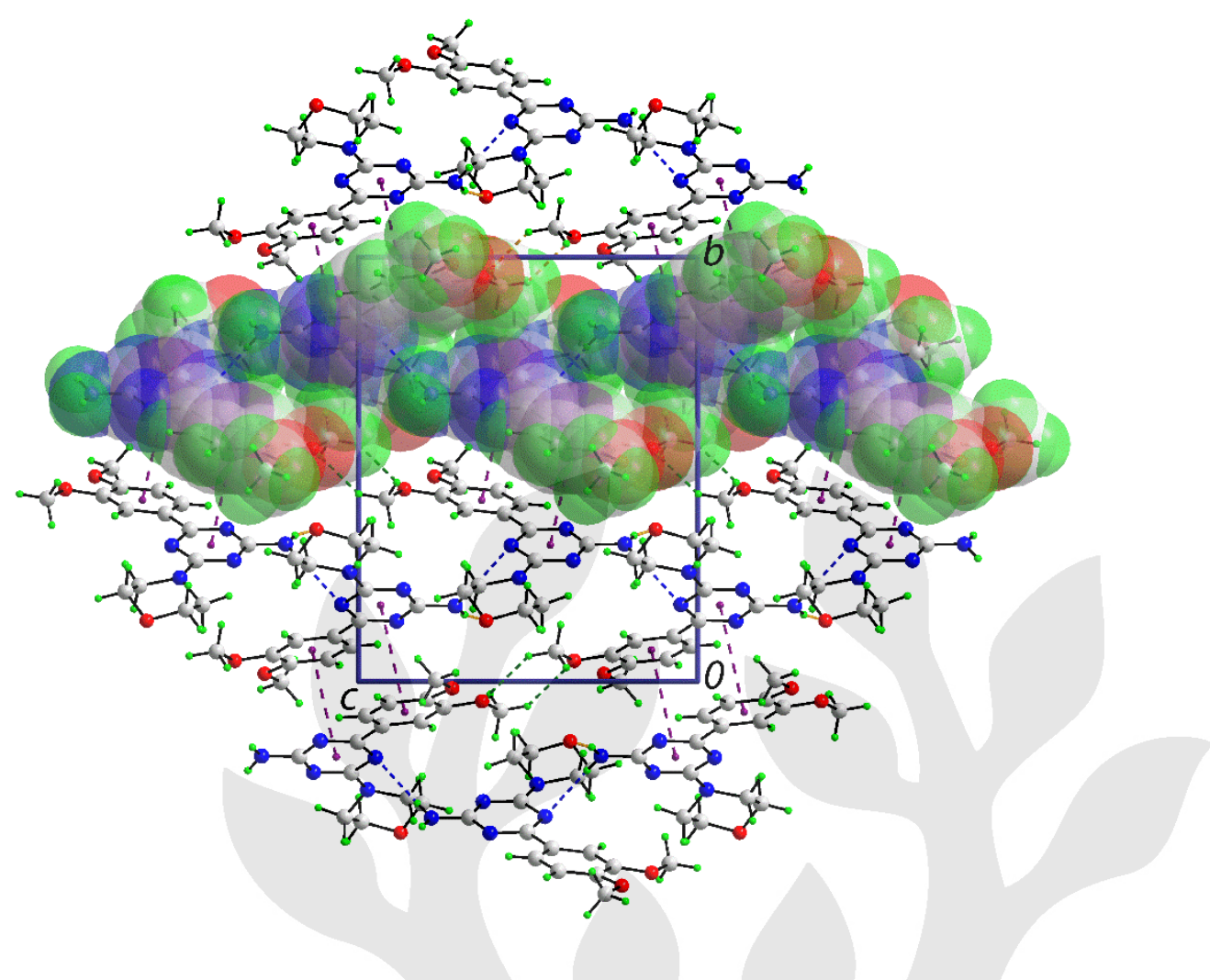

Figure S2. Molecular packing in 1n: a view in projection down the a-axis of the unit cell contents. The $\mathrm{N}-\mathrm{H} \cdots \mathrm{O}, \mathrm{N}-\mathrm{H}^{\cdots} \mathrm{N}, \mathrm{C}-\mathrm{H}^{\cdots} \mathrm{O}$, and $\pi \cdots \pi$ interactions are shown as orange, blue, green, and purple dashed lines, respectively. One supramolecular layer is highlighted in spacefilling mode.

Geometric parameters $\left(\AA,{ }^{\circ}\right)$ characterising the identified intermolecular interactions:

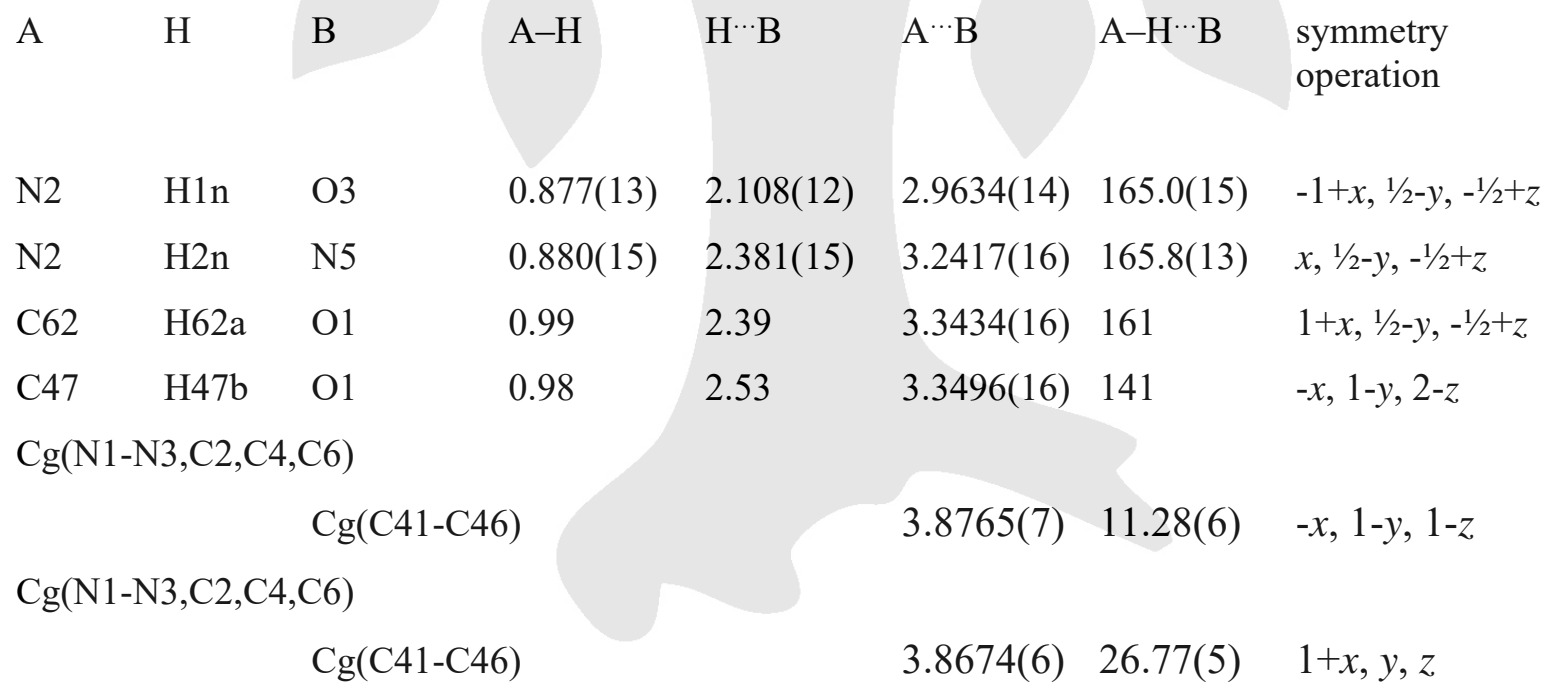




\section{Copies of ${ }^{1} \mathrm{H}$ and ${ }^{13} \mathrm{C}$ NMR spectra for prepared}

4-aryl-6-cycloamino-1,3,5-triazin-2-amines (1a-u) 


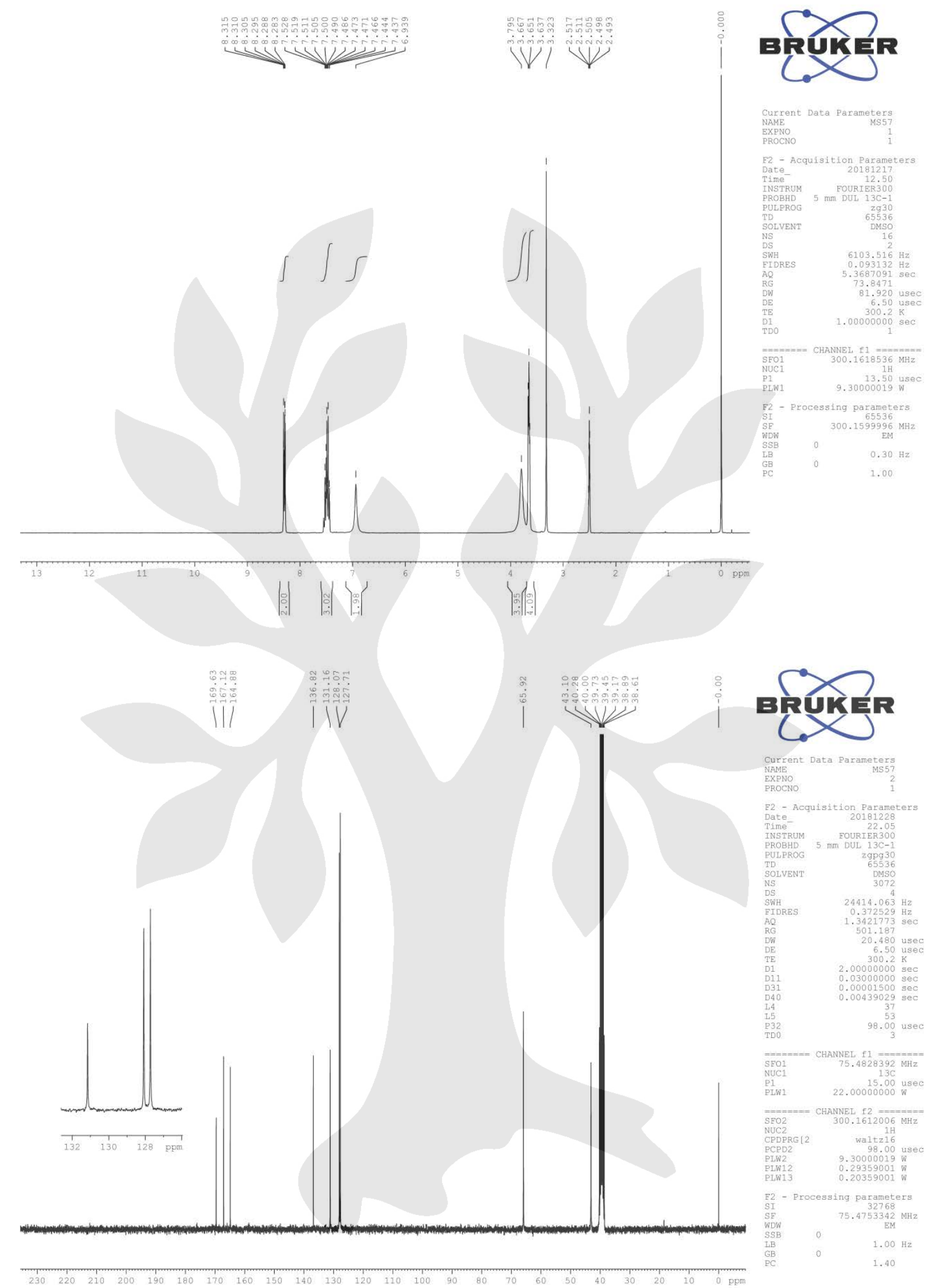




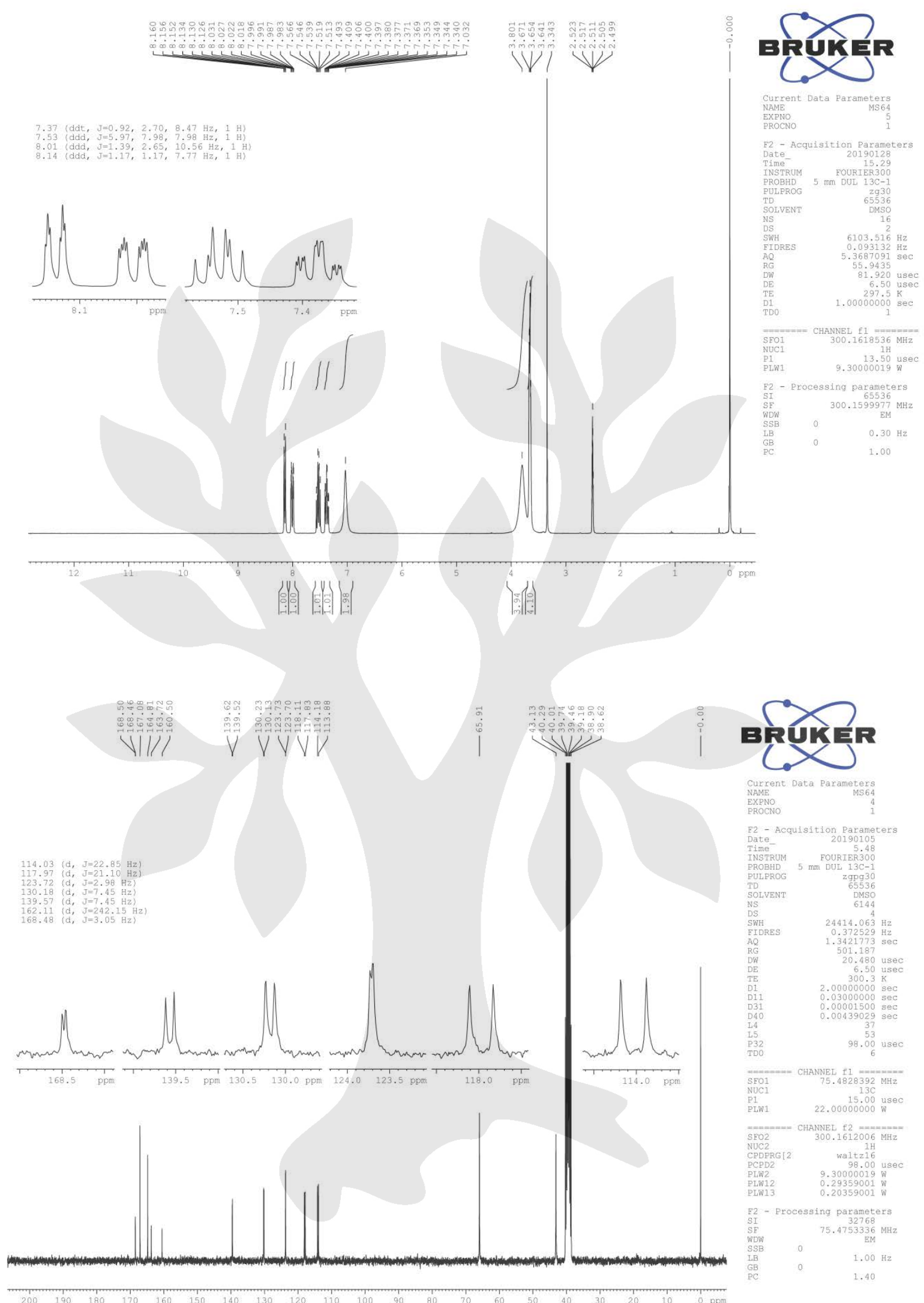




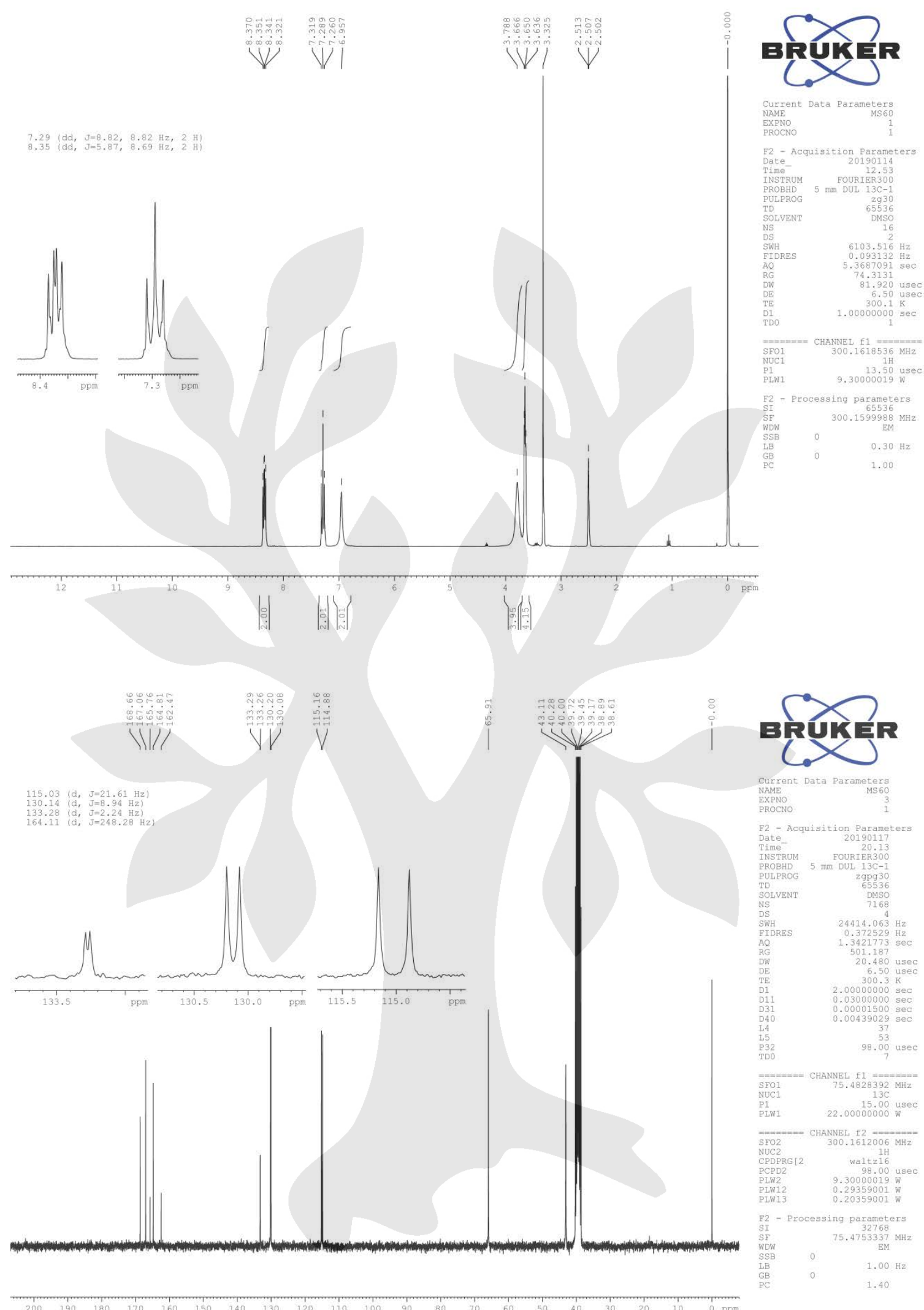




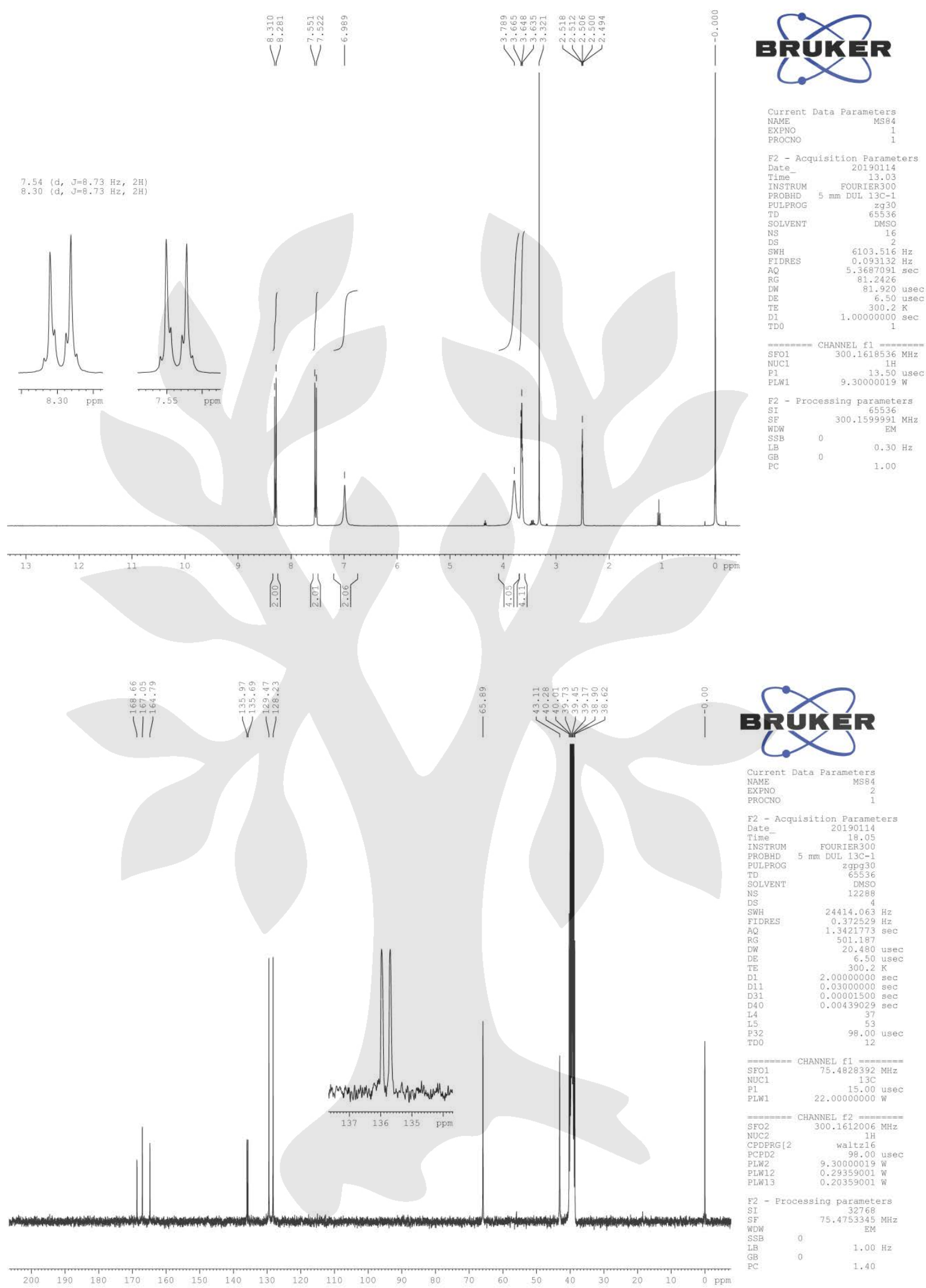


6-Morpholino-4-(3-methylphenyl)-1,3,5-triazin-2-amine (1e).

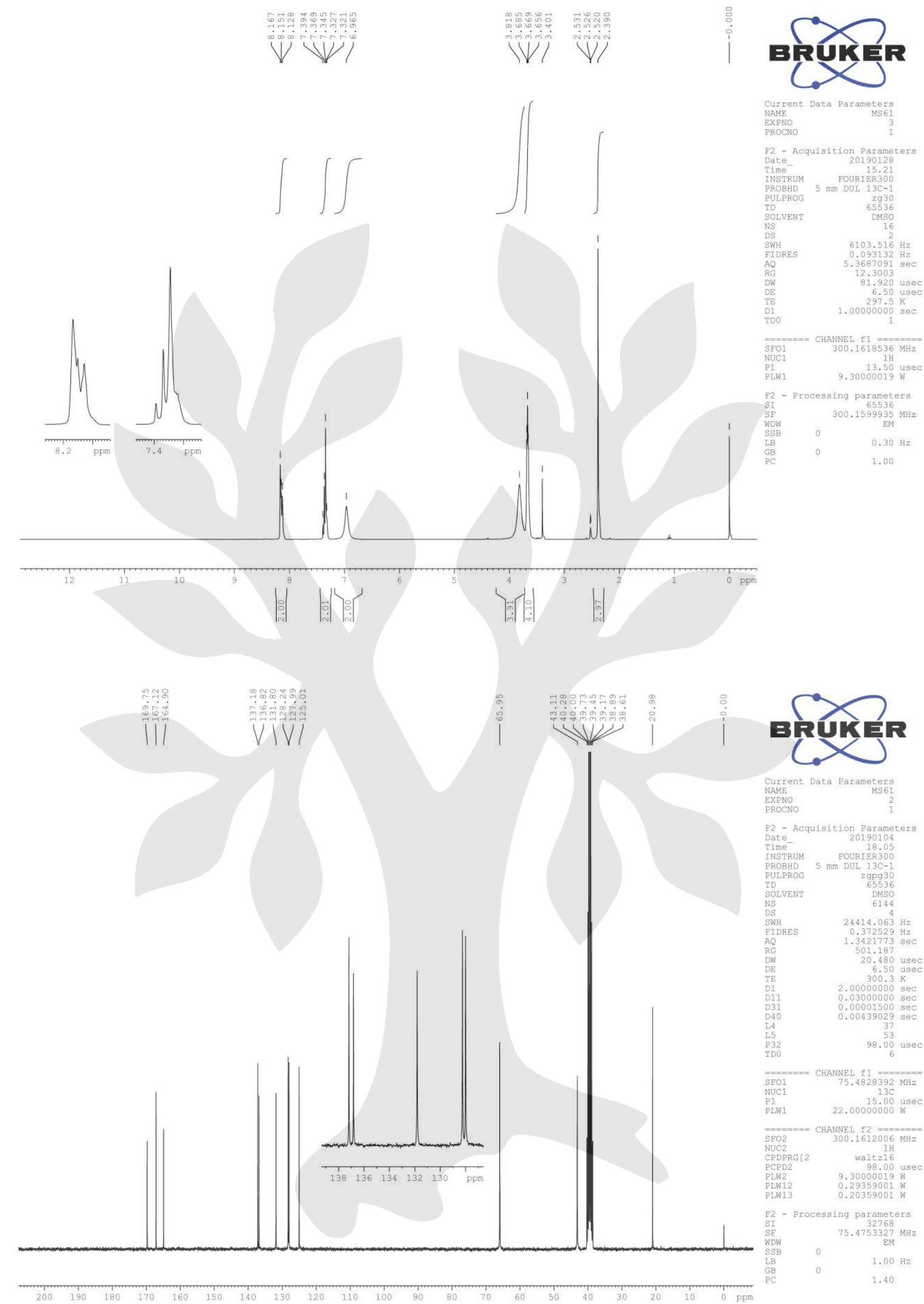




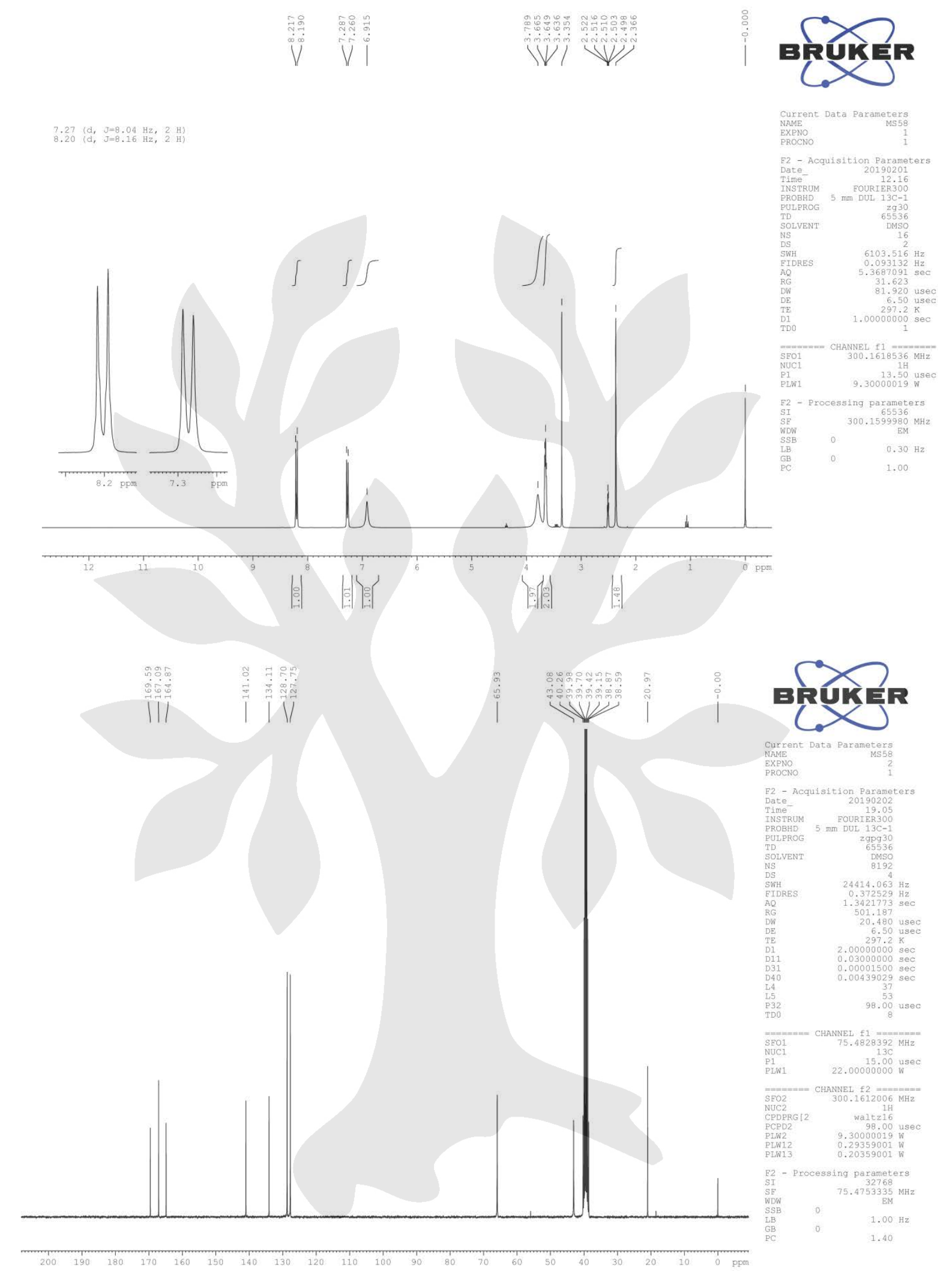




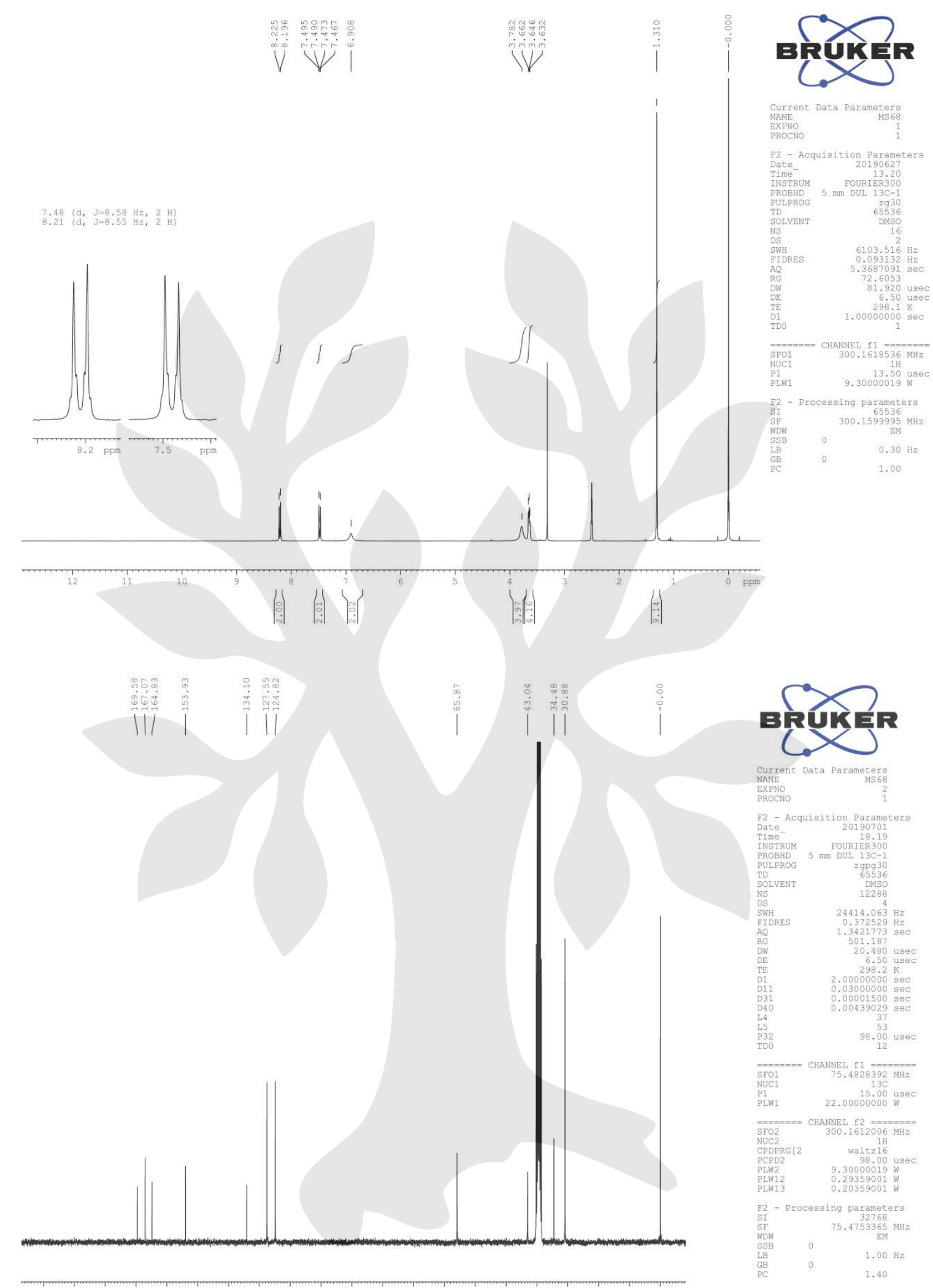




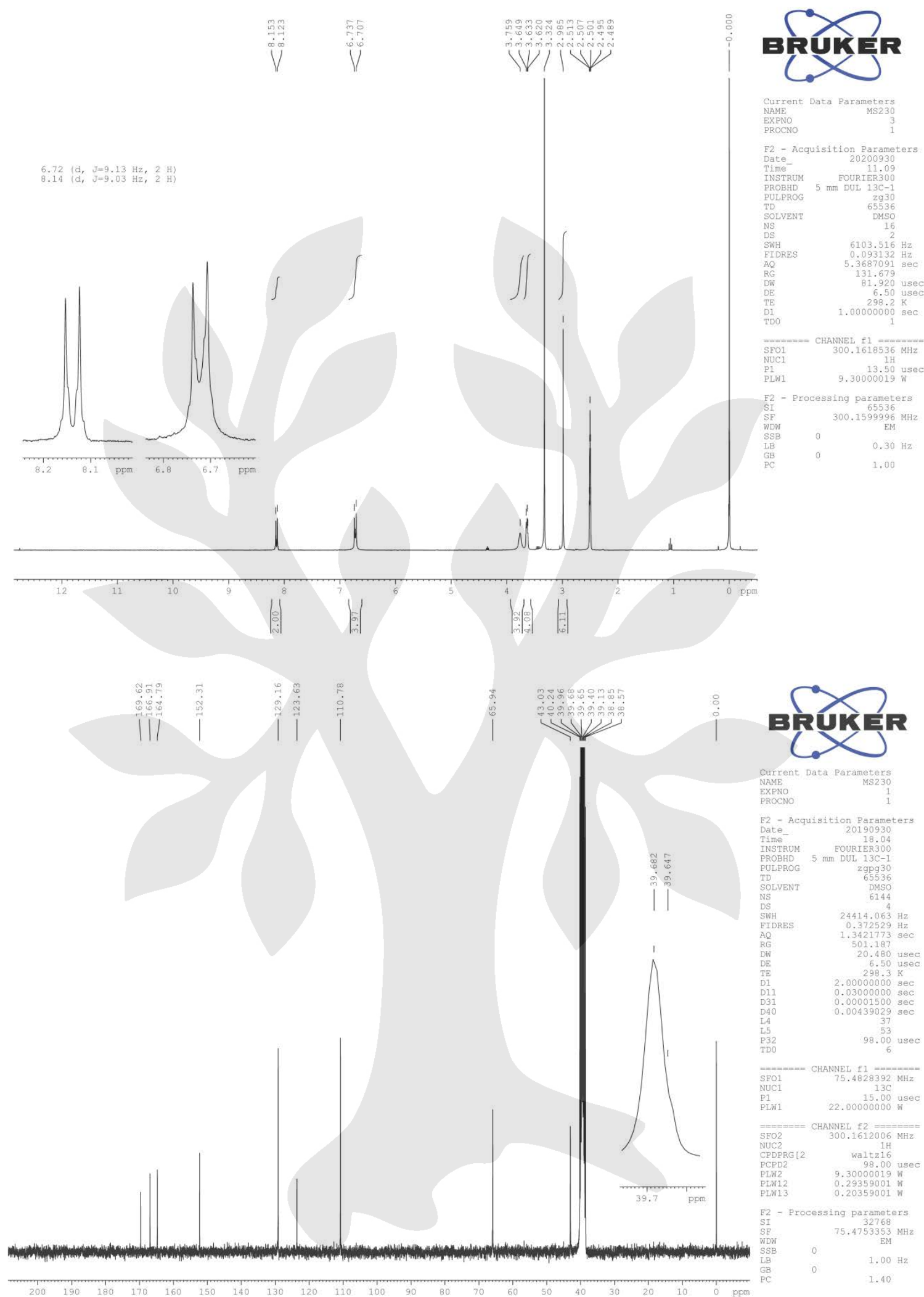




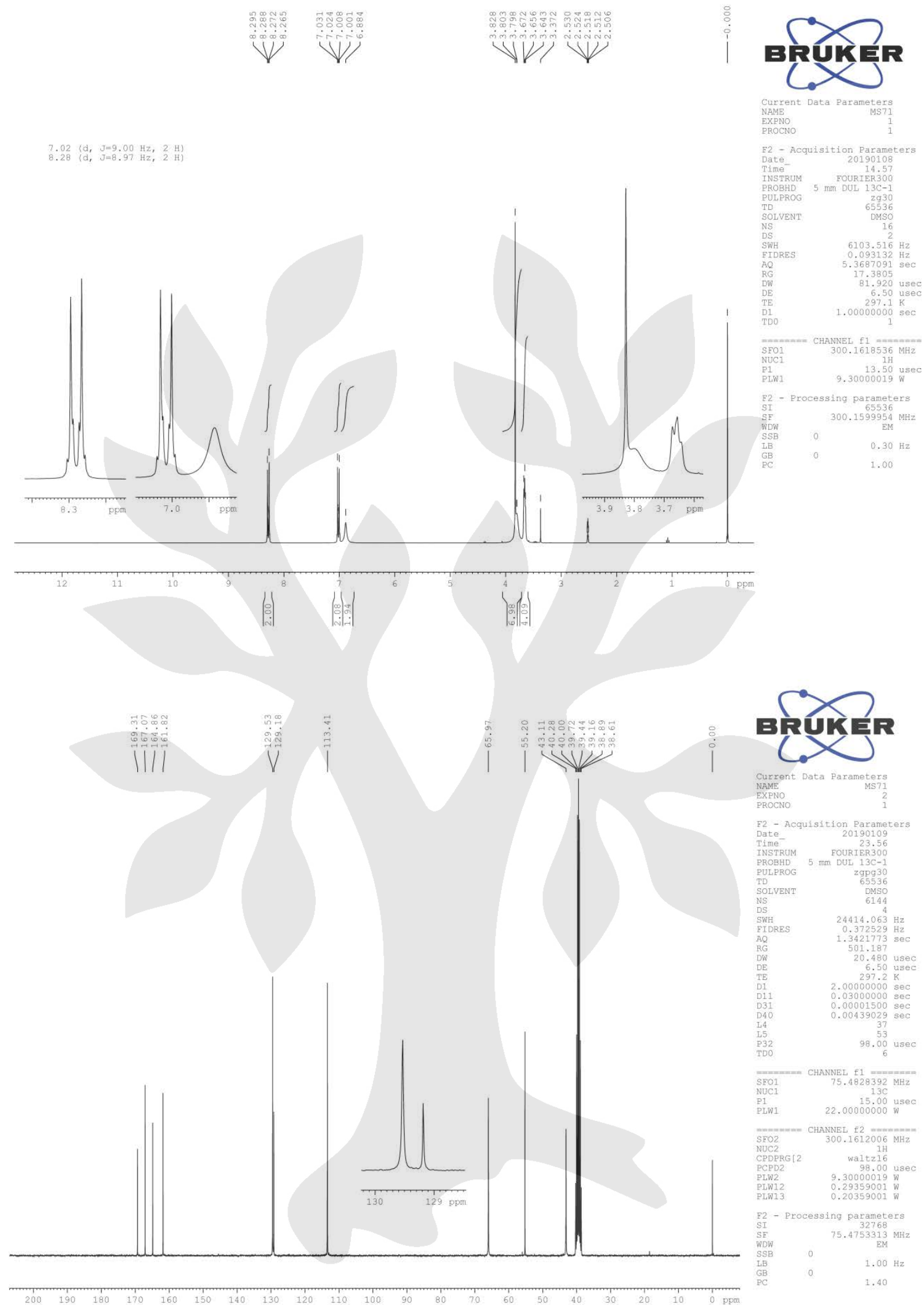




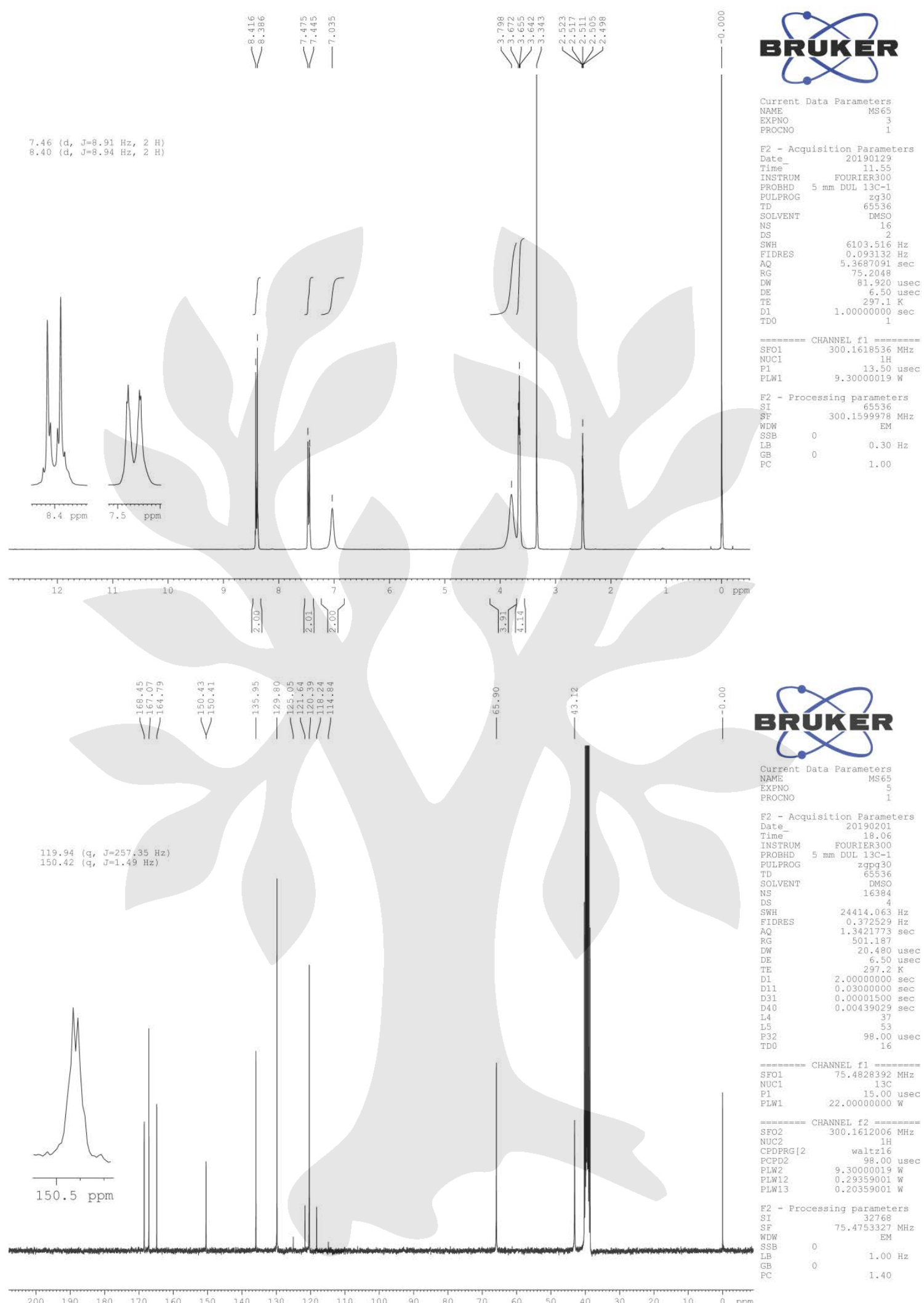




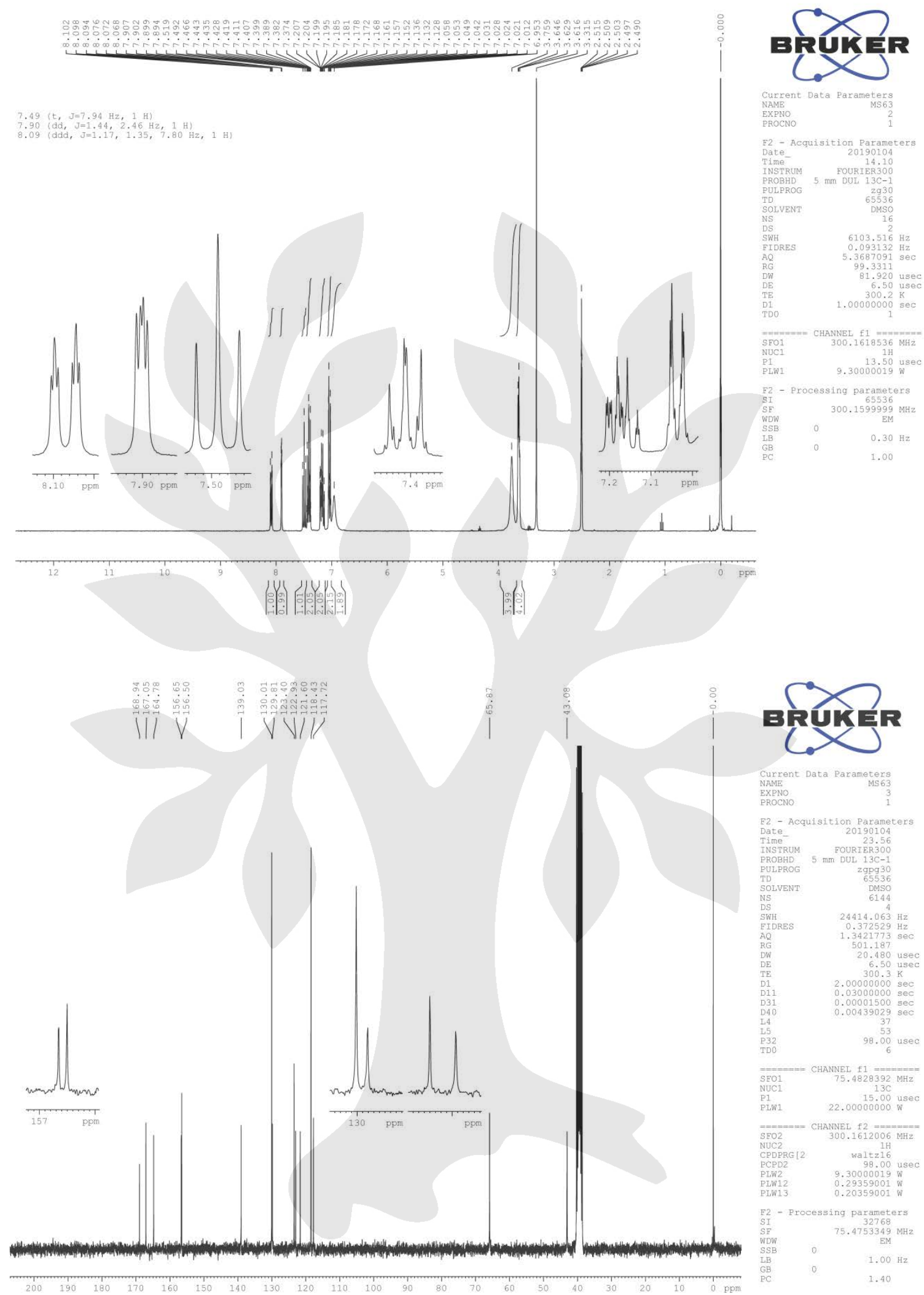




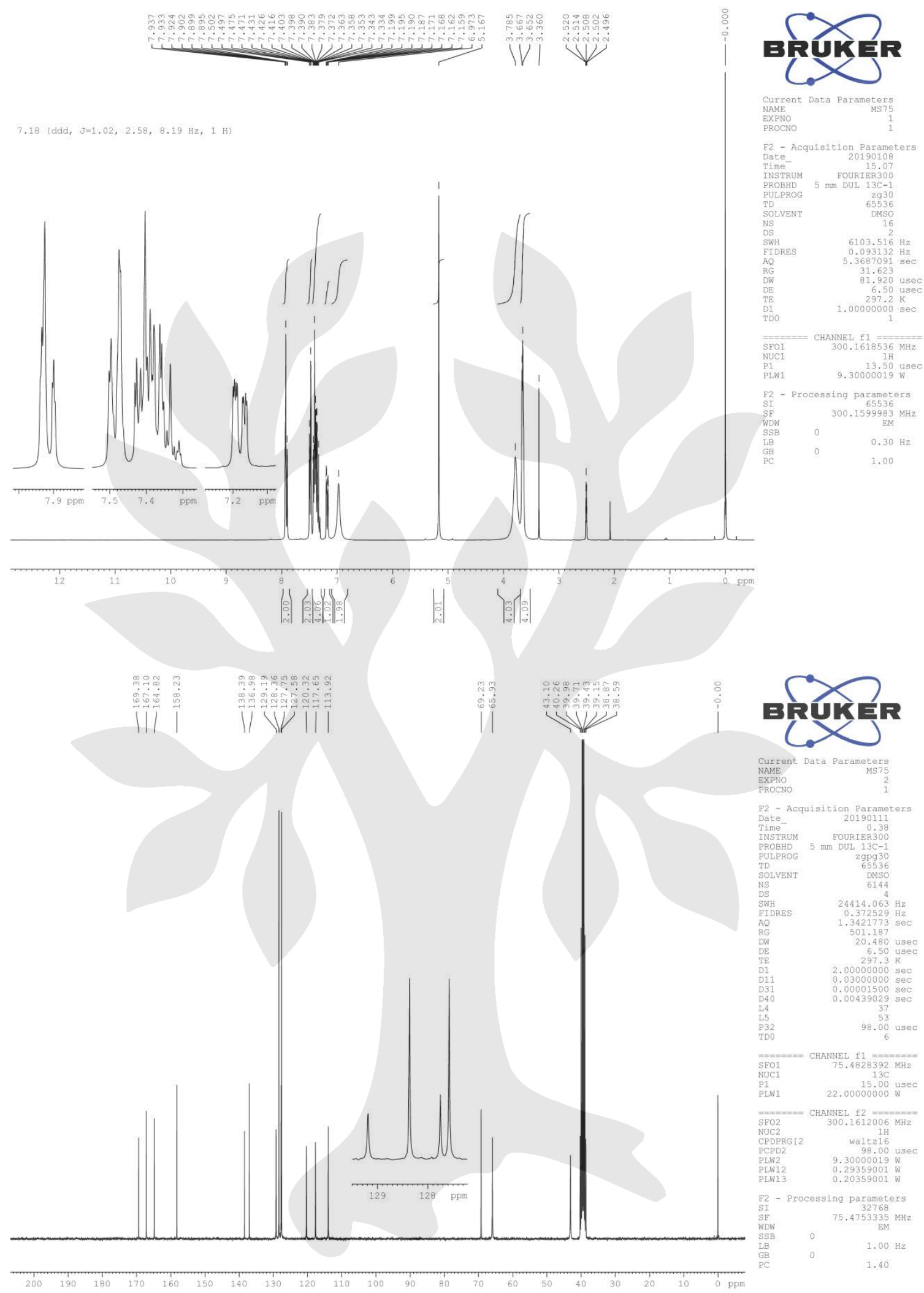




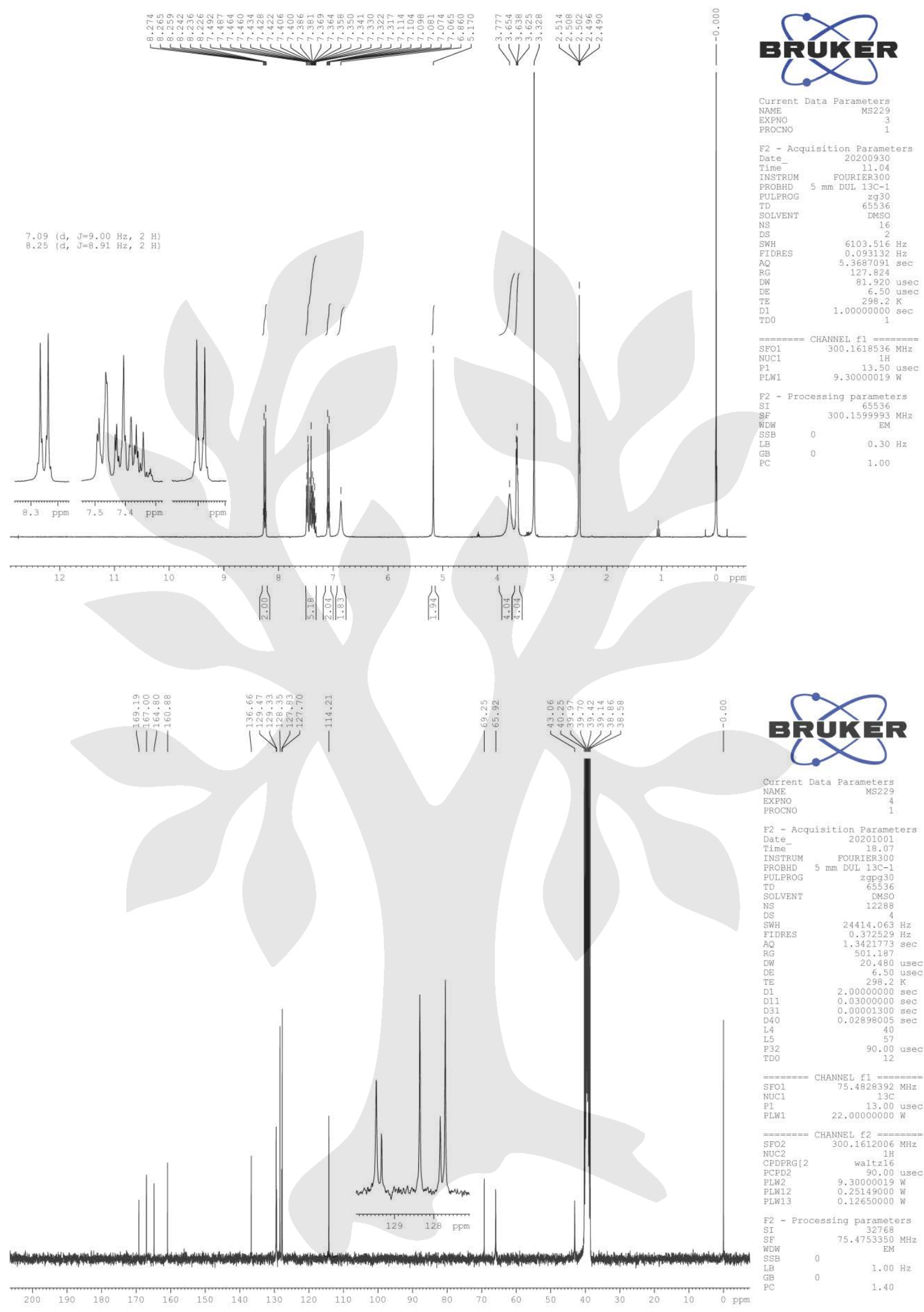




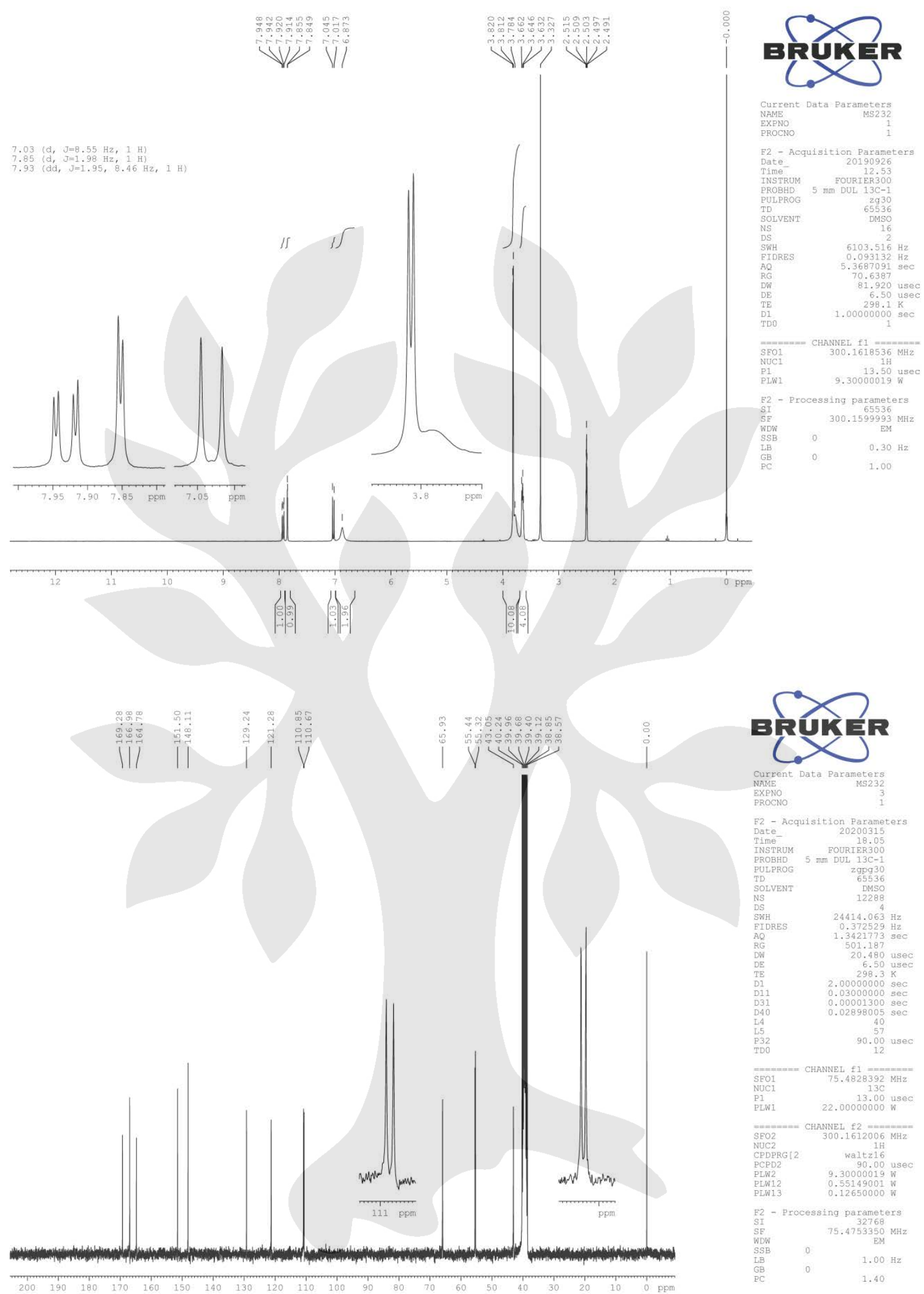


6-Morpholino-4-(3,4,5-trimethoxyphenyl)-1,3,5-triazin-2-amine (1o).

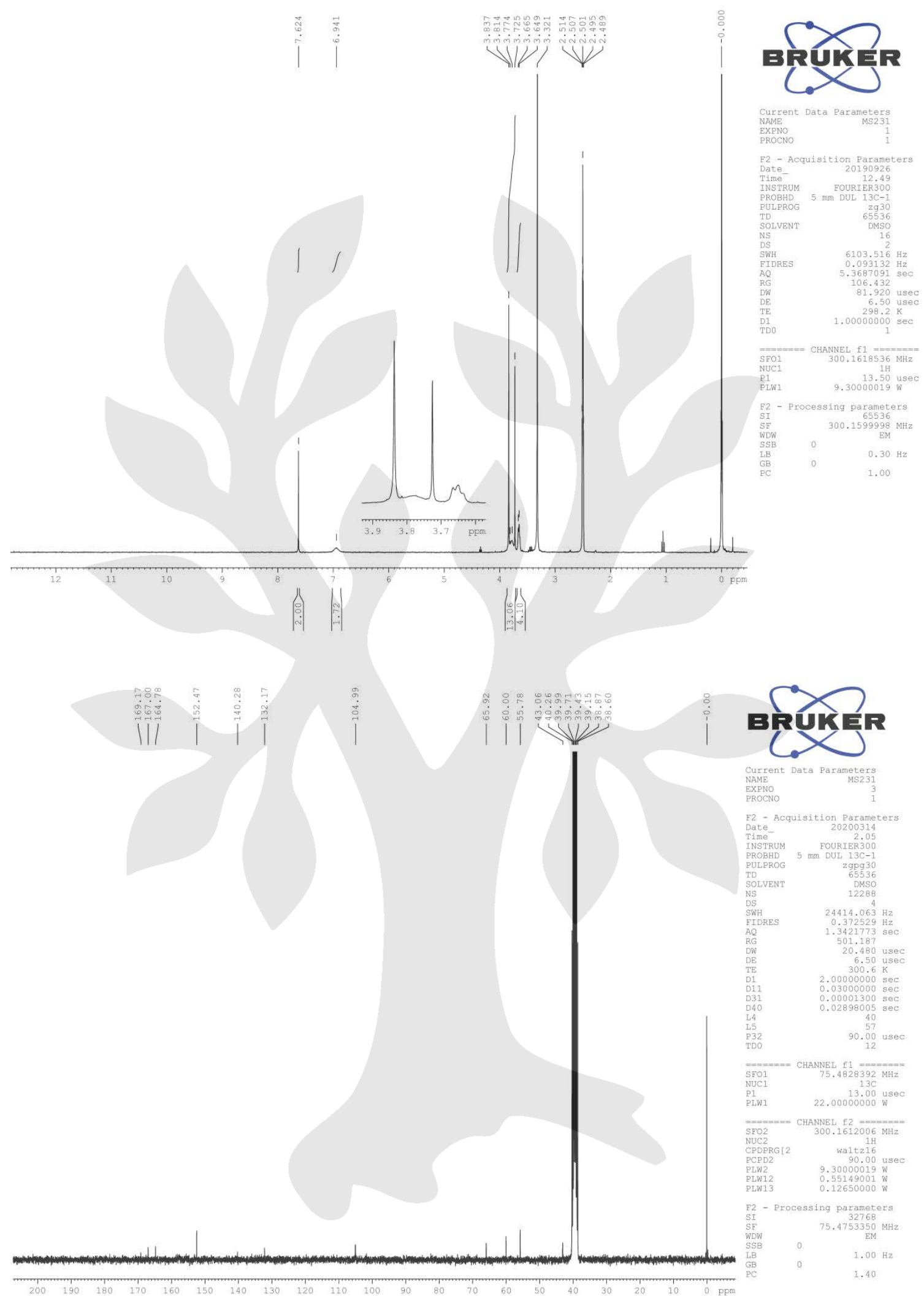


6-Morpholino-4-(thiophen-2-yl)-1,3,5-triazin-2-amine (1p).

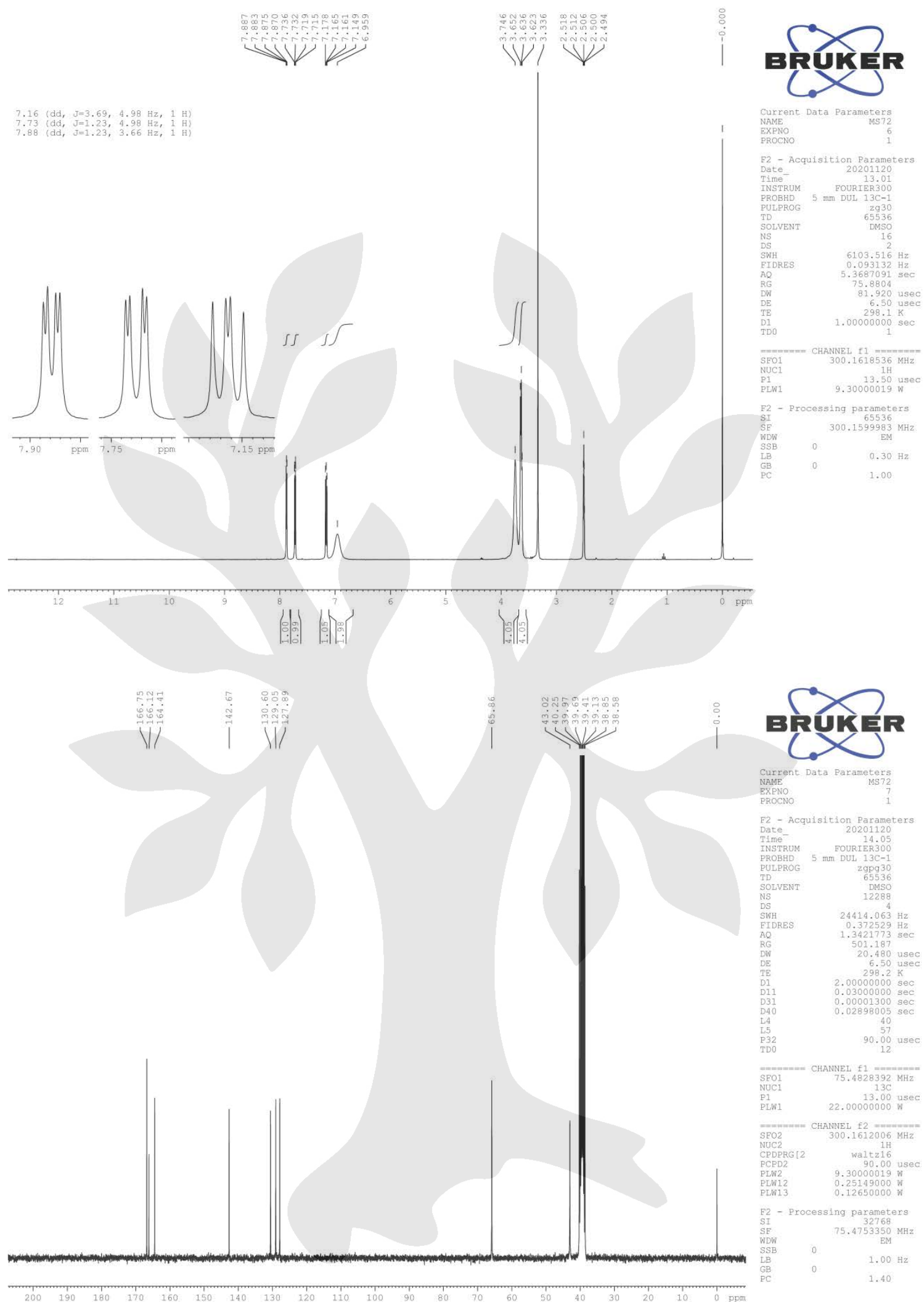




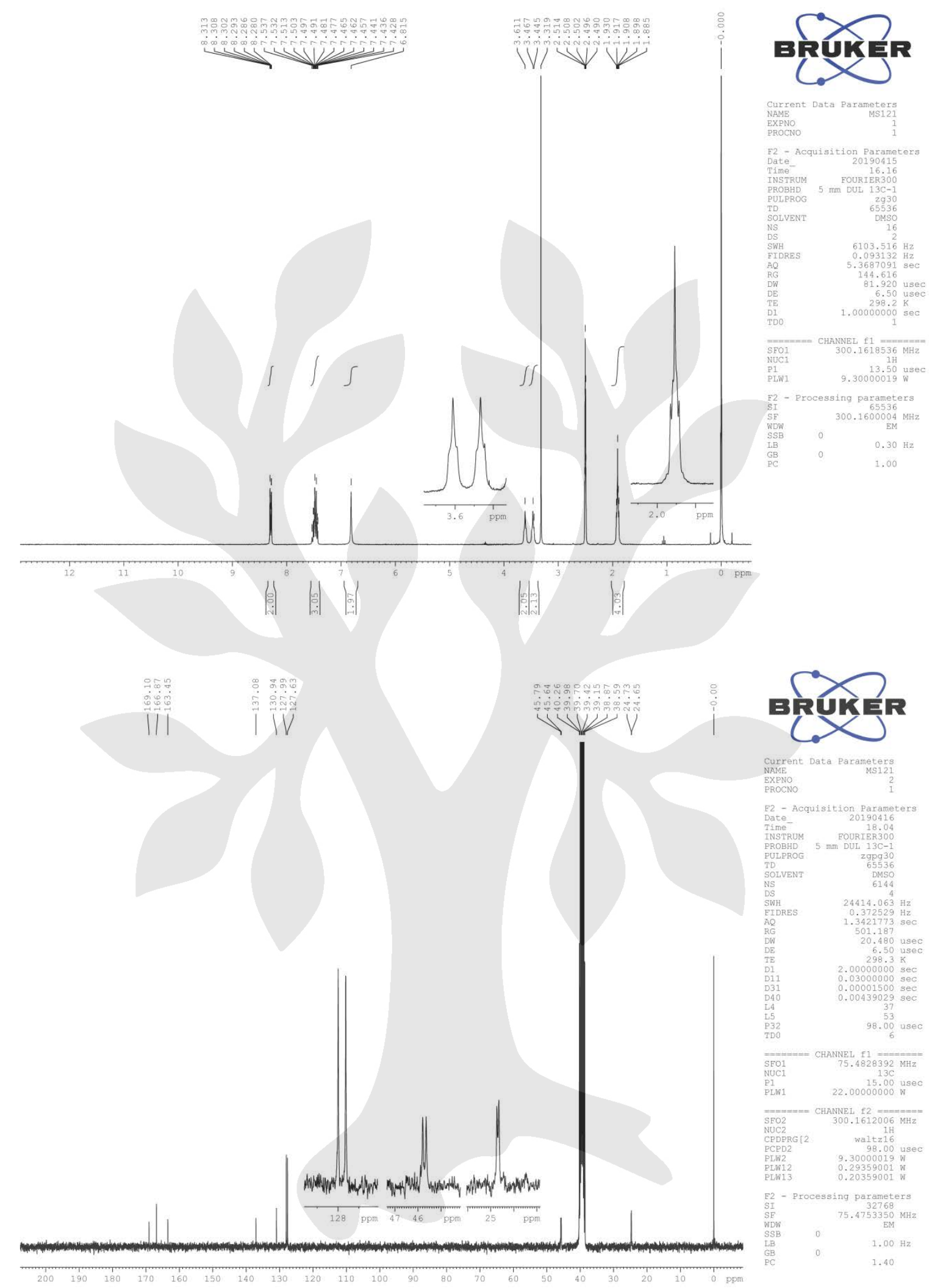




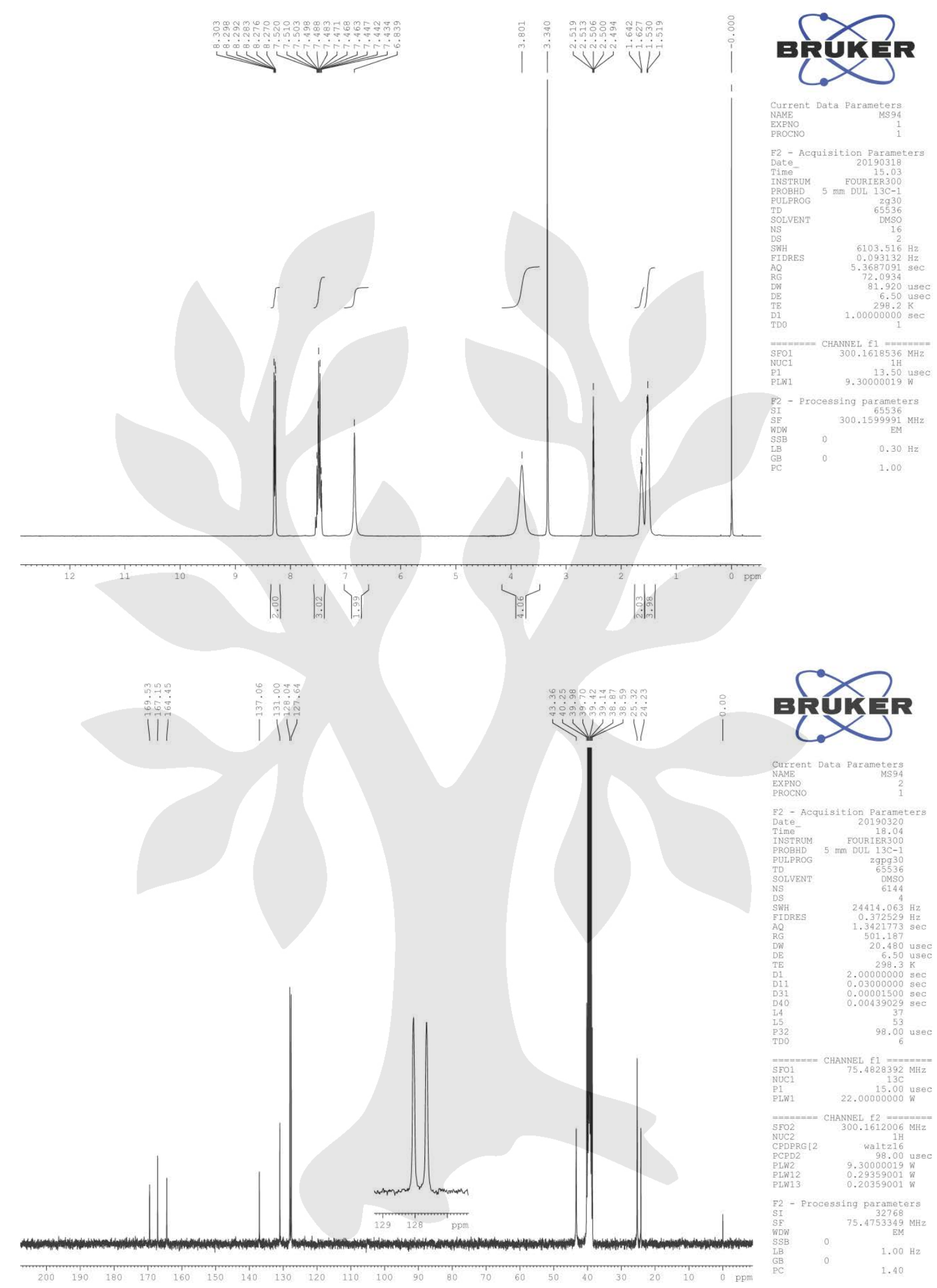




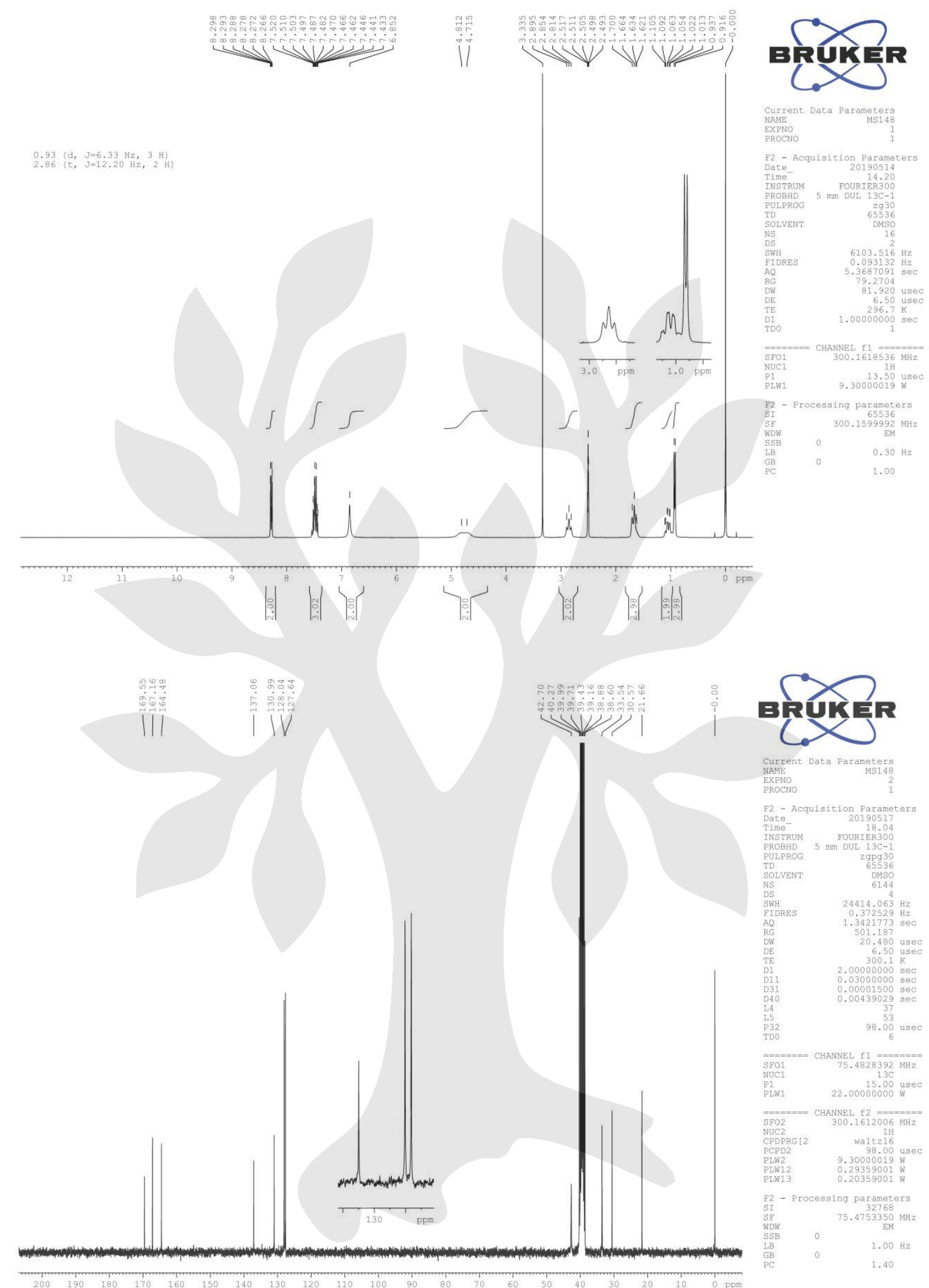


6-(4-Methylpiperazino)-4-phenyl-1,3,5-triazin-2-amine (1t).
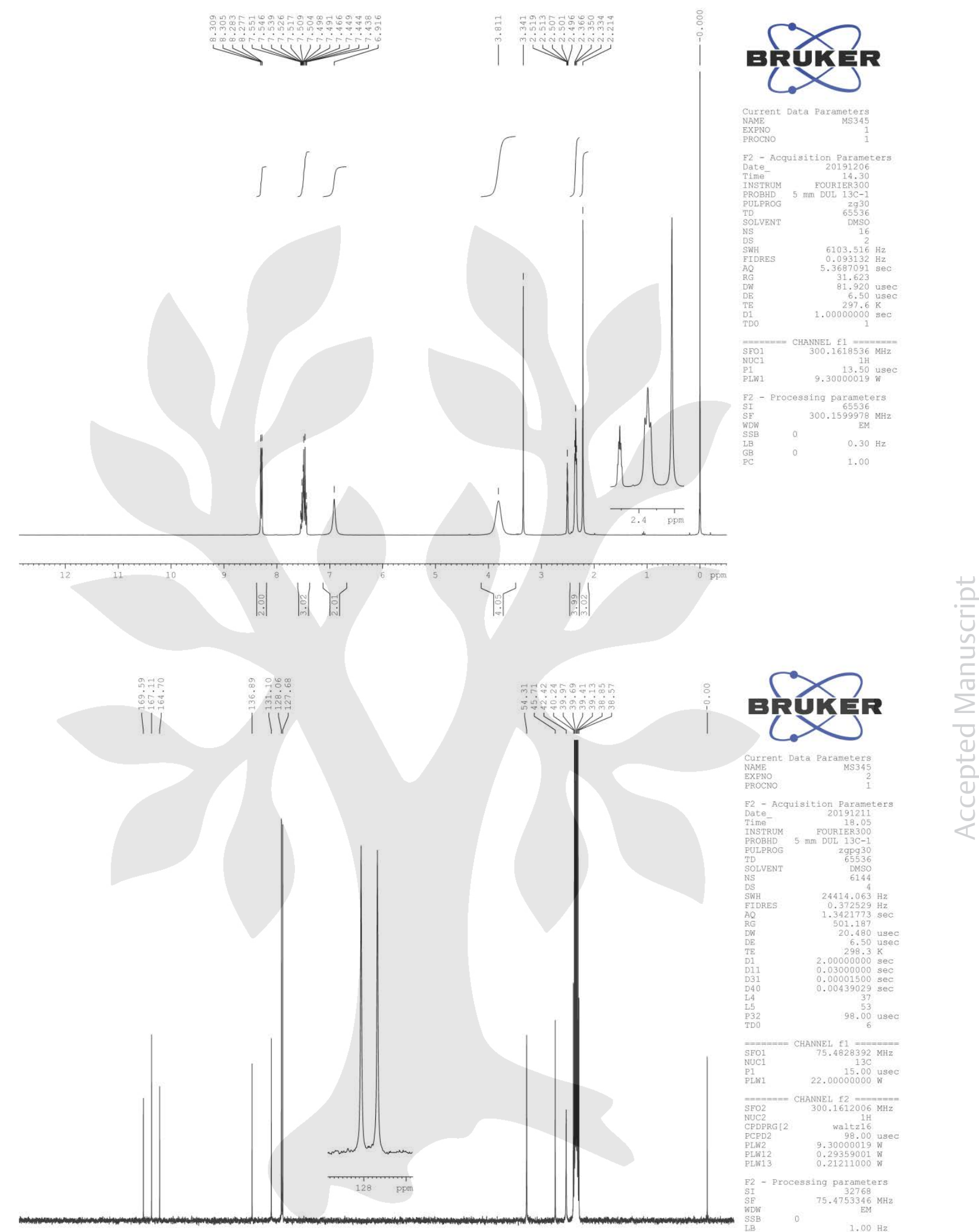
6-(3,4-Dihydroisoquinolin-2(1H)-yl)-4-phenyl-1,3,5-triazin-2-amine (1u).

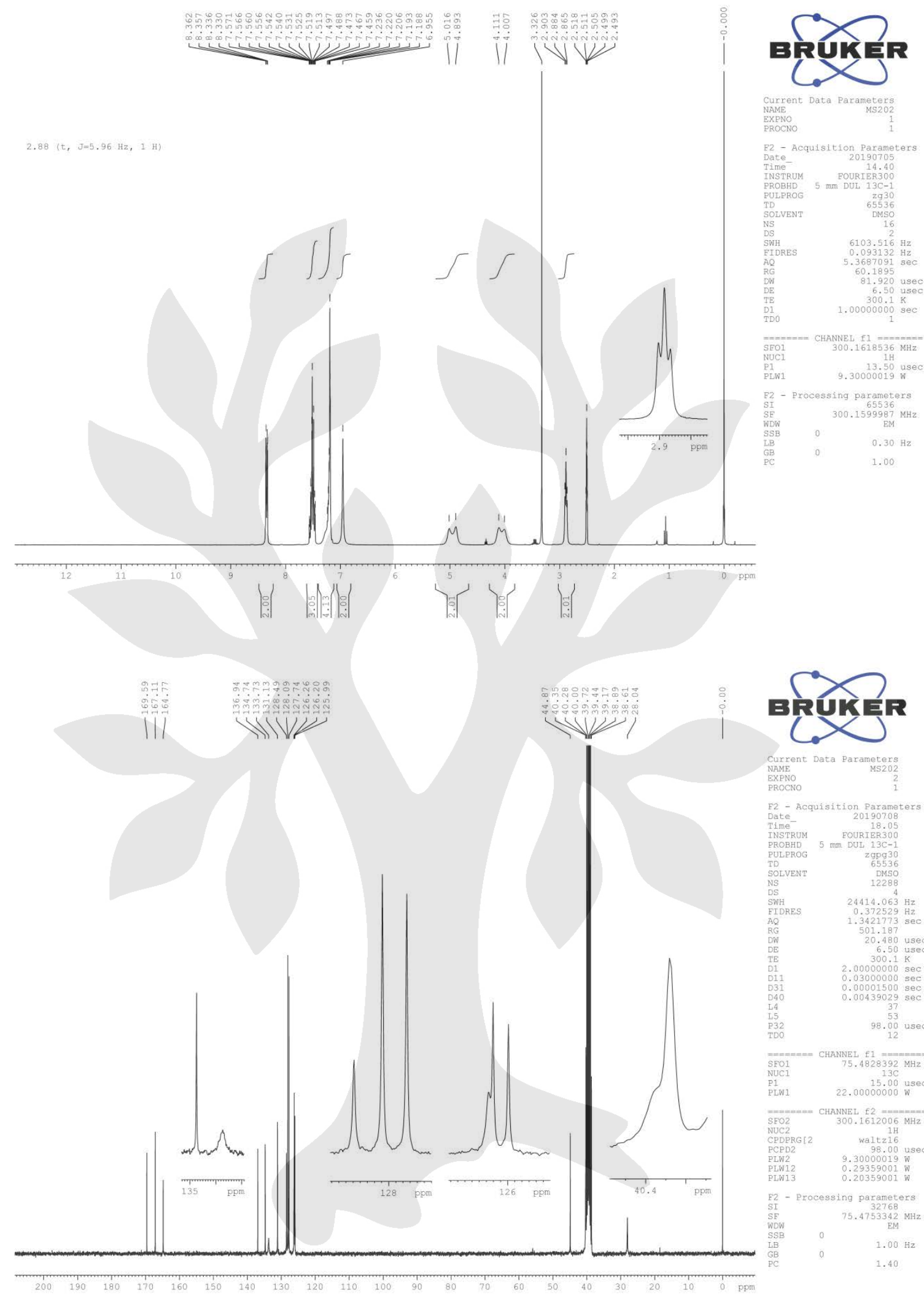




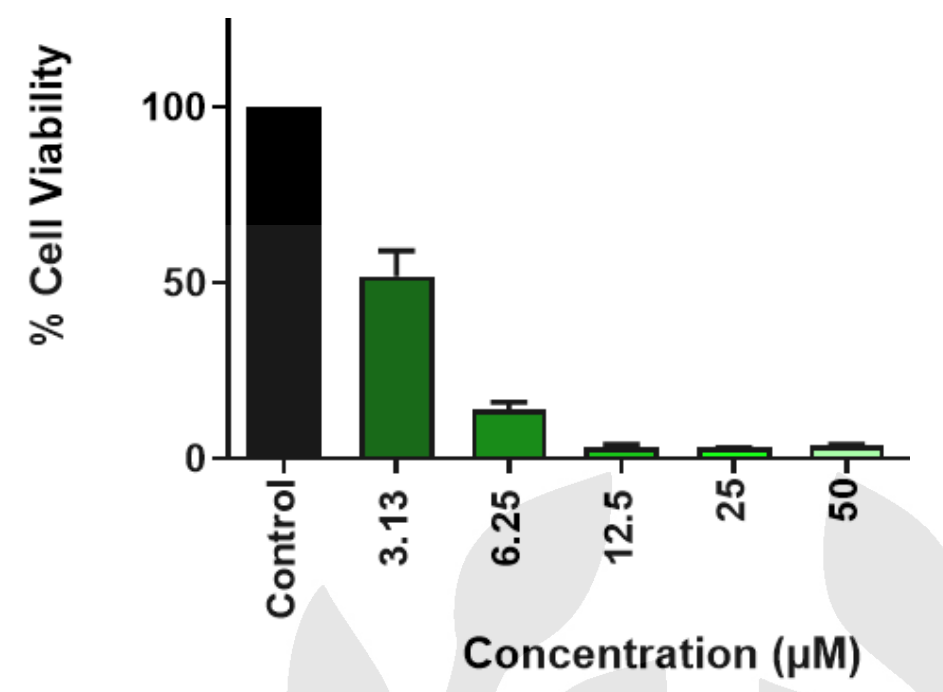

Figure S3. Concentration-dependent antiproliferative effect of $\mathbf{1} \mathbf{u}$ against Jurkat-T cells after the incubation for $72 \mathrm{~h}$. 